\title{
Occupying Cyberspace: Indonesian Cyberactivists and Occupy Wall Street
}

by

\author{
Michael Paul Oman-Reagan
}

\begin{abstract}
Submitted in partial fulfillment of the requirements for the degree of
Master of Arts in Anthropology, Department of Anthropology

Hunter College, The City University of New York
\end{abstract}

2013

Thesis Sponsor: Yukiko Koga, Hunter College, CUNY

Second Reader: William Scott, University of Pittsburgh

As the Occupy Wall Street movement went global, activists in Indonesia adopted an Occupy discourse, in part, through creation of and participation in Facebook groups. These groups afforded opportunities for Indonesian Facebook users participating in local activism online to join a globalizing Occupy movement within a familiar online activism framework. Despite a history of colonial occupation, Indonesian cyberactivists embraced expanded meanings of the word occupy as they joined a global social movement and formed local Occupy networks. During two years of multi-sited ethnographic fieldwork online and in Indonesia, this research explored what constitutes "occupation" for online participants in the Indonesian Occupy movement, and what it means for activists to "occupy" in (post) colonial Indonesia.

Key words: Activism, anthropology of cyberspace; empire; engaged anthropology; indigeneity; (post)colonialism; social movements; technology; Indonesia. 


\section{Contents}

List of Figures $\quad 3$

Acknowledgements $\quad 4$

Abbreviations $\quad 5$

Indonesian Terms $\quad 6$

INTRODUCTION $\quad 8$

PART I. EMERGENCE OF AN INDONESIAN OCCUPY MOVEMENT 19

1. Keeping Files on My Friends 19

2. From Water Buffalo to Social Media $\quad 27$

3. Re-framing "Occupation" $\quad 30$

4. Communities of Practice and Wayang 39

5. Protest Signs and Shadow Puppets 44

PART II. REFORMASI, OCCUPY AND THE RUINS OF EMPIRE $\quad 53$

6. Toward a Genealogy of the Indonesian Occupy Movement 53

7. The Rise of The New Order $\quad 56$

8. Indonesian "Ruins of Empire" $\quad 61$

9. From Reformasi to Occupy: "I was in Jakarta on May 1998 . . ." 62

10. New Order Memory and Inheritance $\quad 65$

\begin{tabular}{lr} 
Part III. OCCUPYING FREEPORT & 78 \\
\hline
\end{tabular}

$\begin{array}{ll}\text { 11. Occupying Occupied Papua } & 78\end{array}$

12. Resource Extraction and Indigenous Voice 81

\begin{tabular}{lr} 
CONCLUSION & 90 \\
\hline
\end{tabular}

\begin{tabular}{lr} 
APPENDIXES & 93 \\
\hline
\end{tabular}

A. Notes on Methods and Analysis 93

B. Theorizing an Anthropology of Cyberspace 105

C. A Brief History of Occupy and Online Activism 117

D. Selected Field Notes 127

\begin{tabular}{lr} 
BIBLIOGRAPHY & 141 \\
\hline
\end{tabular} 


\section{List of Figures}

Figure 1: Linda Hunt as Billy Kwan in his office. 20

Figure 2: At The People's Library (Library of Occupy Wall Street). 22

Figure 3: My Kiwi friend in Zucotti Park. 24

Figure 4: "All public spaces are occupy spaces, \#occupy, we are 99\%" 33

Figure 5: Unpainted Wayang Kulit Puppets at the Dalang's house. 41

Figure 6: A small Wayang Kulit performance on Mount Kawi, East Java. 42

Figure 7: A large Wayang Kulit performance on Mount Kawi, East Java. 43

Figure 8: Occupy Jakarta group profile image. 44

Figure 9: Image posted to Occupy Jakarta group wall. 45

Figure 10: Memorial image for Mas Sondang. 50

Figure 11: Nobodycorp. Occupy Jakarta poster. 52

Figure 12: Map of separatist, independence, and autonomy movements. 75

$\begin{array}{ll}\text { Figure 13: West Papua protest sign and activists. } & 78\end{array}$

Figure 14: Grasberg mine, West Papua. $\quad 82$

Figure 15: Occupier in Papuan costume with Papuan activist. 86

Figure 16: "Savages or Terrorists?” $\quad 89$ 


\section{Acknowledgements}

My thesis advisor, Dr. Yukiko Koga, was among the first to encourage this research beyond a term paper and I am grateful for her example, support and advice. Dr. Marc Edelman's encouragement has been essential to this ongoing work. I thank Dr. Barbara Sproul for reminding me of my roots in the study of religion, and for her advice to just get this done. Dr. William Scott helped me refine parts of this text while guest editing an Occupy themed issue of Critical Quarterly, and I am grateful for his further assistance as my second reader.

My heartfelt thanks to all of my informants for inspiring new questions, revealing connections, and sharing their stories. My comrades at the Occupy Wall Street People's Library and the Occupation of Liberty Plaza (Zuccotti Park) created a community from which I was able to set out and begin this project as part of the Occupy family. My love and thanks to my family and friends in New York, Oregon, and around the world, who have kept me going during these years of research.

This project would not have been possible without language training provided by the U.S. Department of State's Critical Language Scholarship Program and the Konsulat Jenderal Republik Indonesia New York (Consulate General of the Republic of Indonesia, New York). Sincere thanks also to the staff at Ohio State University and Universitas Negeri Malang for assistance with my language studies. Financial support for my work on this project was provided by grants and scholarships from:

Thomas Hunter Honors Program, Hunter College

Hunter College Foundation

Alumni Association of Hunter College

Department of Anthropology, Hunter College

Office of the Dean of the School of Arts and Sciences, Hunter College 


\section{Abbreviations}

AMAN Aliansi Masyarakat Adat Nusantara (Alliance of Indigenous Peoples of the Archipelago)

BEI Bursa Efek Indonesia, Indonesia Stock Exchange in Jakarta

BII Bank Internasional Indonesia, owned by Maybank (Malayan Banking Berhad), the largest financial group in Malaysia.

CLS Critical Language Scholarship program, U.S. Department of State

CUNY City University of New York

HNWI High Net Worth Individuals

IRC Internet Relay Chat, a text based Internet chat environment.

LGBTQ Lesbian, Gay, Bisexual, Trans, Queer, and others.

LOTR Lord of The Rings, a novel by J. R. R. Tolkein

MUD Multi-User Dungeon/Dimension/Domain: a multiplayer, networked, textbased virtual world.

MOO MUD Object Oriented: a MUD in which users can perform object oriented programming to create new objects, rooms, and experiences shared by all users.

OWS Occupy Wall Street

PKI Partai Komunis Indonesia (Indonesian Communist Party)

SDS Students for a Democratic Society

SMS Short Message Service: mobile phone text messaging.

UM Universitas Negeri Malang (State University of Malang) 


\section{Indonesian Terms}

Bahasa Indonesia The lingua franca and official national language of Indonesia.

Bapak Honorific applied to men who are older or higher in status. (Mr.)

Bu A shorter form of the Indonesian honorific "Ibu" - see Ibu.

Mas Honorific applied to men who are equal in age or status. (Mister)

Masyarakat Adat Traditional Society, used in Indonesia in ways similar to the words indigenous and aboriginal in English.

Mbak Honorific applied to women who are equal in age or status. (Miss)

Handphone Mobile telephone, abbreviated HP

Ibu Honorific applied to women who are older or higher in status. (Ms., Mrs.)

Pak A shorter form of the Indonesian honorific "Bapak" - see Bapak.

Pancasila Philosophical foundations of the independent Indonesian state set forth in the 1945 constitution.

Pulsa Mobile telephone credits for calls, SMS, and internet access.

Reformasi Literally "reforms." Usually used to refer to changes after the overthrow of Suharto's repressive government in the late 1990s.

Wayang Kulit Indonesian, specifically Javanese, shadow puppet theater. The literal meaning is "Shadow Skin" or "Leather Puppets," as the Wayang puppets are made of buffalo hide. 
Field Notes - November 1, 2013 (New York):

Reading the forward and preface to LOTR, Tolkien explains that his novel is not allegorical, but rather historical and applicable:

"But I cordially dislike allegory in all its manifestations, and always have done so since I grew old and wary enough to detect its presence. I much prefer history, true or feigned, with its varied applicability to the thought and experience of readers. I think that many confuse 'applicability' with 'allegory'; but the one resides in the freedom of the reader, and the other in the purposed domination of the author." 


\section{INTRODUCTION}

In 1965 as many as one million Indonesians were massacred when General Suharto seized power from Indonesia's first president Sukarno in a violent military coup. Those suspected of being communists or supporters of communists were rounded up, jailed, and killed. By 1998 Indonesia had been under the control of Suharto's military government for 33 years. Bu Citra, a middleaged Indonesian woman now living in North America, was in Jakarta with her American husband in May 1998 when Suharto's government began to fall. ${ }^{1}$ This is how she described that day: ${ }^{2}$

At $2 \mathrm{pm}$ we were informed that there was a riot and several students were killed by the military. I rushed back home [...] and was lucky to be able to arrive home and be with my 3 American citizen chldren.

By midnight - things were so brutal and out of control - all expatriates and chineses Indonesian were rushing to the airport to get out of the country. Every one fled the country left their property. All at the airport were willing to give what ever expensive cars they drove that way as long as they got tickets to fly out of Indonesia. Some hired privates boats and gone as soon as they can.

My condition was not better either. US Embassy sent their representative to take my American kids away from me. By American law they must take all their citizen out of the country a.s.a.p - and too bad - that their mother ( me ) is an Indonesian citizen....

3 days later at 4 a $m$ the US Embassy car picked up the children from the house - $\mathrm{i}$ was allow to go with them to the airport to say good bye.

Jakarta was in turmoil as Suharto's military dictatorship came to an end. The streets were crowded with protests, riots, and violent conflicts with police and military. Bu Citra's daughters were taken from her. She got word that activist friends of hers were killed in the streets. It was a moment of change, and of fear.

1 All informant names have been changed to aliases drawn from popular names identified through baby-naming web sites.

2 Responses from informants have been reproduced as delivered, however extra spaces have been removed. No changes have been made to punctuation, grammar or spelling. 
In another conversation Bu Citra compared Suharto's massacres in 1965 to the atrocities of World War II. However, her memory of the student protest movement in 1998 that brought an end to his dictatorship is similarly a memory of terror, loss, and tragedy. When Bu Citra encountered the Occupy movement in October 2013, memories of 1965 and 1998 were on her mind as she reached out to activists in hopes of bringing change to Indonesia again. Despite the risks, she returned to activism in order to protect her daughters and shape the future of the country she loves.

In light of her historical experience of terror accompanying radical change and activism, and in light of the colonial and imperial history of occupation in Indonesia, I wondered: what does it mean for an Indonesian ex-patriot like $\mathrm{Bu}$ Citra to reunite with activist friends and address these frightening histories? What does it mean for Indonesians to "occupy" online in the face of a violent past and the potential political and personal risks of bringing histories of activism and change into the present?

This ethnography explores these questions in three parts, each reflecting a different sense of what it means to Occupy. First, in Part I, I consider how Indonesian activists adopted Occupy as an umbrella for solidarity among existing counter-hegemonic activist groups and causes. Looking at the politico-legal situation in Indonesia and the emergence of Occupy, I examine how activists created expanded meanings of the word "occupy." Second, in Part II, I examine Occupy as a framework for reconsidering the past by asking what it means to Occupy on a site of multiple historical "occupations." Turning to movement histories and my informants' memories and biographies, I situate the Occupy movement within Indonesian histories of colonialism, imperialism, and Suharto's New Order period. Finally, in Part III, I explore Occupy as testimony. Through an examination of indigenous activism, I look at online activity around an 
ongoing struggle in West Papua, and how this online engagement works to direct attention toward national governments' complicity in neocolonial resource extraction, land theft, and threats to indigenous communities.

In addition to this ethnographic account of Indonesian Occupy in three parts, I include three essays in the Appendix. These essays explain the methods I used in this project, my theoretical approach to anthropology online, and the history of occupy and online activism. In the first essay (Appendix A), I give a detailed description of the methods and analysis used to research and write the ethnographic text. In the second essay (Appendix B) I discuss my research in terms of current literature and ethnographic approaches to studying online culture and space. Finally, in the third essay (Appendix C), I give a brief history of the Occupy Wall Street movement and Internet activism.

Through these two sections, the three-part ethnography and the three essays in the appendix, this text aims to demonstrate how social movement studies can productively engage with both critical anthropology and the anthropology of technology. By looking at continuities and ruptures between histories of movements in terms of their engagements with technology this project contributes to the anthropology of social movements and activism. This research also contributes to digital anthropology by approaching online actions as meaningful data while simultaneously examining physical action at multiple scales in order to bridge the study of digital and physical publics. This intermixing of the digital and the physical reflects the complex negotiations I found as I studied Indonesian activist adoption and reconfiguration of the Occupy discourse.

"Duduki," the Indonesian word for "occupy" means "to sit" or "sit-in," and while I found the Indonesian Occupy movement adopting localized practices and causes, they did not often use 
the Indonesian word duduki. Instead, they favored the English word Occupy. For Indonesian activists, Occupying meant more than the occupation of space, more than just sitting-in or duduki. To Occupy meant to participate in a fundamental transformation of political action, a form of politics outside the sphere of the popular street protests which became a regular occurrence in the Reformasi period (post-1998 reforms). ${ }^{3}$

Since 1998, the Indonesian government and police have allowed Indonesians to hold unpermitted, un-planned demonstrations. These parade-like protests take over city streets as participants demonstrate around populist issues such as corruption, unionization, and more recently, oil prices. There are however other, more sensitive, issues which the government does not discuss and about which few dare to demonstrate or speak about. For Indonesian occupiers, Occupying means challenging those political silences by engaging with issues such as Indonesian neocolonial occupation of West Papua; refusal of the Indonesian government to address the 1965 massacres; decreasing religious freedom and increasing religious intolerance and violence; systematic oppression of religious minorities, LGBTQ people, women, and Indonesians of Papuan descent; and rapidly expanding inequality as Indonesia becomes the largest economy in Southeast Asia.

The activists I worked with challenged these political silences by going online, to build and engage with communities through social media. Starting in the 1990s scholars began to look at uses of the internet as counter-power in Ainu campaigns against Nibutani Dam in Japan; Okinawan protests of U.S. military bases; Basque separatist web sites; Estonian and Russian environmental activist e-mail campaigns; as well as efforts in Kenya, East Timor, Burma, and China (Warf and Grimes 1997). The expansion of communication technology since the 1990s

3 In this text "Occupy" (capitalized) refers both this emergent political repertoire and the social movements, while "occupy" (lower-case) retains the traditional, contextual meanings. 
has facilitated the emergence of these online social movements and connected political activists on a global scale but it has also changed local forms of political engagement. More recent scholarship has outgrown the novelty of online activism in favor of nuanced analysis. In one especially relevant example, Guobin Yang looks at online activism in China as a new form of activism that asks questions about the relations of repertoires, images, symbols, rhetoric and rituals to social and political conditions (Yang 2009). As Yang saw in Chinese online activists, I found Indonesian Occupiers skillfully navigating the Internet to engage in a creative activism shaped by a milieu of government control but not limited by that control.

The period from the 1990s to the present saw a significant change in the political and technological landscape of Indonesia. As Barker (n.d.) notes, the Internet era "marks one of the few moments in modern Indonesian history when the state has not taken a leading role in shaping techno-political imaginaries." Within this historical frame it is important to ask: In the absence of the state, who is taking a leading role, and in what ways? By looking at the emergence of the Indonesian Occupy movement this ethnography explores how online Indonesian activist "cultures of contention" (Yang 2009) engage with historical, political, and technological landscapes in Indonesia.

To the best of my knowledge this is the first ethnographic work on the Indonesian Occupy movement (online or offline). I aim to present both a record of my process of getting to know online Indonesian activists through participant-observation, as well as the stories of those people who were generous enough to speak to me about their experiences, thoughts, feelings, and memories. On the one hand this work is therefore shallow in both temporal and experiential scope; I make no claims to completeness nor to having done a scientific study based on a research plan determined in advance and carried out methodically. On the other hand, and more 
productively, I have followed connections into places I never expected and thereby written about key issues for Indonesian activists; especially around the network of connections from Wall Street in New York City across the globe to neocolonial resource extraction in West Papua. Following Anna Tsing, I have sought the "odd connections rather than seamless generalizations, inclusive tables, or comparative grids" (Tsing 2005:xi).

As I began writing this Introduction, I had recently returned from two months living in East Java where I studied Bahasa Indonesia, the lingua franca of the Indonesian archipelago. Although I started fieldwork with the Indonesian Occupy movement in the fall of 2011, the summer of 2013 was my first physical visit to Indonesia. Prior to that I conducted all of my fieldwork online, in cyberspace - performing what has been called "virtual anthropology" or "the ethnography of virtual worlds" (Boellstorff 2008:65) and what I call the anthropology of cyberspace.

My summer in Indonesia was devoted to learning Bahasa Indonesia while living in Malang, East Java on a U.S. State Department Critical Languages Scholarship (CLS) grant, and was not intended for traditional fieldwork. In fact my visa (granted by the Republic of Indonesia) and the terms of the CLS program both prohibited me from conducting formal research while in Indonesia. This is primarily because of the tight control maintained by the Indonesian government over which research is permitted within their borders and the complex application and approval procedures in place to ensure research topics are politically acceptable. My topic is not especially politically friendly to the Indonesian government of the 2010s, and as such continuing this project while living in Indonesia required improvisation.

My research remained at the forefront of my mind as I spent the summer living in Indonesia and attending intensive language courses at Universitas Negeri Malang (UM). I 
continued to conduct research in cyberspace just as I had in New York, while informing that online work with my experiences, encounters, and reflections in and of Indonesia's physical and cultural spaces. The challenges of doing research under the radar were added to the host of complications and benefits that come with online methods of ethnographic fieldwork. Although there was nothing covert about my work, I was careful to avoid taboo or forbidden topics except in private conversations with my closest friends. However, at the conclusion of the summer I presented some of my research on the Indonesian Occupy movement to a hall of students and faculty at UM. I chose my topic and presentation content contrary to explicit instructions from the Faculty of Languages at UM instructing students to avoid political, religious, or other sensitive areas, and so they bear no responsibility for the nature of my research topic or presentation that day. They did, however, ask if I was working for the CIA. It was a joke, but also not entirely. I am happy to report, as I did to the Faculty at UM, that despite my stay in Indonesia being funded by George W. Bush's 2006 "National Security Language Initiative” I was not working for the U.S. government; rather, I was Occupying.

In 2011, as I worked in the People's Library at Occupy Wall Street (in the midst of great skepticism about the usefulness of the movement and especially its online components) I began to wonder how the Occupy discourse was spreading outside of New York and outside of the United States. The story told here reflects what I found after I learned there was an Occupy movement online in Indonesia, and follows my investigations into that movement, my choice to focus this research on the online Indonesian Occupy movement, my decision to begin studying the Indonesian language, and later my travel and study in Indonesia. Each of these choices, along with other small and often invisible decisions, led to what I encountered along the way. It is that journey which serves as a backbone for the story I tell here about the Indonesian Occupy 
movement and its engagements online. My personal narrative is under the surface of this ethnography, informing the structure and form from underneath. It is after all a backbone not an exoskeleton.

I preface this introduction with a quote from J. R. R. Tolkien in which he responds to reader's questions about whether his epic fantasy stories were written as an allegory for World Wars I and II and international relations of the time. He replies by saying no - the stories are not allegorical, but that does not mean they cannot be applied to understanding and interpreting historical events. When I do not provide answers or conclusions in this text, and when I pose questions without answering them, it is because I want to maintain what Tolkien calls "the freedom of the reader" to apply and understand what I have written (2004:xxiv). This is a collaboratively produced history of some part of the Indonesian Occupy movement, and it may be applicable to other online engagements, or other social movements - but it is not allegorical. Rather it is historical (these are the things that I and others experienced) and simultaneously directly political (this is what I and others think about those experiences).

James Clifford's writing on ethnographic authority (1988:21-54) inspired my effort to preserve the voices of my informants. Following Clifford, I work against replacing informants' voices with the monophonic authority of the ethnographer. I attempt to employ several of Clifford's suggested techniques for retaining polyvocality including: discursive dialogues, extensive quotation from informants, and self-reflexive discussion of my positionality. Clifford focuses on the problem of a controlling mode of authority within the ethnographic work, and provides suggestions that I attempt to apply. Inspired by Clifford's discussions, critiques, and writing practices, I present my informant's words as they were received, without changing them into Standard English. 
I do this fully aware of the danger that unedited quotes may be perceived as an attempt to make the quotes look like "raw data" and thereby imply that to disagree with my conclusion is to suggest the voices of my informants are wrong (Boellstorff 2008:85). However, I do not intend that here. My conclusions should be judged on their own, apart from the voices of my informants whose words serve as examples and inspiration for my analysis, not proof. I do not, however, want to obscure the source of the quotes, nor privilege any one form of English over the multiple other forms which one of my informants in Indonesia taught me are called: Global Englishes. Despite being reproduced as they were written, the quotes from my informants are still edited. Because they are excerpts, they are filtered and translated from one context into another - I also make no claim to presenting an objective truth or unbiased account by sharing 'raw data.'

The majority of my field notes were transformed from their original form (as notes typed on my laptop or written in pocket sized notebooks) into the text of this ethnography. Some of the notes that were not incorporated into the main text are included throughout as field note asides. These asides are intended to provide context for my frame of mind throughout the research and writing process, to reveal some of the influences underlying my analysis, and to tie analysis to broader connections. Where they occur, the asides are marked by two dashes (--), the text is indented, full-justified, and italicized to distinguish it from block quotes. The asides are labeled "Field Notes" and the original notes they were excerpted from are included chronologically in Appendix $B$ for reference.

I was inspired to include these excerpted field notes by James Clifford's chapter "Identity in Mashpee" (Clifford 1988). Clifford's reflections in that chapter hold true for this work: "the reality presented here is the reality of a specific interest and field of vision" - and like Clifford I am mistrustful of "transparent" accounts in which the story becomes so seemingly real that the 
reader forgets about the author and the limits of the authors experience, ability, and authority (Clifford 1988:291). I hope that by including these field notes, as well as through other techniques, I have in some part avoided the "imposition of coherence on an unruly textual process" (Clifford 1988:54).

Clifford was not the first to write about these issues of subjectivity, reflexivity, and authorial voice and he was not the last. He was, however, the first author I read on the subject and his work stays with me and influences me, which is why I cite him here. The same is true of many of the authors and ideas I cite in this work. They are not the first, only, or best scholars to cite - rather, they are those whose work I have come across in my research and whose ideas resonated for me. In many cases I read their work because they were assigned in a class or seminar or shared by colleagues, professors, adjuncts, friends, and fellow students.

While revising this introduction in November 2013, I received a new issue of the journal of the Society for Cultural Anthropology. As I read the first article I found further ideas that resonated with what I had been trying to articulate here. In "Ethnography in the Way of Theory" João Biehl makes a case for "allowing our engagement with Others to determine the course of our thinking about them" and asks: "how can we ethnographically apprehend these worldy fabrications and the lives therein, constituted as they are by that which is unresolved, and bring this unfinishedness into our storytelling?" (Biehl 2013:594,574). Biehl argues that as ethnographic realities find their way into theoretical work, they do not need to be subsumed into a "proto-philosophy" but can retain their strength as ethnographic engagements to which we can continually return and learn something new. I agree with Biehl that the strength of ethnographic work is how it resists "synthetic ends" and makes "openings rather than absolute truths" in order 
to allow "for an emancipatory reflexivity and for a more empowering critique of the rationalities, interventions, and moral issues of our times" (2013:575).

The kind of "critical anthropology" (Marcus 1999) I set out to do, an anthropology concerned with ethnographies of "complex, emergent, and contemporary sites" which "evade bounded or ontologically realist demarcation" is "often pitted against, or seen as opposed to, public, activist, or engaged anthropology" (Osterweil 2013:599). However this research project is both participant-observation and observant participation. And so, in this work I have answered Osterweil's call and merged critical anthropology with an engaged anthropology of social movements while adding ethnography of online action to build an anthropology of cyberspace.

My involvement as an activist in Occupy led to my engagement as an anthropologist. When I first began to ask why Indonesians were joining Occupy Facebook groups, I found that the destruction of indigenous lands by a U.S.-based resource extraction corporation could be traced back to Wall Street, to the same corporate corruption OWS is fighting. By looking at these global links, cycles, and entanglements, I hope to trace the connections that produce inequality. In this text I turn my ethnographic focus to the engagements of Indonesian activists in order to complicate the apparent naturalness of inequality, unjust distribution, oppression, and suffering and try to understand the structures underlying these injustices. By making these structures visible, I hope to show how they might be dismantled, re-built, or changed and thereby made more just. I therefore write this in solidarity with the activists I have met, studied alongside, and joined in the struggle. 


\section{PART I. EMERGENCE OF AN INDONESIAN OCCUPY MOVEMENT}

There is thus a direct and unmitigated structural link between an empire, or an imperial frame of reference, and the presumed universality of a thinker thinking in the bosoms of that empire.

- Hamid Dabashi ${ }^{4}$

\section{Keeping Files on My Friends}

My first encounter with Indonesian activism was Peter Weir's 1982 film adaptation of The Year of Living Dangerously (Koch 1978). Weir's film tells the story of an Australian journalist, Guy Hamilton, on assignment to cover the last days of the Sukarno regime in mid-1960s Indonesia. As a young, queer, man growing up in the rural Western United States I was captivated by the characters and cultural references, especially the compelling cross-gendered performance of Linda Hunt as the moral and serious Chinese-Australian dwarf Billy Kwan (Figure 1), and the motif of the Indonesian Wayang Kulit..$^{5}$

On arrival in Jakarta Hamilton meets Kwan, a photographer and cameraman, who orients him to Jakarta and lobbies him to report on the people's suffering. Hamilton trusts him, even after he discovers that Kwan keeps files on all those around him, as though he were a spy (or an anthropologist) and everyone a potential informant. Early in the film, Kwan explains the Wayang Kulit to Hamilton; the Indonesian shadow puppet play. Images of the Wayang Kulit appear frequently - both in the form of the puppets, and in scenes where characters appear as shadows on opaque windows. In the film, the Wayang Kulit also serves to represent Sukarno's struggle to balance political tensions between the communist party and the military on the eve of revolution. As Kwan explains to Hamilton:

\footnotetext{
"Can non-Europeans think?” AlJazeera.com (2013)

Wayang Kulit translates as Skin Shadow or Leather Shadow, referring to the puppets made of Buffalo hide used in this specific form of the Indonesian shadow puppet theater.
} 
If you want to understand Java, you have to understand the Wayang, the sacred shadow play. The puppetmaster is a priest, that's why they call Sukarno the great puppetmaster. Balancing left with the right, their shadows are souls and the screen is heaven. You must watch their shadows, not the puppets, the right in constant struggle with the left, the forces of light and darkness in endless balance. In the West, we want answers for everything. Everything is right or wrong, good or bad. In the Wayang no such final conclusion exists. [Weir 1982]

The character of Billy Kwan is himself a kind of shadow puppet. As a Chinese-Australian man with dwarfism played by an American woman, Kwan first drew my attention to the field of questions about identity, representation, space, and place in activism. In the climax of the film, Kwan unrolls a banner out of a hotel room window and tries to broadcast a message critical of Sukarno's policies. It costs him his life.

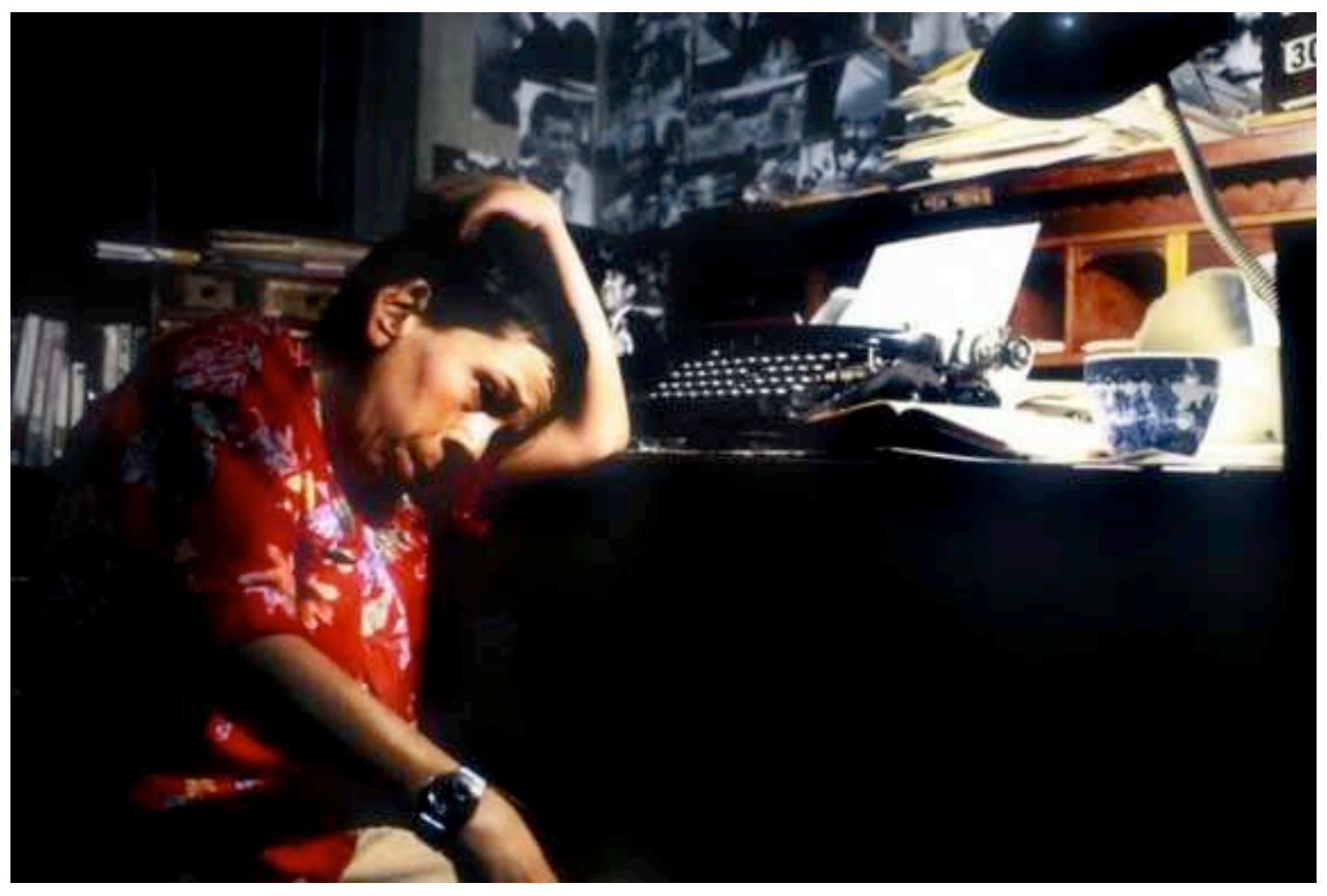

Figure 1: Linda Hunt as Billy Kwan in his office.

In October 2011 I found myself thinking of Billy Kwan and the Wayang Kulit as I began to work online with activists from the Occupy movement in Indonesia. As I joined Facebook groups, spoke to individuals through their online profiles, and kept files on my new friends, I wondered 
if I was meeting the shadows, the puppets, the puppetmasters, or something/someone other, and how I would know the difference. In the shadow plays of activism in online spaces I also wondered: how do the players see the stage?

On September 17, 2011 the occupation of Zuccotti Park, which later became the Occupy Wall Street movement, began in lower Manhattan. I spent the first week of the occupation watching from my apartment in Brooklyn across the East River. My friends were engaging with the movement and occupation, and I was involved through online activity, especially through Facebook and other social media. I was also watching live online video streams from the occupation.

Then, on September 23 (which happens also to be my birthday) the New York Times published their first coverage of the movement in an article titled "Gunning for Wall Street, With Faulty Aim" (Bellafante 2011). I was surprised that the city's local newspaper did not do much more in their report than mock activists for unconventional tactics, clothing choices and the expression of diverse views. I felt the article completely missed the point and it made me angry, it also made me an occupier. I was also certain, from my involvement with the movement online, that the article had gotten it wrong. I could see right away that the performative aspects of the occupation, which were the source of so much ridicule in the press early in the occupation, were not only vital but part of a long tradition in activism. It reminded me of the lunch-counter sit-ins during the U.S. civil rights era. I saw the whole occupation (online and offline) as performative I saw it as theater but serious political theater. I got up that day and went down to Zuccotti Park to join the occupation. 


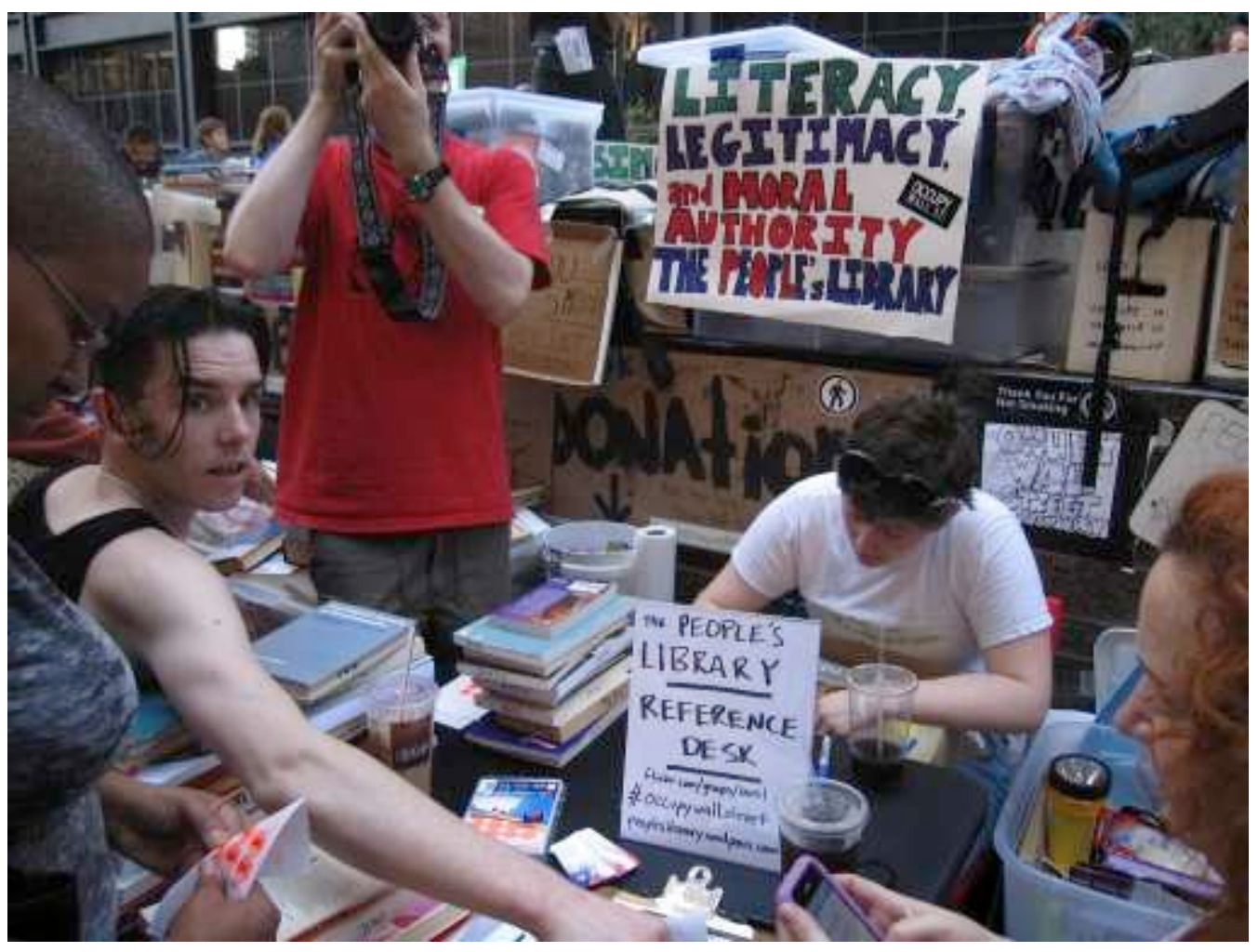

Figure 2: At The People's Library (Library of Occupy Wall Street).

When I arrived, the first place I went was the library (Figure 2), which at that point was a collection of cardboard boxes full of books that occupiers and supporters continued bringing to the park to donate. I met another activist, a lawyer who later became a core part of the OWS legal team, and asked him how I could help with the books. It was then I learned the OWS ethos: if something needs to be done, take responsibility and do it. The lesson was to look at existing structures in the park and imagine services needed by the community - see what needs to be done and then to help out by doing it. Joining the occupation required imagination. Joining the community, I learned, meant discovering or imagining what needed to be done and working with others to make it happen. With no central authority giving orders or delegating tasks, a binding sense of responsibility drew all Occupy activity and activists together. We knew that the power of the movement and the success of the encampment depended on individuals recognizing their 
role in the community and acting as if their own interests were connected to the well being of the group.

On my first day at the library I organized the small pile of books into Fiction/NonFiction, and on my second day I began creating categories: Religion, Anthropology, Sociology, Environment, Labor, Foreign Affairs, Queer Studies, Women's Studies, and others as new books arrived. It may have been the second or third day that I started to make signs for the library. As I was writing them I decided to include "The People's" in front of the word "Library." I meant this to be instructional, a reminder and lesson to new arrivals of the OWS ethos, and an announcement that the books in the library are everyone's. New visitors frequently asked: "What are these books for? How do I check them out?" and I usually answered "They're as much your books as mine, take whatever you'd like and return it if you can, or pass it on, just make sure it's in someone's hands." The library was built through small decisions and actions like these, by individuals who shared their innovations with others, and who taught the OWS ethos to new arrivals. New arrivals to the occupation, or participants in our blog, Facebook group, or e-mail list would often make suggestions starting with "someone should..." to which others would quickly reply "bottom line it!" meaning if they thought someone should do something, they should go ahead and do it; be that someone.

Despite working a full-time job while studying full-time, I continued to work at the People's Library as often as possible during the occupation. When not at the park, I continued that work online by creating and managing the library's web site, blog, and online presence across social media. I watched the occupation grow, saw infrastructure develop through enactments of our collaborative and self-directed ethos. The infrastructure of the occupation was emergent. I saw the emergence of a functioning kitchen serving thousands of meals each day; 
several iterations of organizational web sites; a medical tent, a recycling, gray water system, sanitation, a media team, a newspaper, Facebook groups; and more. And we continued to accept media donations while cataloging and organizing our growing library. ${ }^{6}$ International visitors began to show up at the occupation. One day I met a young man from New Zealand who was travelling and had re-routed to New York to join the occupation (Figure 3).

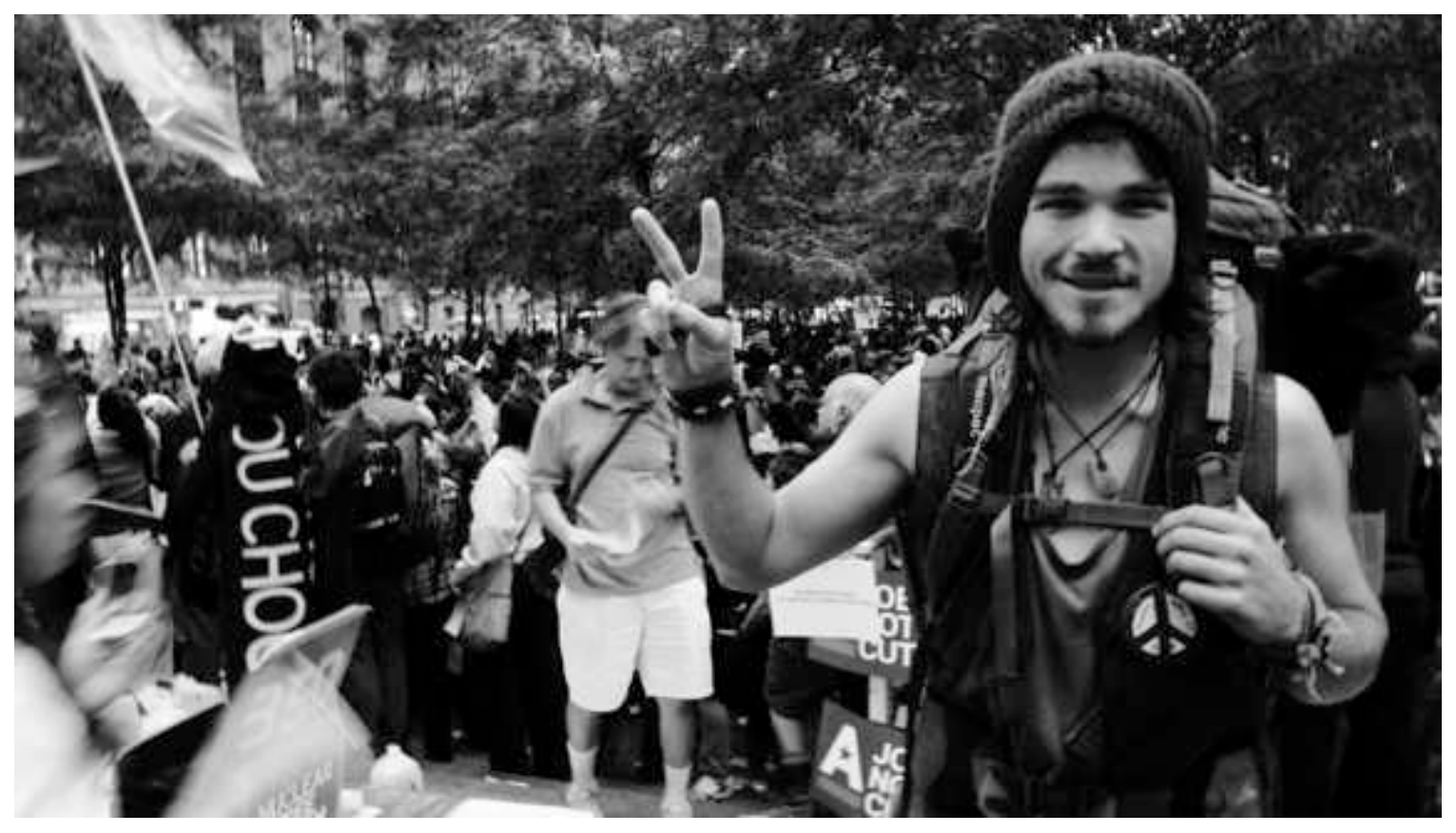

Figure 3: My Kiwi friend in Zucotti Park (taken with his camera).

In our discussions we talked about the global reach of occupy and he told me stories of how the movement was inspiring activists in New Zealand and elsewhere. I had been watching the movement spread across the United States, and libraries in Boston, Portland, and other cities were reaching out to connect with us. I hadn't yet thought about the movement spreading beyond the United States. I was fascinated by my kiwi friend's stories, and his knowledge of political and environmental issues in Southeast Asia and Oceania inspired me to begin researching the emerging international occupy movement online, and eventually led me to Indonesia.

6 By the end of the occupation almost 10 thousand books had been processed by the People's Library. This number comes from our electronic online catalog: www.librarything.com/profile/OWSLibrary 
As early as October 12, 2011 Indonesian Facebook groups appeared using the English word "Occupy" and the Indonesian word "Duduki". These emerging Occupy groups soon began engaging with existing online campaigns against corruption, against mining operations on indigenous land, and other movements in Indonesia. On October 17 the Jakarta Globe published an article by Anita Rachman with the headline "Occupy Jakarta? We Might if We Knew We Were Being Invited" (Rachman 2011). Rachman suggested that the lack of physical events organized by one Facebook group (Occupy Jakarta) demonstrated that there was no "real" Occupy movement in Jakarta. Writing about Occupy Wall Street one week later, David Harvey referred to the occupation of Tahrir Square in Egypt as proof that "it is bodies on the street and in the squares not the babble of sentiments on Twitter or Facebook that really matter" (Harvey 2011). Harvey called this an "obvious truth."

What "really matters" for Rachman and Harvey seemed to be which space the occupiers occupy. As I followed live streaming video feeds, Twitter accounts, Facebook pages and groups, and discussions in e-mail lists - I found something quite different. I saw a movement creatively confronting many of the same problems we struggle with in writing ethnography: accounting for multiple voices and positions, unstable meanings, and precarious solidarities. Based on my experiences in the movement, I wondered: what matters to participants in the Occupy movement? What constitutes an activist occupation for people whose land has been occupied? How do Indonesian activists use the Occupy discourse in light of their own histories of colonial occupation? And how do the voices of indigeneity in Indonesia engage with the movement in terms of the Indonesian occupation of indigenous land in West Papua?

To investigate these and other questions, I joined Indonesian Occupy Facebook groups mobilized around Indonesia and became friends with their creators, members and administrators. 
I integrated them into my existing life on Facebook, using my personal account. I recorded and analyzed images, texts, links and group descriptions, and engaged in conversations and interviews with group members while making it clear in my engagements that I was an occupier, an activist, and an anthropologist conducting research. I used the data I gathered to map the terrain of the online Indonesian Occupy movement in terms of the interactions between Occupy discourses (both global and local) and the narratives of activists in posts, discussions, links and images.

By making activist communities in Facebook groups my primary object of study, I investigated the global reach of the Occupy movement and the emergence of its local forms in the online engagements of Indonesian activists. I considered group members' use of Occupy discourse in terms of histories of colonial occupation in Indonesia, the ongoing Indonesian occupation of indigenous land in Papua, as well as separatist conflicts across the archipelago. I found that actions in Facebook groups were not only reflections of physical Occupy movement activity but were acts of resistance, of occupying, in themselves. ${ }^{7}$

This ethnography draws on my research to begin telling a story about the Occupy movement's global reach across cyberspace into local places, from Zuccotti Park and Wall Street in New york to Jakarta and Freeport Mine in West Papua and Indonesia - and to tell that story through my own experiences in dialogue with the Indonesian, Papuan and activist voices I encountered; what a friend of mine poetically described as a "polyphonic chorus of the subaltern."

For an extended discussion of my methods, see Appendix A.

8 This phrase comes from Alberto Duarte. For more on subaltern voices see for example: Spivak (1988) and Chaturvedi (2000). 
As I began to look at the emerging movement in Indonesia, I found that the issues of concern for Indonesian activists were more directly related to our work at Occupy Wall Street than I could have imagined.

\section{From Water Buffalo to Social Media}

In November 2010, U.S. President Barack Obama returned to his childhood home and spoke to an audience of several thousand young people at the University of Indonesia in Jakarta, West Java. He peppered his remarks with Bahasa Indonesia, the lingua franca of the archipelago, and shared memories of his life there in the 1960s. He spoke of flying kites, chasing dragonflies and the mango tree in front of their home. His colorful speech described the transformation of Indonesia in the intervening 40 years as a progression from "fields with water buffalo and goats" to "cell phones and social networks" (Obama 2010). The central theme of his visit was a "Comprehensive Partnership between the United States and Indonesia" announced alongside President Yudhoyono (Obama 2010). Obama described Indonesia's recent history of democratization as "fortified by its checks and balances: a dynamic civil society; political parties and unions; a vibrant media and engaged citizens who have ensured that -- in Indonesia -- there will be no turning back" (Obama 2010).

Field Notes - October 19, 2012 (New York):

I've just discovered the story of Alexander Aan, (born circa 1982) an Indonesian man who was reported to the Indonesian police by the Indonesian Council of Ulema for his posts on a Facebook page where he was an administrator. He wrote "God does not exist." (MacKinnon 2012)

He was a civil servant from Pulau Punjung, in West Sumatera - an active member of the "Minang" atheist Facebook group. On 18 January 2012, an angry crowd 
who heard about his posts gathered at his work and threated to beat him. Police intervened and took him to Pulau Punjung Sub-District police station for "his safety."

On 20 January he was charged for "disseminating information aimed at inciting religious hatred or hostility" under Article 28 (2) of the Electronic Information and Transaction (ITE) Law, religious blasphemy under Article 156a(a) of the Indonesian Criminal Code and calling for others to embrace atheism under Article 156a(b) of the same code.

His trial began at the Muaro District Court on 2 April 2012. On 14 June the court sentenced him to two and a half years' imprisonment and a fine of 100 million rupiah (US\$10,600) for violating the Electronic Information and Transaction (ITE) Law.

Despite Obama's public rhetoric of development, democratization, and increased freedom following reformasi, ${ }^{9}$ and the emergence of Indonesia as Facebook's second largest market (Cutler 2010), Indonesian technology users face a political-legal landscape in which certain kinds of online activity can be considered illegal or haram, ${ }^{10}$ and engagement with social media faces increasing restrictions from civil legislation (Barendregt 2006). In this environment, engaging in criticism of the Indonesian government can have dangerous consequences. U.S. foreign policy has tied the security of the Indonesian state to the "war on terror," and as a result the United States and Australia have provided increasing support for Indonesia's military. Following the 2002 Bali bombings a special forces unit of the Indonesian National Police Force, Special Detachment 88, was created (Muradi 2009). The unit was a project of then U.S. State Department coordinator for counter-terrorism Cofer Black, who later became a vice-chairman for the private military contractor Blackwater (Goodman and Nairn 2007). Detachment 88 was funded, equipped and trained by the United States and Australia and has also been used to monitor dissent in cyberspace. In 2007 Detachment 88 arrested a West Papuan human rights

\footnotetext{
9 Translation: "reforms" - refers to the period of post-Suharto reforms beginning in 1998.
}

10 Translation: "forbidden" - refers to that which is forbidden by Islamic law. 
attorney, Iwangin Sabar Olif, for forwarding an SMS message critical of the Indonesian government (Goodman and Nairn 2007). U.S. anti-terrorism surveillance personnel intercepted the text-message and the Indonesian government charged Olif with incitement and insulting the head of state (Goodman and Nairn 2007).

In 2011, as the Occupy movement in Indonesia began growing online, at least 14 people were arrested and several shot at peaceful protests against U.S. corporate mining operations on indigenous land in West Papua (Amnesty International 2011). As the Indonesian Occupy movement leveraged digital social media in their struggles for social justice, they sought to challenge globalized capitalism and its "inexorable thrust" of "linear and irreversible time" (Abram 1997:185) by rejecting the naturalization of progressive development discourses (Edelman 2005) like that in Obama's narrative of transformation from water buffalo to cell phones. These activist challenges to uneven development, opposition to Indonesian neocolonialism in West Papua, broader critiques of the Indonesian government, and critiques of resource extraction corporations were often seen by the U.S. and Indonesian governments as threats to national security and therefore conflated with terrorism. ${ }^{11}$ In light of these precarious conditions for activists working in these arenas, the Indonesian Occupy movement's actions in cyberspace and physical space shared an uncertain status as the activists challenged local, national and international authorities' oppression of political expression throughout the publicprivate continuum of cyberspace and physical spaces.

11 Steve Coll (2012) writes about an example he discovered through his Freedom of Information Act requests for U.S. State Department cables while doing research for his book: “...a highly profitable natural gas field on Indonesia's Sumatra peninsula - drew ExxonMobil's executives immediately into the bloody war for independence being waged by the Free Aceh Movement, known by the initials G.A.M. ExxonMobil paid Indonesian military forces to battle G.A.M. around the perimeter of its fields; human rights investigators accused the Indonesian forces of engaging in widespread torture and abuses. G.A.M. rocketed and attacked ExxonMobil and its employees, seeing the corporation as complicit with the Indonesian military. . . the Bush administration threatened to designate G.A.M. as a terrorist organization if it did not stop attacking ExxonMobil's property and personnel." From “U.S. foreign policy, brought to you by ExxonMobil” April 29, 2012, Salon.com 


\section{Re-framing "Occupation"}

As the Occupy Wall Street movement went global, online activists in Indonesia adopted an expanded meaning of the word Occupy through the creation of and participation in Facebook groups. This new meaning became apparent during my conversations with members of Indonesian Occupy Facebook groups in which I asked: What does it mean to 'occupy' something, to you?

Mas Arya: “To 'occupy' means to regain my dignity as an individual under the unjust political economy system (at domestic or nation-state level) and to connect myself with the same awareness which is growing at global level."

Mas Daksa: "Occupy is actually the newest callsign of revolution. it means an efforts to bring down the old system that bring no satisfaction toward the low class people and replace it with the new one"

Mbak Sinta: "occupy means just giving the pressure to 'say' the government to make change"

These responses suggest that despite a history of colonial "occupation" by the Netherlands and Japan, Indonesian cyberactivists embraced an expanded meaning of the word occupy as they joined a global movement and formed local Occupy communities of practice. ${ }^{12}$ Within these communities of practice, the word occupy was used by members to mean counter-hegemonic activism as opposed to colonial/imperial occupation or simply the persistent presence in a place for political ends, such as a sit-in action.

Membership in these communities of practice also constitutes membership in the Occupy movement both nationally and transnationally. I approach Occupy as a transnational social movement because it is: a network of actors; characterized by a "dynamic process of configuration and reconfiguration of interactions"; mobilized around issues linking the domestic

12 For the foundations of community of practice, see Lave and Wenger (1991), Eckert and McConnell-Ginet (1992), Holmes and Meyerhoff (1999). 
and international spheres; and made up of both durable as well as "contingent and temporary connections" between individual activists, existing social movements, and nonstate goups (von Bülow 2010:5). ${ }^{13}$

On October 15, a "Global Day of Action" for the Occupy movement, I was looking at an interactive map of occupations on the web site occupytogether.org and found only one listing for all of Indonesia. ${ }^{14}$ Clicking-through I discovered the listing linked to a single event on Meetup.com called "Occupy Jakarta." The event had four confirmed attendees listed as "occupiers." I wondered why, in a state where nationalist, Islamic nationalist, separatist and anticorruption movements frequently protest, there would only be one physical Occupy event with just four people attending. Clicking-through the occupiers' names led me to their personal Facebook pages and then to the "Occupy Jakarta" ${ }^{15}$ Facebook group which, at the time, had 20 "likes."

Over the next few weeks, I watched as membership in Occupy Jakarta increased to over 900 and an additional "Occupy Jakarta" Facebook group emerged. In the first few weeks of my fieldwork on Facebook, ten additional groups were created using the phrases "Occupy," "Duduki" (Occupy) or "Membebaskan" (Liberate) in combination with "Indonesia" or the name of a city or region in Indonesia (Bali, Surabaya, Jakarta, Banda Aceh). As of late November 2013, the largest group had over 3,000 members (Duduki Jakarta). ${ }^{16}$ I wondered: how and why did these groups emerge in Indonesia? How did the Occupy movement travel from Zuccotti Park to the other side of the world?

\footnotetext{
13 I am drawing from von Bülow's definition of transnational collective action here because I find it describes the Occupy movement, she does not refer to Occupy in the cited work.

14 15october.net

15 www.facebook.com/OccupyJakarta

16 www.facebook.com/groups/dudukijakarta
} 
$\mathrm{Bu}$ Citra, an Indonesian occupier who lives on the Pacific Northwest coast of the United

States told me it was her encounter with Occupy Seattle that inspired her to reach out to friends in Indonesia and start one of the Facebook groups:

I saw the occupy seattle when i went downtown to visit my daughter for lunch. we always met at westlake park for lunch because i love nature it must be outdoor. it was 14 of october. the ideas what the occupy have nothing new to Indonesian. Our founding father mr. Sukarno is against capitalism and fighting for that. (this is an interesting case to itself as we indonesian learnt that freeport and usa were behind it all to replace $\mathrm{mr}$ sukarno with $\mathrm{mr}$ suharto). So i talked to my old friend $\mathrm{mr}$ [Rachmad]. he said that people do not understand much of Occupy in Indonesia. I suggested that he sould started. In the meantime i tried to get attentions of the ideas to another group. Please be noted we have so many groups in facebook, these groups are non parties (golput : golongan putih) people that are that are tired of the present government. ${ }^{17}$ check the bellow address:

http://www.facebook.com/\#!/groups/masyarakattanpapartai/

I kept posting about occupy and finally [Tika] responded. The next day [Tika] and [Rachmad] met. [Tika] and the others in Jakarta decided that the place to start is in the front of the bursa index indonesia (wall street type) and they asked me to maintain the facebook. they started oct 18 . after a few days, i suggested that it has to be a group of facebook so people can exchanged ideas, so we started 'dudukijakarta'. ${ }^{18}$ After we started we found out that another facebook occupy jakarta has existed and occupy indonesia too, so we work hand in hand. and all decided physicly for the gatherings is only one place at b.i.i. building. ${ }^{19}$

After our first contact by e-mail, I became Facebook friends with Bu Citra and came to know her through her posts online as well as conversations in Facebook messages, wall/timeline postings, and e-mail exchanges. She loves the outdoors, and frequently posts beautiful photographs of sunsets and nature scenes on her Facebook wall. She organizes Indonesian cultural events and performances, and imports Indonesian jewelry, crafts, and fabrics on a small scale. Like many Indonesians she runs several small businesses that are usually referred to using the English

17 Translation: "(vote: class white)" Golput comes from the phrase "Golangan Putih" which means "White Group" and refers to people who choose not to vote. Under Suharto, this elective non-voting was an act of opposition against the government, however more recently it is seen as something like U.S. voter apathy. In this case, however, Bu Citra appears to mean it in the Suharto non-vote as protest sense of the word. For more see Ananta, et. al. (2005:19).

18 Translation: "occupyjakarta"

19 Bank Internasional Indonesia, owned by Maybank (Malayan Banking Berhad), the largest financial group in Malaysia. 
phrase "home industries." Many of her Facebook posts are about her daughters, who are very important to her and with whom she is very close.

$\mathrm{Bu}$ Citra describes herself as one of the first four people to create Occupy Jakarta. When I asked why she decided to become involved, she said it was "to be able to meet others in the effort to make a better Indonesia." She describes Indonesia as "pulluted with corruption, low self esteem, wrong informations, and devided due to lack of trust." After seeing the physical occupation in Seattle, she wanted to be part of the movement and bring Occupy to Indonesia. Her method of doing this was to reach out through social networks to old friends and activists, to introduce them to one another, and she accomplished this by creating and engaging with groups on Facebook. Bu Citra said it was important to create the group so that people could "exchange ideas." Ideas like those in an image created for and shared online (Figure 4), which says "All public spaces are \#Occupy spaces. We are the 99\%." It is signed with the Twitter handle and includes one of the logos of the Occupy Jakarta Facebook group.

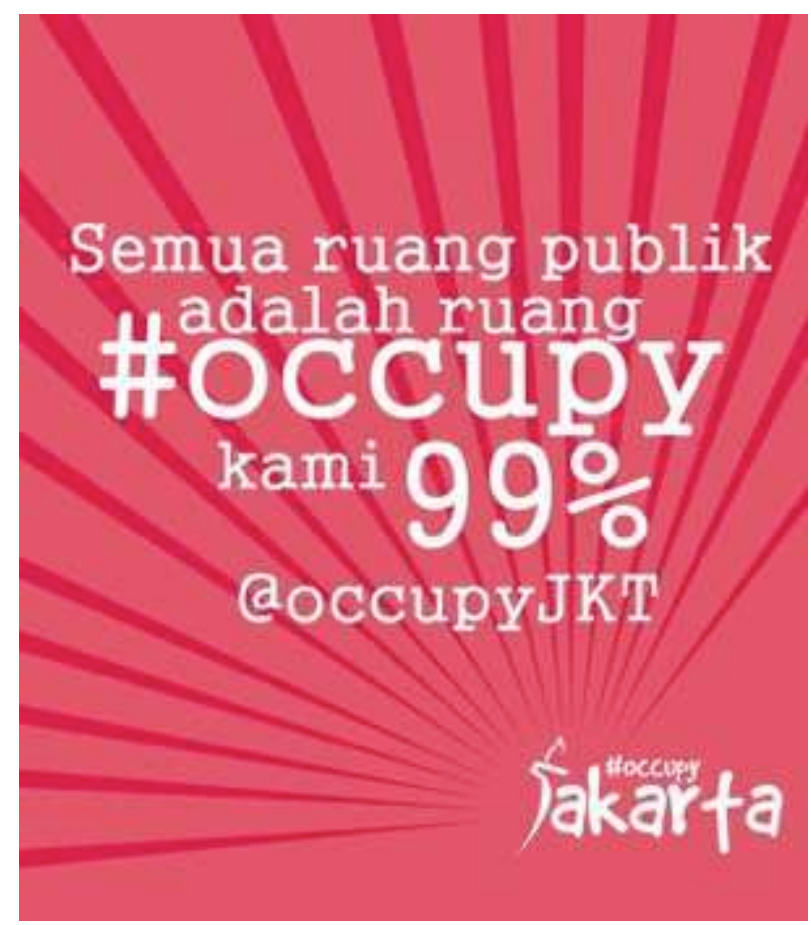

Figure 4: "All public spaces are occupy spaces, \#occupy, we are 99\%" 
Another Indonesian occupier, Mas Samir, later joined the movement online from his home in the former colonial center of Amsterdam, the Netherlands. He explained:

Yes i live in Amsterdam, iam involved in Occupy Amsterdam, but also in Occupy Jakarta, we are trying to help some other affinity groups/ circles in Indonesia to start their actions.Mostly i am doing lots of translating works, documents/ manual/ articles that $\mathrm{i}$ found in Occuppy together, etc...

Mas Samir was working on translation, taking advantage of his language skills. He was born in Java but went to university in Amsterdam and so was able to translate materials between Occupy Indonesia, Occupy Amsterdam, and Occupy Wall Street. He got involved when he saw there were no translations of Occupy documents in Bahasa Indonesia:

Yes $\mathrm{i}$ took the initiative, because 2 month ago there was no articles on OWS availlable in Bahasa Indonesia, the Indonesian Media was completely ignoring OWS. So i started contacting my friends in various leftists/ progressive circles, and we started sending each others more info about this. I am interested not only in the campaign of the $99 \%$ movement itself, but also in the refreshing horizontal type of organization, direct democracy through peoples assembly, inclusiveness, and the use of basecamp/ occupy site, as liberated area. So i began with translating OWS declaration, David Graebner interview in WP/ Guardian, etc. And it was quite usefull for friend in indonesia in understanding this movement. After $15 \mathrm{O}$, and especially after 19 October, when about 50 indonesian activist occupy BEI/ The Jakartan Stock Market, to show their solidarity with \#OWS, slowly the media attention is growing... And Now we have group is Banda Aceh North Sumatra, Makassar in Celebes, who already staged their action, and groups in Bali, Surabaya, and Bandung who are still discussing/ preparing themselves...

Mas Samir's interest is focused on the one hand in the physical occupations, but also in the textual products, and the global exchanges of ideas (including texts by anthropologist and occupier David Graeber). When I ask Mas Samir if he thinks Facebook can be useful as a place for occupiers to discuss issues, he says "Facebook, and internet are very instrumental in Indonesia to desseminate informations, and also for mobilisation. But for discussion? i don't think so..." Although Mas Samir used Facebook to interact with the Occupy movement in three locations, he perceives it as primarily a means of distributing information and mobilizing actions 
offline. This is despite the fact that I found his engagements in Facebook groups were linking Occupy movements in three countries and cities - and translating ideas between them.

Mas Samir's responses reminded me of responses from Occupiers in the United States when I asked them about online activity. His reply reflects the perception that online space is primarily a place for mobilizing and distributing information often repeated even by those who are using it for much more. Mas Samir's focus on the physical occupations also reflects his position in Amsterdam where occupiers were able to construct and maintain an encampment like that in New York's Zucotti Park. Occupiers in Jakarta were not able to maintain such an encampment.

For $\mathrm{Bu}$ Citra, these Facebook groups and online networks provide the kind of participatory meeting place, a cyberspatial plaza and clearinghouse for ideas, that Zuccotti Park provided for OWS in New York. In Facebook groups she was able to participate as a sometimesexpatriate Indonesian living part-time across the Pacific. The online movement was especially important to her because although she does not live full-time in Indonesia, she cares deeply about the future of the country. As she explains:

Sooner later revolution will be in Indonesia. It is a matter of time. These people are sick and tired of the govt bowing to the western world where Indonesian became poorer by days. Indonesian hate the neoliberal and fight it all the time that our constitutions have been changed (around 70s) to service the greed of western world. All are currupt. We want to go back to our original constitutions and Pancasila. So, occupy is just another way to express our feelings, and to know that other countries have the same problems make us learn how to explain others what is happening.

DudukiJakarta is a small group, and became a think thank, a learning place to voice our voices. But if DudukiJakarta and other non parties groups collaborates it will create chaos in Indonesia. When they will do it, I have no clue. I am not an activist full time. And I am not there. Besides, they will not tell me when they are going to move and I will not ask. Another [thing] is, some of these people are from political parties, they mingle here and there to gain friendship via the internet awaiting the moment of election or awaiting for the right moment ... 
Despite her role in bringing Occupy to Indonesia, and importance in the movement through her work online and through networking with activist allies in Indonesia, Bu Citra does not see herself as a full-time activist. However, of the Indonesian occupiers I spoke with, she consistently struck me as the most involved, the most knowledgeable, and the most passionate about the movement's early days.

My fascination with $\mathrm{Bu}$ Citra and with her story gives her voice a prominent place in this ethnography and I return to her several times. As Biehl notes "ethnographic subjects allow us to return to the places where thought is born" and "in our returns to the encounters that shaped us, and the knowledge of human conditions we produced, we can learn from our experiences anew, live them differently, acknowledging an inexhaustible richness and mystery at the core of the people we learn from" (Biehl 2013:577). On several occasions while working on this project I considered re-focusing the research toward an ethnographic portrait of Bu Citra and in some ways that is what parts of this work have become.

$\mathrm{Bu}$ Citra clearly describes her feelings about neoliberalism ("Indonesian hate the neoliberal and fight it all the time") and perception that the current Indonesian government serves the greed of the Western world. Likewise, the Occupy movement emerged in the United States at a time of record corporate profits and an ever increasing divide between what occupiers call the "99\% and the 1\%" (US Department of Commerce 2011). The movement emerged in Indonesia at somewhat similar historical moment characterized by increasing industrialization, new economic partnerships with the United States, and continuing post-Suharto liberalization blended with corruption.

An article published in the Jakarta Post on September 28, 2012 titled "Billionaires club grows fastest in Indonesia" opens by declaring "the billionaires club in Indonesia is set to 
welcome new members" and describes how in its latest "Wealth Report," banks have identified Indonesia as a frontrunner of "wealth creation" in Asia (Grazella 2012). Stefan Hofer, the Executive Director of Swiss banking group Julius Baer, said in an interview: "Indonesia exhibits the highest growth rate among [high net worth individuals] in all the countries we have looked at" (Grazella 2012). The banking groups measured "wealth creation" by looking at the number of "high net worth individuals" (HNWI), defined as those with "investable assets surpassing one million U.S. dollars, excluding their primary residences" (Grazella 2012). By 2015, the report predicts, these high net worth Indonesians could collectively hold assets of U.S. $\$ 518$ billion. This growing population of HNWI in Indonesia reflects growing inequality in a recently industrialized country that has quickly become the largest economy in Southeast Asia.

\begin{abstract}
Field Notes - February 22, 2013 (New York):
"110 million people in Indonesia who live on less than $\$ 2$ a day." -Jacqui de Lacey - Head of AusAid, Indonesia in Pulse Lab Jakarta video

"Use of mobile devices growing significantly. Today we have 180 million mobile users in Indonesia and close to 50 million Internet users. That shows that IT technology is being used by almost everybody."

-Betty Alisjahbana, Ambassador for Open Source, Indonesia
\end{abstract}

Following the economic liberalization policies of Suharto's "New Order" beginning in the mid to late 1960s, Jakarta and other urban areas began to at an extraordinary rate. Some of Suharto's earliest policies focused on reversals of the pro-communist positions of Sukarno's government through massive efforts to facilitate the inflow of capital (Haggard and Maxfield 1996). This included opening negotiations to sell resource extraction rights on indigenous lands to American and European corporations just one month after the military coup against Sukarno (Leith 2003). 
As Indonesia entered a period of industrialization and economic liberalization, new class divisions resulted in increased poverty, hunger, and dislocation of rural people. In the 20th century, the population of Jakarta increased from about 100 thousand in 1900 to more than nine million in 1995 and most of that population was added during the New Order between 1975 and 1995 (Han and Basuki 2001).

During this period of rapid development, middle and high-income families moved away from the central city to suburban, gated communities. At the same time poorer Jakartans were forced to the periphery between the suburbs and the urban core due to the expansion of development in Jakarta's center, the consequent rent increases, and lack of housing (Firman 1998, Leaf 1994, Cybriwsky and Ford 2001). As migration to Jakarta continued to grow and as poor Jakartans were pushed to the periphery, new dense residential areas called kampung (villages) emerged in the periphery of Jakarta (Cybriwsky and Ford 2001). The kampung are associated with informality, poverty, and the maintenance of rural traditions in an urban setting. Their emergence in Jakarta was a sign of increasing spatial segregation and increasing socioeconomic disparity in Indonesian urban life (Firman 2004).

Like many Indonesian Occupiers, Bu Citra sees a solution to these problems of uneven and unjust development in a return to the anti-imperialist, anti-capitalist Sukarno-era. She sees the Occupy movement as one means to imagine a future based on that model. Bu Citra closed one of our e-mail conversations about these issues by sending me three links and a video: President Sukarno's speech at the opening of the Bandung Conference (April 18, 1955); ${ }^{20}$ President Sukarno's speech at Yogyakarta (Jogjakarta) on the West Papuan issue (December 19, 1961); ${ }^{21}$ a blog post titled "Pancasila, Sukarno's vision for Indonesia",;2 and an interview with

${ }^{20}$ www.fordham.edu/halsall/mod/1955sukarno-bandong.html

21 www.papuaweb.org/goi/pidato/1961-12-jogjakarta.html 
Suharto's son-in-law and current presidential candidate Prabowo Subianto who has been accused of committing war crimes in East Timor during his tenure in command of Kopassus, the Indonesian military special forces unit. ${ }^{23}$

Her political perspective is, of course, not representative of every Indonesian occupier. Bu Citra's focus on the return of a Sukarno-like era is not universal although the core anticapitalist message is a central part of the Indonesian Occupy discourse. However, I found no unifying political affiliation among Indonesian occupiers. In an open-ended questionnaire posted to Indonesian Occupy Facebook groups, answers to my question "How would you describe your political views or beliefs?" resulted in a range of responses such as: "moderate-transpartisan," "liberal socialist," "humanity," "democrat-social," "anarchist," and more. Across these political identifications, however, I found group members consistently using the Occupy discourse around issues of global U.S. imperialism, capitalism in Indonesia, and government corruption, while drawing clear connections between OWS, Wall Street, the Occupy movement and local activist concerns and movements in Indonesia.

\section{Communities of Practice and Wayang}

I was introduced to the idea of a "community of practice" in a linguistics seminar with Maryam Bakht at Hunter College, CUNY. The concept struck me as an interesting and useful way to consider membership in the often difficult to define Occupy movement. Bakht (2010:26) writes that a community of practice is defined by "both its membership and by the social and linguistic practices in which the community engages" and "is based on the idea that, in mutual engagement in an endeavor, groups of people constitute a social organization" (Lave and Wenger 1991,

22 inidisini.wordpress.com/2011/05/27/pancasila-sukarnos-vision-for-indonesia/

23 www.youtube.com/watch?v=08SMkHVMK3E 
Eckert and McConnell-Ginet 1992, Wenger 1998). Drawing attention to parallels with Bourdieu's habitus, Bakht notes that the "local meaning within the community is constructed within the community of practice based on the interests, beliefs, and ideologies of its members" (Bakht 2010:26).

One characteristic of the Occupy community of practice is the use of Occupy to refer to activism for social justice. Further characteristics of the Indonesian occupiers also satisfy Wenger's list of features that must exist to consider a group a community of practice: mutual engagement; a joint enterprise; and a shared repertoire (Wenger 1998:73). While members of the Occupy community of practice may also be members of the Golput groups (as Bu Citra describes), members of indigenous activist groups, anarchists, communists, or others - it is the affinity of social justice goals across these memberships and their use of the term Occupy (to characterize counter-hegemonic activism rather than colonial or imperial domination) that situate their membership in the Occupy community of practice.

The community of practice is a useful model for looking at the Occupy movement because as Bakht notes it allows actors to change alliances and engage in adversarial positions in relation to other members of the community of practice without discarding membership (2010:26-28). In one salient example of this in practice, as indigenous activists critique the Occupy movement's "occupation" discourse and call for use of the alternative phrase "decolonize" they critique the movement from adversarial positions within the Occupy community of practice while maintaining membership.

The chorus of diverse views is perceived within the Occupy movement as a strength and yet often characterized by the media and critics as a weakness. As I think about the debates between members within the movement, and the role each of them plays in the production of 
knowledge and in telling the story of Occupy, I am reminded of my visit to a Wayang Kulit puppetmasters house in East Java.

The Dalang (puppetmaster) invited me into his home and upstairs to his workshop where he made the puppets. His house was in the kampung, the densely packed neighborhoods of alleyways and homes often dismissed by the wealthy Indonesians as the "poor parts of town." In his second-story workshop puppets in process were hanging upside down from the walls and were stacked on tables. There were characters from the Javanese tradition: Arjuna, the prince; Kunti, his mother; Cangik, the female clown; and also inventive contemporary characters created by the Dalang: a family of three ghosts, all wrapped in burial shrouds; and monsters with long centipede like necks. Several trunks held piles of completed puppets. The unpainted puppets were translucent and by holding them up to the afternoon sun coming into the window I could see the veins running through the Buffalo hide (Figure 5).

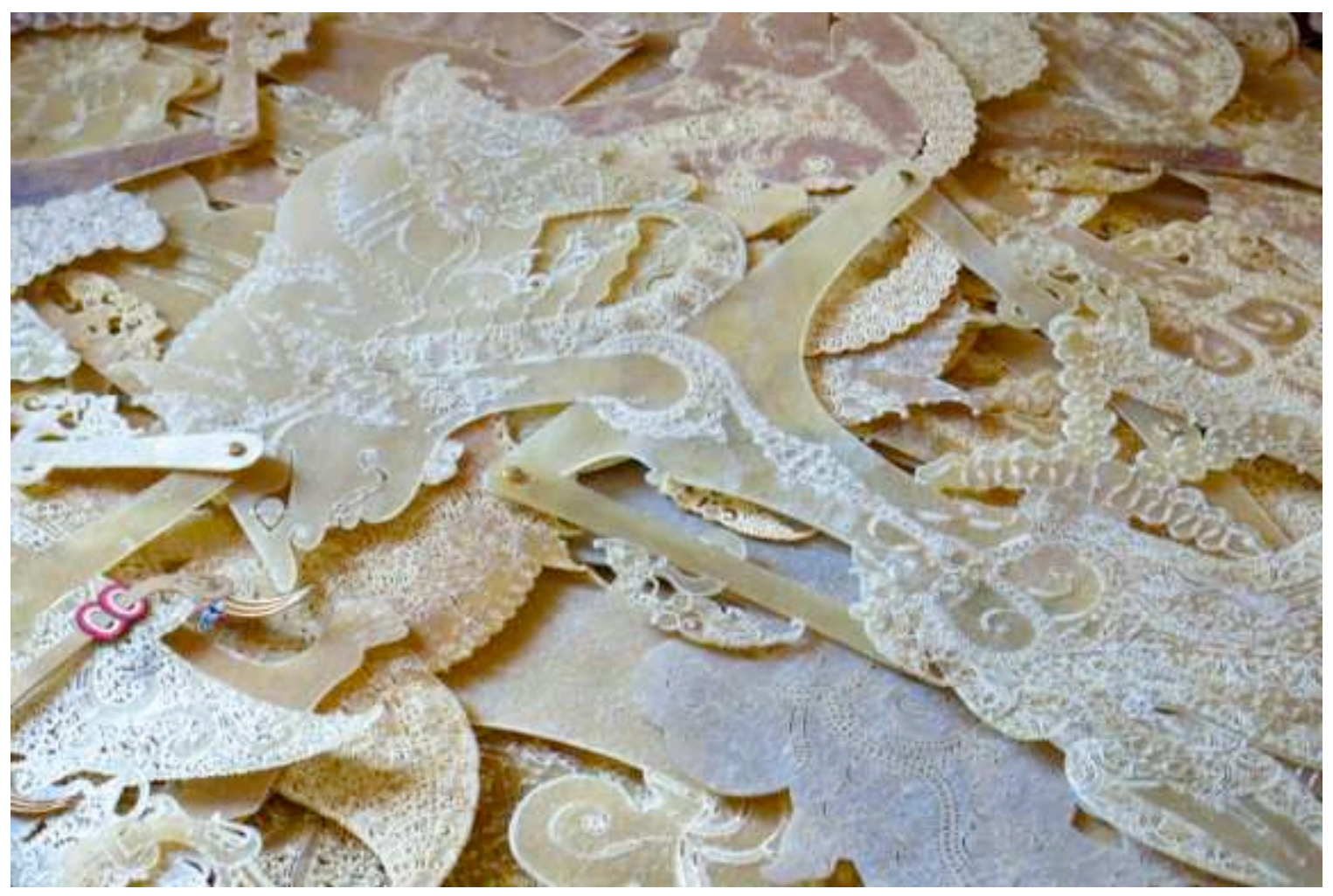

Figure 5: Unpainted Wayang Kulit Puppets at the Dalang's house. 
The slightly transparent stick of Buffalo horn running up the center like a spine holds the puppets upright and provides a handle for the puppetmaster. The meaning of Wayang (puppet) Kulit (skin) and its reflection of their sacred and ghost-like nature became apparent when I finally saw that these skin puppets were exactly that as they are made entirely from parts of an animal's body.

When the Dalang is on stage at a performance, he is dwarfed by the dozens (Figure 6) to hundreds (Figure 7) of puppets lined up on either side of him; the diversity of shapes, characters, and sizes is astonishing. Earlier, when I saw the same Dalang performing on the top of Mount Kawi, it seemed impossible that there could be so many characters included in one performance but the performance goes all night, and each of them have a voice in the stories he tells.

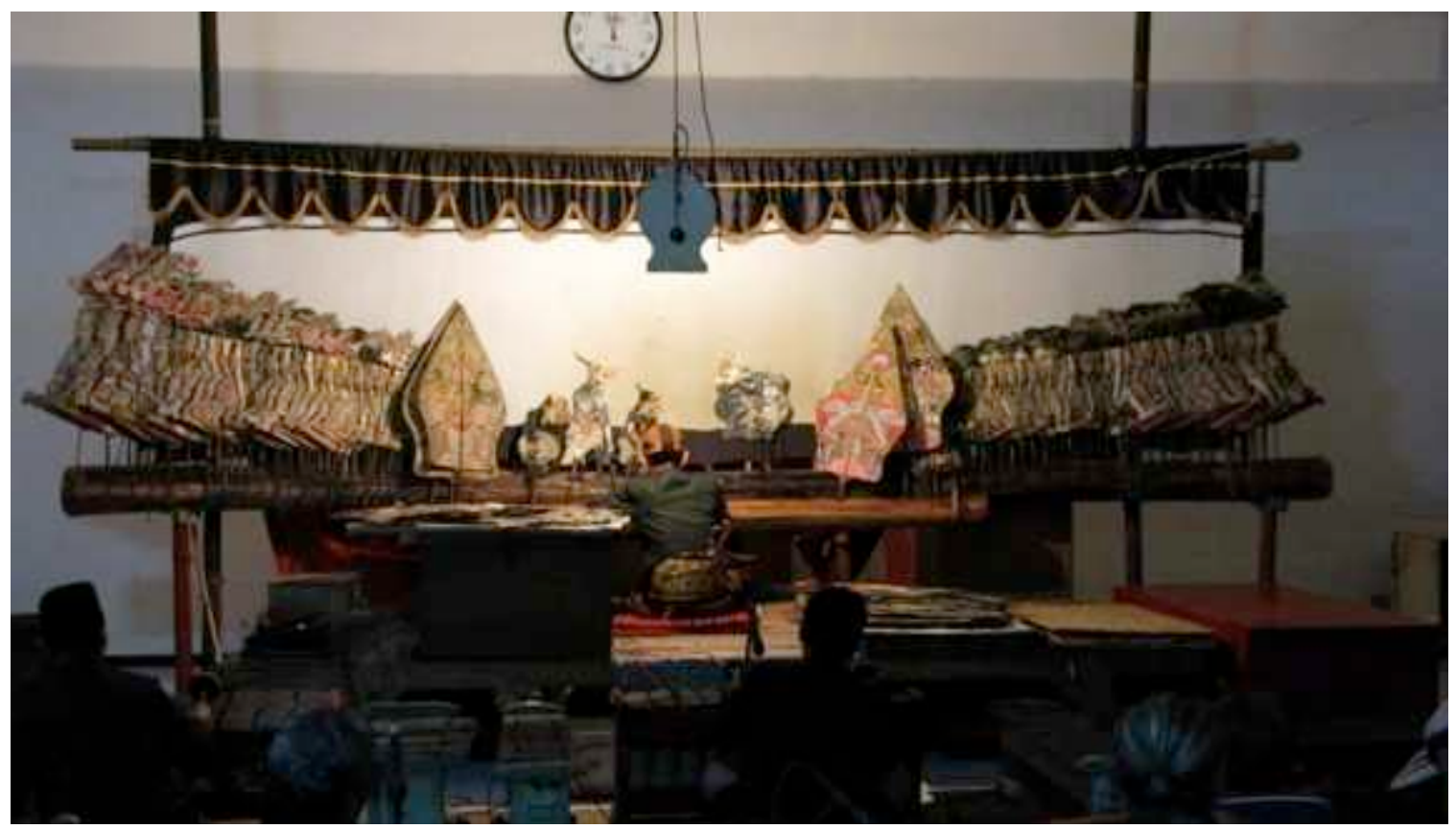

Figure 6: A small Wayang Kulit performance on Mount Kawi, East Java.

The Occupy community of practice reflects this narrative constructed through many voices, many characters - some positioned in opposition to others, some the same character in different 
guises. Despite the apparent dissimilarity of the groups, causes and individuals who coalesced around Occupy, all of the activists participated in the shared discourse around mutual engagement.

Non-Indonesians attending a Wayang performance often wonder why it seems so chaotic. The crowd is not paying attention. The Dalang is smoking, occasionally reaching up and moving a puppet's arm and speaking a single line into the microphone. Many audience members are asleep on couches. Others are surfing the Internet on their mobile phones. What's going on here?

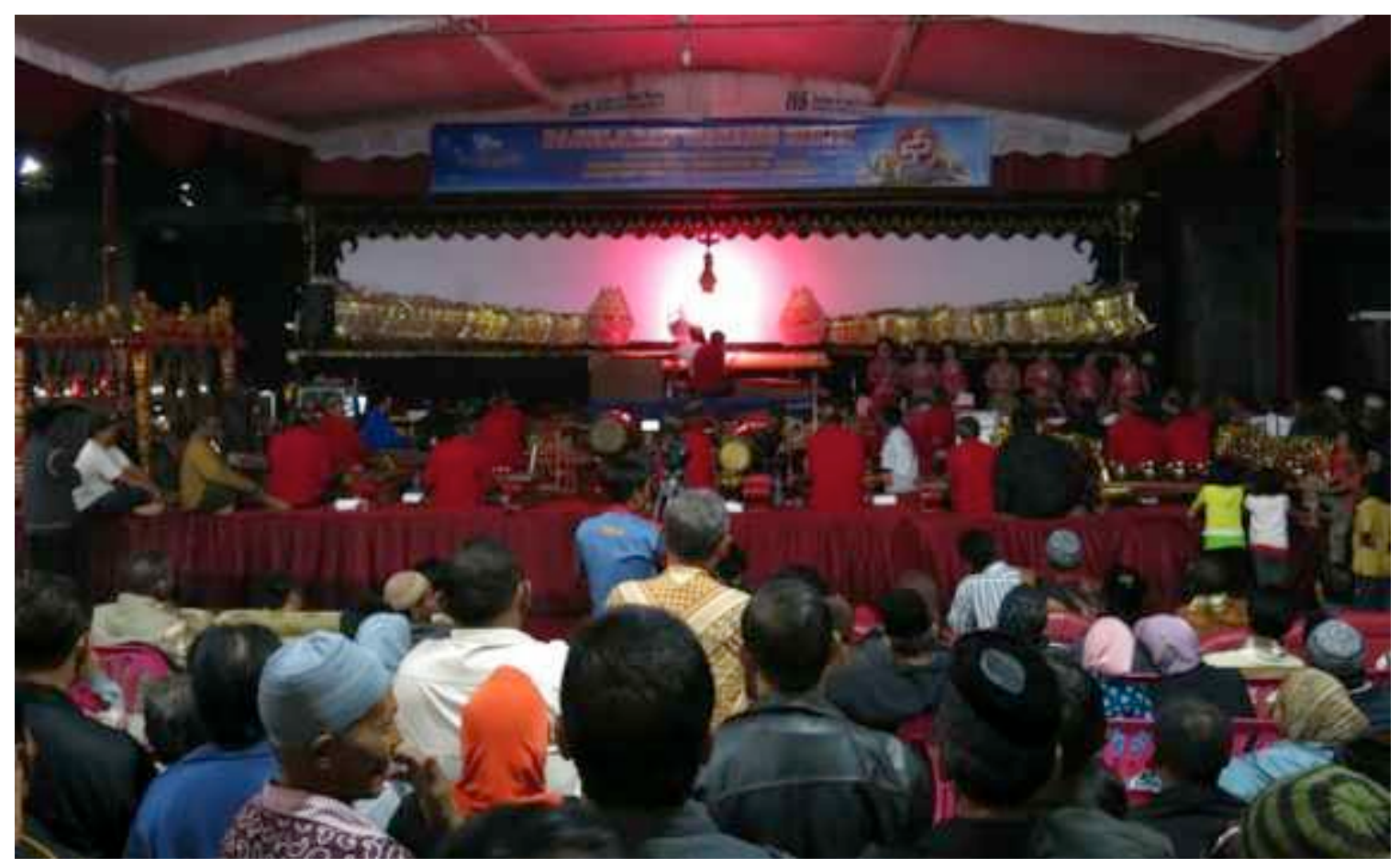

Figure 7: A large Wayang Kulit performance on Mount Kawi, East Java.

The Wayang is theater, but it is also the collective manifestation of a temporary social space. Wherever the performance occurs, there is an occupation of sorts. Despite the theatrical architecture of the space, the puppets and their story are not necessarily the focus. Instead, attendees are interested in the side conversations, the reunions, the stories of new and old friends. These back channels of the social space are the other half of the performance, the Wayang serves 
only as a reason to bring the people together into the moment, into the long moment - often until dawn.

\section{Protest Signs and Shadow Puppets}

The profile image for the first Indonesian Occupy Facebook group I joined was a digitally produced drawing of a protester holding a sign (Figure 8) made by Nobodycorp. The starkly colored graphic image depicts the two red hands of a silhouetted figure holding a sign, obscuring the figure's face.

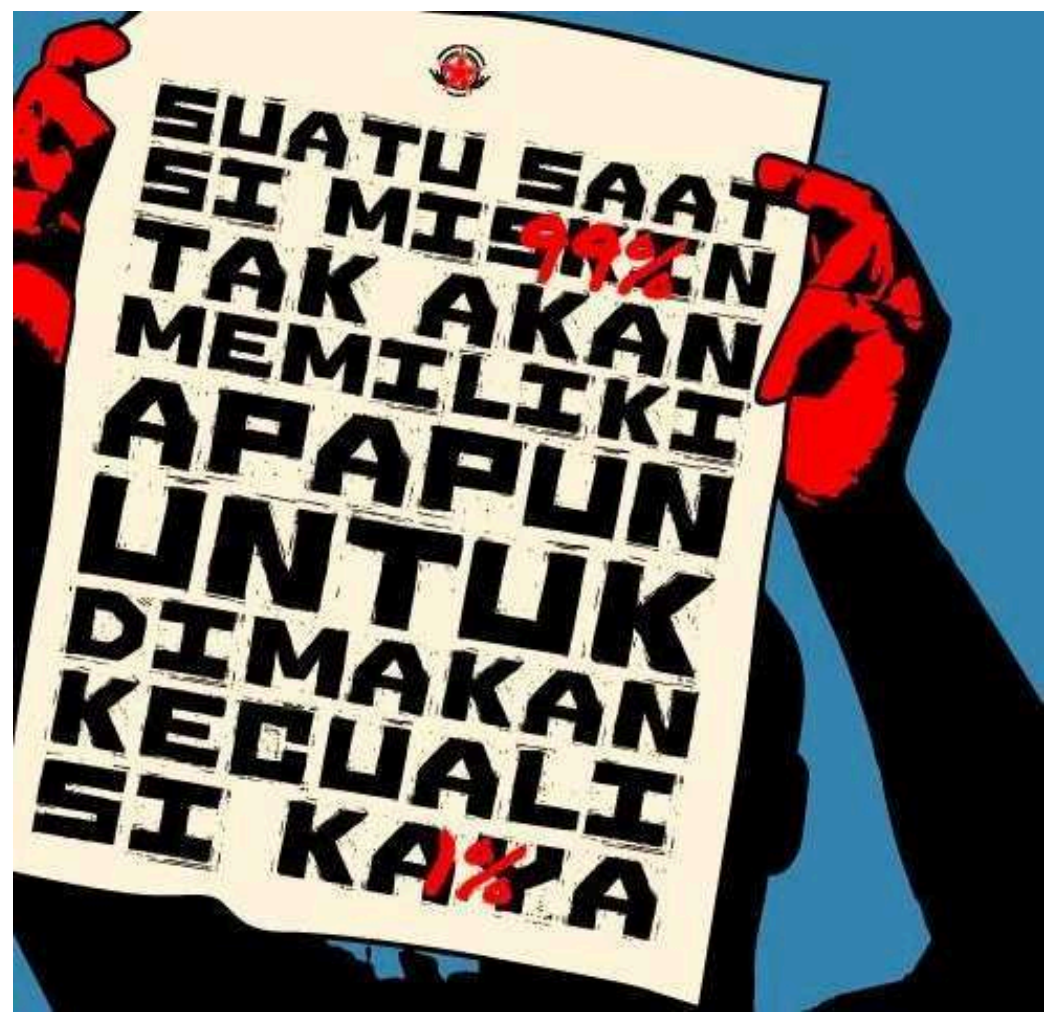

Figure 8: Occupy Jakarta group profile image.

The roughly hewn text is scaled to fill the sign's rectangular shape with the proportional regularity of a block print:

$\begin{array}{ll}\text { SUATU SAAT } & \text { [a moment] } \\ \text { SI MISKIN } & \text { [the poor] } \\ \text { TAK AKAN } & \text { [will not] } \\ \text { MEMILIKI } & \text { [have] }\end{array}$




$\begin{array}{ll}\text { APAPUN } & \text { [any] } \\ \text { UNTUK } & \text { [for] } \\ \text { DIMAKAN } & \text { [eat] } \\ \text { KECUALI } & \text { [except] } \\ \text { SI KAYA } & \text { [the rich] }\end{array}$

The meaning could be translated into English as: "At one point the poor will have nothing to eat but the rich." The word "miskin" (poor) has been overwritten with "99\%" and the word "kaya" (rich) with "1\%" - situating the phrase within the Occupy discourse so that it reads: "At one point the $99 \%$ will have nothing to eat except the $1 \%$." Soon after I first saw this image, a photograph was posted to the same group's wall of a young man, a protester standing outdoors, holding a printed version of that image (Figure 9). This photograph of a protester holding a sign, itself an image of a protester holding a sign, created a self-reflexive embedding of an image within an image - a mise en abîme. This mirroring is a reflection and also more. It is not only a doubling, it is also inter-textual, and it is reflexive.

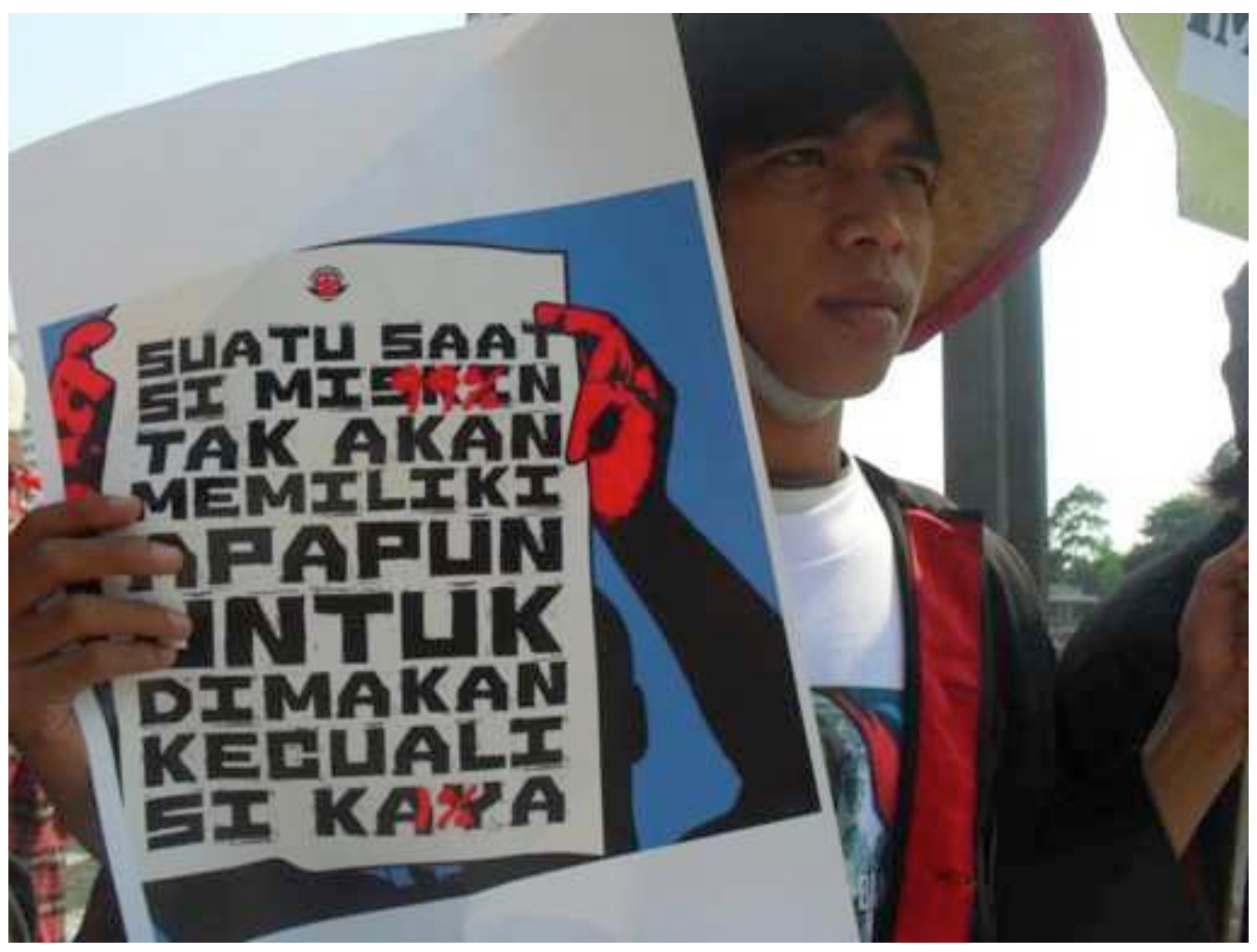

Figure 9: Image posted to Occupy Jakarta group wall. 
The photograph of a protester holding a sign (of a protester holding a sign) was posted on Facebook, and became another, different, sign. The more I considered the context of this posting, the deeper the embeddedness became. Looking at this reflection turned in on itself and then posted online, I thought: Is one modeled after another? I was reminded again of the Wayang Kulit. Which is the shadow and which is the puppet?

The Indonesian shadow puppet theater, Wayang Kulit, historically served as a forum for producing critiques of local politics, as the puppets took on voices of their own and drew attention to corruption or the personal exploits of village heads (Pemberton 1987:22). However, after 1965 when many Dalang (puppeteer or puppet masters) were identified as associated with the then outlawed Partai Komunis Indonesia (PKI), ${ }^{24}$ the performances took on a distanced and ceremonial order reflective of the broader chilling effect across Indonesian performing arts during Suharto's New Order regime (Pemberton 1987:21-22). The production of similarly critical narratives through the posting of text and images on the walls of Facebook groups resurrects and reflects this traditional activist aspect of the puppeteer through a new form of shadow play on social media. Facebook group and page administrators are able to post to Facebook group walls from the speaking position of the group's identity, speaking through the group's page without revealing their own identity. In this way, the group appears to take on a voice of its own and as such can "speak" a dynamic collaborative and polyvocal discourse composed of an unlimited number of group administrators through what appears to the audience as a single voice.

When I saw the Nobodycorp image of the red hands holding the protest sign about the rich and the poor, the $1 \%$ and the $99 \%$, I first read the post as a broadcast from the administrators

\footnotetext{
24 Translation "Indonesian Communist Party"
} 
of the Facebook group referencing protest activity in the physical world. I often hear this interpretation of online activity, that Occupy movement activity online is a reference back to action in the physical world, or at most a staging ground to coordinate physical action. ${ }^{25}$ Online action is then seen as a reflection, necessarily less-than. When presented with data like this image, digital anthropology might suggest tagging or coding it with the obvious characteristics (protest, slogan, young man, Occupy discourse, inequality, etc.) and moving on.

But unlike other images posted to Facebook documenting protest actions in the physical world - this photo was not posted with a description of where it was taken, when it was taken, or what action it was associated with. This photograph of an activist holding a sign, itself an image of an activist holding a sign, which is in turn the profile image for the Facebook group is first, a self-reflexive embedding of an image within an image - but it is also more.

Through my participation in the Facebook groups, I began to notice that users were not modifying their own profiles, profile images, or filling their walls with Occupy related posts in order to become occupiers (as I saw U.S. occupiers doing). Instead, Indonesian cyberactivists were going into the groups or pages and being occupiers there, in those spaces. They were enacting Occupy in the groups through posts, conversations and other engagements.

As I considered what I was noticing about relations between users, their profiles and their activity in groups, and how users were distinguishing their profiles from their actions in groups I realized this image was not posted to reflect and mark a moment in physical space but instead to produce one in cyberspace. This reversal of assumptions about what cyberactivist's online activity entails led me to see these Indonesian Facebook groups more as their users were seeing them, not only as echoes of activity in the physical world, but as occupations in themselves.

${ }^{25}$ As in Caren and Gaby (2011) 
Through these groups and pages, the Indonesian activists were also occupying Facebook, occupying cyberspace.

Offline actions directed at online spaces have become a common (yet understudied) activity for regular Internet users. Users frequently pose for photographs or stage scenes and photograph them intending to produce an image and a story specifically for Facebook, Twitter, Instagram or another online social media venue where users share photographs. These are offline actions for online places - such as this image posted by the Indonesian occupiers, the ubiquitous selfies (photographs of the self taken by extending the arm) and other physical-world-based online-directed acts. Building on Mauss, I consider these to be online "techniques of the body" or cyber-techniques of the body.

Field Notes - July 18, 2013 (Kepanjen, East Java):

In a village full of small homes, surrounded by rice fields, cassava and corn fields and tree plantations - an hour outside of Malang by train - a village full of homes seemingly in disrepair, but with beautiful collections of houseplants and birds in cages - I found at Adi's house a desktop computer, a wireless modem, and a laptop. Adi brought his own laptop and so there were three computers in the home all online. His aunt, who runs the household cooked us a meal of traditional foods to break the fast, fried tempe (goring tempe), fried tofu (goring tabu) and vegetables, peanut sauce (samba pecel), and white rice. She has a water reservoir on the roof that is fed from a well which sometimes overflows and floods down the walls of her kitchen. And yet, she also has a cell phone and a laptop and a desktop. She showed me all of her friends on Skype who she talks to regularly - all over the world, India, Japan, Europe... And while we were sitting and talking after dinner, as the mosque in the village began to beat the drum calling everyone to the special 6th prayer for Ramadhan (tarawih), she and I became Facebook friends - she added me from her laptop and I accepted the request from my Indonesian mobile phone (HP: handphone) sitting next to her. Boys from the village were playing in the room with her sons, Adi's cousins-one of them in the traditional shirt and hat of a muslim man - holding RL Stine's goosebumps book. There is an often repeated perception of a significant digital divide in Indonesia, and in places that are developing like Indonesia. But what I found is that everywhere, no matter how small the village, how remote the homes - from a family of banana pickers living in a Village, to the tea plantation workers at 
Wonosari tea factory, to Adi's relatives in Kepanjen - Indonesians all have mobile phones (HP: handphones) and they all have access to the internet. They use them to read news, to use GPS maps, to go on twitter and Facebook, but especially to SMS.

On October 19th, 2011 blogger Nugroho Budianggoro (2011) described the first Indonesian Occupy protest in physical space on demotix.com. Budianggoro described the event as a peaceful protest in front of the Jakarta Stock Exchange lasting three hours and attended not only by about a dozen protesters, but also by "numerous police and security guards, including a water canon." Budianggoro also noted in his report that "Occupy Jakarta started in Twitter and Facebook conversations." The event was filmed by participants and video was made available on YouTube. The video and photographs of the protest reveal signs, images, and references that echo the visual and textual language deployed in the Facebook groups.

Like action in physical space and occupations of public-private squares, occupation of online space involves frictions with boundaries, legal lacunae, questions of privatization, and surveillance - the whole complex of challenges faced by occupiers of physical space. Facebook is not only a tool for social networking and activism, it is also a U.S.-based, corporate, for-profit, data-mining enterprise and its potential for use in resisting institutional power must be considered in that context. Users engaging in political action on the cyberspatial plazas are negotiating both global and local barriers to participation as well as transnational aspects of the globalized Internet.

In the first two months of the Indonesian Occupy movement, four occupiers were killed while physically engaging in protest at Occupy related events. On December 7, 2011 another death was added to the list in Indonesia's first case of self-immolation. Mas Sondang 
Hutagalung, a law student and activist went to Merdeka Palace in Jakarta, the official residence of the President of Indonesia, covered himself in gasoline and set fire his body. ${ }^{26}$

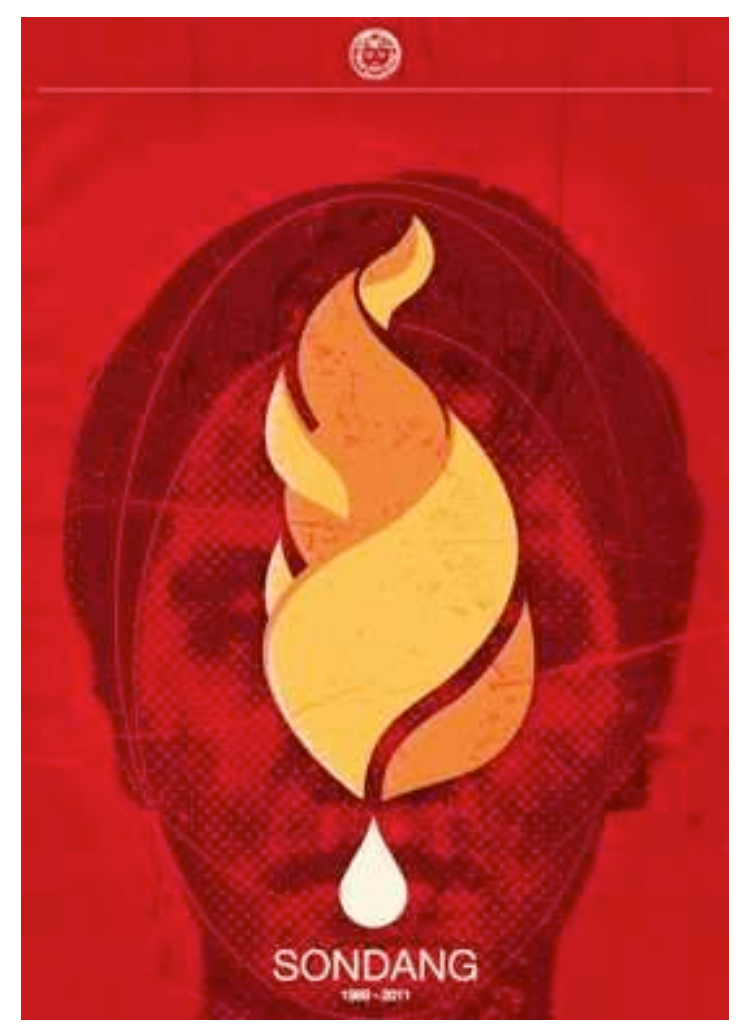

Figure 10: Memorial image for Mas Sondang.

Mas Sondang died in the Cipto Mangkunkusumo intensive care unit several days later from burns that covered over 90 percent of his body. Memorial images appeared on Occupy Facebook groups marking his death (Figure 10) and I watched as the users came together in the groups to mourn the loss. He had been active and well known in anti-corruption and human rights activist circles, and witnesses report that he shouted anti-government messages as he set fire to himself. Mas Sondang's life was celebrated and his death mourned by the Occupy Facebook group members in Indonesia. Members of the group "Duduki Jakarta"27 made several hundred posts to their group wall expressing solidarity with Mas Sondang. In one of the first on December 9, 2011

\footnotetext{
26 The immolation was reported widely in Indonesian and Southeast Asian press, for example see: www.thejakartapost.com/news/2011/12/12/death-self-immolating-student-sparks-online-movement.html

27 Translation: "Occupy Jakarta"
} 
Tika, a group administrator involved since the beginning of the group, posted a photo of Mas Sondang and described the immolation as "aksi heroik" a "heroic act." New solidarity groups also emerged across social media and activists compared Mas Sondang to Mohamed Bouazizi, the Tunisian street vendor whose death by self-immolation sparked the Tunisian revolution, as they posted: "Time for change, remember Tunisia." 28

Mas Sondang's immolation took place in physical space and it is difficult to imagine a more physical and material act than his decision to ignite and burn his own body as protest. His immolation, his physical act as activism - also then took place repeatedly in cyberspace as the narratives about his action framed him as a hero and remembered him as an icon. His immolation became representative of the movement when it was iconized through transformation into a series of posters by one of the most prolific image producers for the Indonesian Occupy movement, Nobodycorp Internationale Unlimited (hereafter Nobodycorp).

During the occupation in New York another of Nobodycorp's images for Occupy Jakarta (produced for online use and distributed through the Occupy Jakarta Facebook groups) was printed full-page in the Occupy Wall Street Journal Issue \#4 (Figure 11). The issue was devoted to posters from the movement but contained only one image from an occupation outside the United States, this poster for Occupy Jakarta.

28 www.thejakartapost.com/news/2011/12/12/death-self-immolating-student-sparks-online-movement.html 


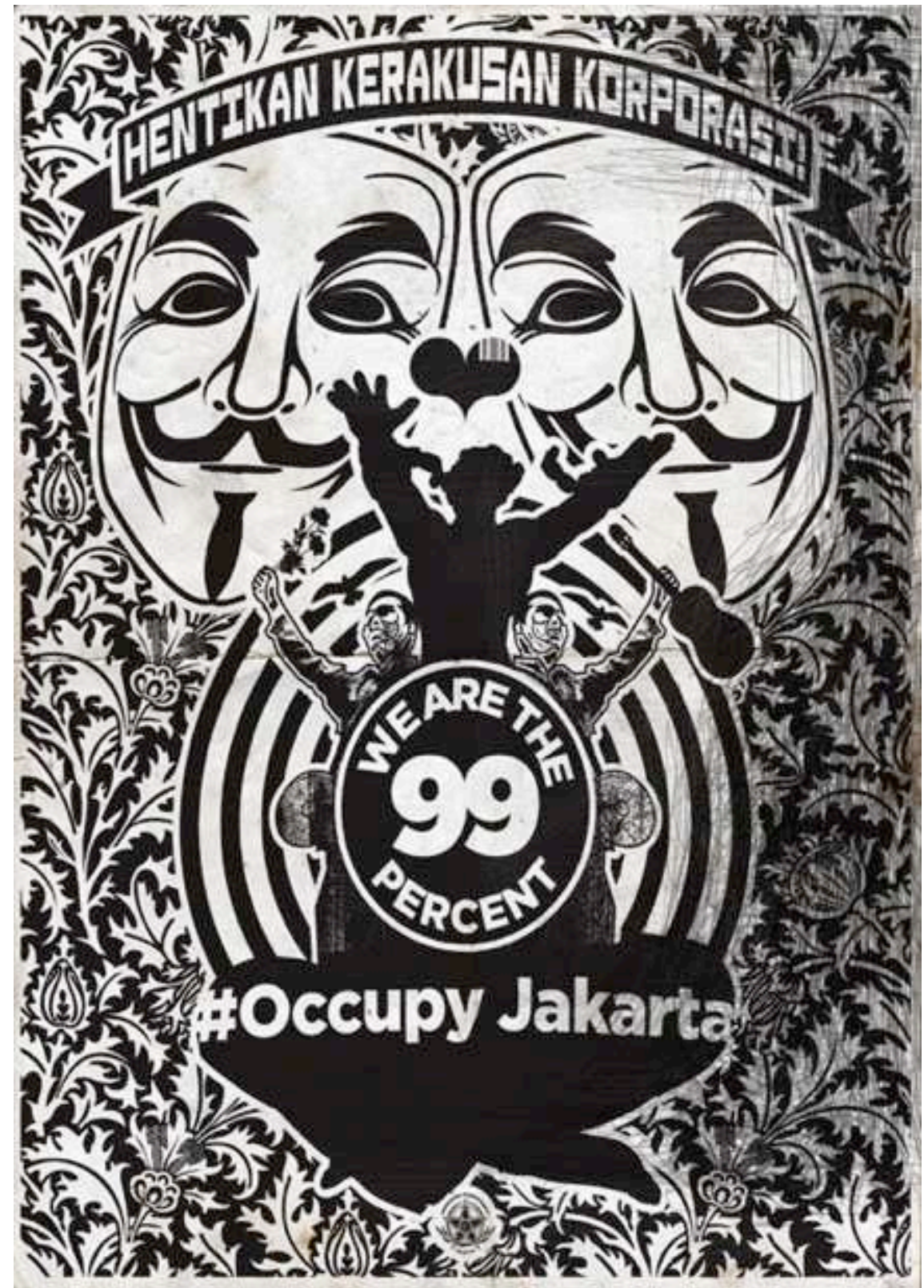

Figure 11: Nobodycorp. Occupy Jakarta poster. 


\section{PART II. REFORMASI, OCCUPY AND THE RUINS OF EMPIRE}

Let us consider first of all, the radical and necessary heterogeneity of an inheritance [...] An inheritance is never gathered together, it is never one with itself. Its presumed unity, if there is one, can consist only in the injunction to reaffirm by choosing. "One must" means one must filter, sift, criticize, one must sort out several different possibles that inhabit the same injunction. And inhabit it in a contradictory fashion around a secret. If the readability of a legacy were given, natural, transparent, univocal, if it did not call for and at the same time defy interpretation, we would never have anything to inherit from it. We would be affected by it as by a cause -- natural or genetic. One always inherits from a secret -- which says "read me, will you ever be able to do so?

-Jacques Derrida ${ }^{29}$

\section{Toward a Genealogy of the Indonesian Occupy Movement}

When I first began doing research on and writing about the Indonesian Occupy movement I was taking a graduate seminar in Law and Anthropology with Yukiko Koga at Hunter College, CUNY. The seminar focused on anthropological approaches to law, justice, and testimonial practices. Drawing from Koga's work, the cases explored in the course all dealt with the "role of law in redressing the past injustice and violence arising from the Second World War." ${ }^{30}$

Koga's discussions of her research along with the readings in the course were instrumental in shaping the way I thought about the Indonesian Occupy activists as I began to do my own research and as I wrote about that research. I found myself drawing parallels between the Chinese and Japanese relationships Koga looks at and the ways Indonesians continue to come to terms with colonial, imperial, and New Order inheritances, as well as how those colonial relations influenced the New Order, and how survivors and activists are working through those inheritances today. I began to see the New Order as a colonial echo in Indonesia so that I

29 Specters of Marx, the state of the debt, the Work of Mourning, \& the New International (2006:18)

30 Quoted from the course syllabus. 
understood Indonesian activists as always engaged in pursuit of an accounting for policies and actions that persisted from the New Order and which could also be traced back to colonial era power relations. In this way, Koga's research, the works she selected for our seminar, and her suggestion that I look at Ann Stoler's writing lead me to think about my project in terms of some key ideas that I would not have encountered otherwise: memory, inheritance, testimonial practice, accounting, debt, international justice, imperial relations, ruins of empire, and the unmaking of empire.

From 2011 to 2012 I looked at online activity of Indonesian Occupy movement members to investigate how early Indonesian Occupy Facebook groups were created and how they engaged with existing local social movements in Indonesia. I found that the proliferation of online Occupy groups afforded opportunities for Indonesian Facebook users participating in local online activism to join the globalizing Occupy movement within a familiar framework (Oman-Reagan 2012). As I began my work with Indonesian Occupy activists, I started with the question: What constitutes an occupation for online participants in the Indonesian Occupy movement?

Through my online fieldwork, I traced the origins of the first Indonesian Occupy Facebook group (Occupy Jakarta) back to one of several of my informants, including Bu Citra an activist who learned about Occupy during a visit to Occupy Seattle. In 2013 I began new conversations with $\mathrm{Bu}$ Citra in hopes of learning about possible historical connections between the emergence of Occupy in Indonesia and the history of social movements in the country. ${ }^{31}$ In

31 These new conversations were inspired by calls to overcome a presentist tendency in social movement studies by, in part, examining activist biographies (Edelman 2001). 
these new discussions, I about her pre-Occupy history of activism and learned that she was witness to both the 1965 coup in Indonesia as well as the 1998 student uprisings in Jakarta. ${ }^{32}$

Bu Citra told me she identifies as a "working-class Indonesian" and connects this identity to her responsibility to "be in the front row" of activism in Indonesia today. Her recollection of the 1998 movement and her response to questions about 1965 inspired me to focus on my conversations with her as an attempt to probe biographical and historical questions about continuity across Indonesian social movements. I also sought to merge that analysis with theory and previous scholarship on colonial inheritance and memory.

This expansion of my research into Bu Citra's past was initially guided by several questions:

What can activist biographies and the lived experiences of movement participants (Edelman 2001) reveal about how the Occupy movement arose in Indonesia?

What does the broader political, social, and historical field in which the Occupy movement has emerged (Edelman 2001) suggest about how and why Occupy discourse was adopted and used in Indonesia?

How do colonial history and its "imperial formations" influence Indonesian social movements and what are the Indonesian activist responses to these "ruins of empire" (Stoler 2008)?

Through explorations of activist memory and the imperial and colonial histories of Indonesia, I hoped to understand how the New Order emerged within what Stoler calls the "ruins of empire" and how these ruins influenced activist engagements in the early Indonesian Occupy movement.

I am interested here in the interactions of activists, the state, history, and memory at several scales: national movements within Indonesia (anti-corruption, West Papuan independence), existing transnational movements (struggles against resource extraction corporations), and the emergent online Occupy movement (Occupy Jakarta, et al.).

32 The 1998 student movement led to the resignation of Suharto and the downfall of his "New Order" regime and marks beginning of the period of Reformasi (reforms). 
In his 2001 review of anthropological contributions to the field of social movement studies, Marc Edelman points to a gap in the ethnographic work on social movements:

Ethnographic analyses of social movements have been most persuasive when they transcend the single organization or single-issue focus of much collective action research in favor of broader examinations of the political and social fields within which mobilizations occur. Although ethnographers have often provided compelling, fine-grained accounts of collective action, they have been less consistent when it comes to developing dynamic analyses of either the larger political contexts in which mobilizations occur or the preexisting militant traditions and the organizing processes that constitute movements' proximate and remote roots. [Edelman 2001:309]

This critique joined the issues I had been considering from Koga's seminar to motivate a new aspect of my research. ${ }^{33}$ Edelman's call for ethnographers to look at activist biographies, the lived experiences of movement participants, and the broader political and social field in which movements emerge (2001:297,309), inspired me to revisit old field notes and begin new conversations. As I spoke with my informants about how the Occupy movement came to Indonesia and about activist histories of engagement with social movements, I also began to look at Indonesia's history more carefully.

\section{The Rise of The New Order}

Indonesian identity, nationalism, and citizenship are partly produced through the claim that a collection of approximately 17,000 islands in the Malaysian archipelago constitutes a nation called Indonesia. However, the boundary that defines present-day Indonesia does not correspond to a traditional culture, state or polity - it was and continues to be inherited from the colonial encounter (Boellstorff 2005). I am interested in the story of Indonesian independence and the rise of the New Order government because they provide historical context for the position of social

33 Along with lectures and discussions in Edelman's seminar on Transnational Social Movements at the CUNY Graduate Center in the spring of 2013. 
movements in Indonesia and the eventual emergence of the Indonesian Occupy movement. Activist posts across multiple Facebook groups echoed Bu Citra's repeated references in the previous chapter to the Sukarno era and the "original" constitution. This speaks to the significance of this history for her as well as the broader Occupy community of practice.

Following the surrender of Japan on August 15, 1945, Indonesian youth leaders (along with Sukarno and others) drafted an independence declaration that was read on August $17 .{ }^{34}$ When allied forces arrived expecting to return Indonesia to the colonial regime, they found a war of independence and a nation divided between left and right, young and old, Islamic and secular, Dutch and Indonesian. In a speech called "The Birth of Pancasila" Sukarno outlined the four ideals behind what he envisioned as the binding national philosophy of the new Indonesian nation - Pancasila:

Kebangsaan Indonesia. (Nationality of Indonesia)

Internasionalisme, - atau peri-kemanusiaan. (Internationalism or Humanity / Humanism)

Mufakat, - atau demukrasi. (Consensus or Democracy)

Kesejahteraan sosial. (Social Welfare).

After five years of revolutionary conflict, factions unified enough to replace a divided state with the Republic of Indonesia under Pancasila and a unitary constitution in 1950. It was during these years that the Indonesian communist party (Partai Komunis Indonesia, PKI) regained strength and built the foundation of what would soon become the world's largest non-ruling communist party. Despite the apparent unity of the nation by the early 1950s, over the next few decades the military, the PKI, and Islamic nationalist separatist movements all struggled for power.

34 Historical events not otherwise cited in this section are from Ricklefs (2001). 
From 1957 to 1965 Sukarno ruled with a philosophy of Demokrasi Terpimpin (Guided Democracy) based on traditional village structures of consensus supplemented with guidance from elders. At the core of his Guided Democracy was an attempt to bring together the factions in Indonesia by blending nasionalisme (nationalism), agama (religion), and komunisme (communism). Sukarno's power and legitimacy as president of the newly independent nation depended on balancing these three forces, especially the tensions between an increasingly antagonistic military (nationalism) and PKI (communism). His successful balancing of these forces led to one of his nicknames Dalang, the word for the Indonesian puppetmaster who performs the Wayang.

In my earliest conversations with Bu Citra, one of the links she sent in a follow-up e-mail was to Sukarno's speech at Yogyakarta (Jogjakarta) from December 1961 announcing his intention to invade and occupy West Papua. The speech opens with Sukarno telling the story of the Dutch occupation of Indonesia and giving a brief history of Indonesian resistance against that occupation:

You know that the Dutch began to come here to Indonesia in 1596, when Admiral Cornelis De Houtman dropped anchor in Banten Bay. Since that time, Friends, Dutch efforts to occupy the whole of Indonesia were always accompanied by force of arms. That is why I say that in fact the Dutch have taken military action against the Indonesian people hundreds of times. And as something for the people of Jogjakarta to be proud of - I say from this rostrum, that it was from the region of Jogjakarta that the first opposition came, fierce opposition against Dutch Imperialism. ${ }^{35}$

In his speech, Sukarno commands the Indonesian military to "liberate West Irian from the strangle-hold of Dutch imperialism." West Irian was at that time the name given by Sukarno to the territory on the island of New Guinea west of the $141^{\circ}$ longitude line. Eighteen days before Sukarno's speech, however on December 1, 1961, the people of that territory raised their own

35 I am using the version that Bu Citra sent me: www.papuaweb.org/goi/pidato/1961-12-jogjakarta.html 
flag and declared independence for their nation of West Papua from Dutch colonial occupiers. In this pre-invasion speech, however, Sukarno offered a different idea of what constituted independent Indonesia's geo-political boundaries and his cartography included West Papua:

The Dutch promised that they would recognize sovereignty over the whole of Indonesia. And, friends, what is it that is called Indonesia? What is called Indonesia is the entire archipelago between Sabang and Merauke. What is called Indonesia is what was formerly referred to as the Dutch East Indies. What is meant by Indonesia is what the Dutch called Nederlands Indië, that entire archipelago between Sabang and Merauke which is composed of thousands of islands. That is what is called Indonesia.

Merauke is the eastern most town in West Papua, just short of the $141^{\circ}$ longitude line and soon after this speech, Sukarno's military began attempts to invade West Papua. Following the signing of the New York Agreement an occupation and genocide began that have continued to the present day. ${ }^{36}$

Bu Citra's decision to send me Sukarno's speech on West Papua draws attention to her interest in the frictions between resistance to Dutch colonial occupation and Indonesia's continuing occupation of West Papua. These interests, shared by many of the Indonesian occupiers, situate their engagements within similar tensions around re-framing the idea of "occupation" that characterize the global Occupy movement. These tensions are echoed in the occupation of Zuccotti Park in New York City and were often brought up through discourse within OWS reminding activists that "Wall St. is on occupied Algonquin land" and asking occupiers to "de-colonize the $99 \% .{ }^{, 37}$ Like Bu Citra's adoption of Sukarno's anti-colonial rhetoric, these anti-colonial critiques from within the movement are an integral component of the Occupy discourse.

36 On August 15, 1962, the Republic of Indonesia and the Kingdom of the Netherlands signed an agreement at United Nations headquarters in New York that transferred the sovereignty of the territory to Indonesia.

37 One example of these phrases come from a poster created by Ernesto Yerena, Orlando Arenas, Sandra Castro and Ricardo Lopez (hechoconganas.com) found online at occuprint.org and also appearing in print in the Occupied Wall Street Journal Issue \#4 (occupiedmedia.us) 
In the early to mid-1960s, Sukarno's rhetoric became more anti-western and the PKI gained more power throughout every level of the government. In his Independence Day speech on August 17th 1965, Sukarno announced an "anti-imperialist Jakarta-Phnom Penh-HanoiBeijing-Pyongyang axis" and implied that only the military was standing in the way of this plan (Ricklefs 2001:338). In response, on September $30^{\text {th }}$ a battalion of palace guards attempted a coup. Major General Suharto took command of the military announcing that he would stop the coup and protect Sukarno, however he then refused to return control of the military.

Weakened as president, Sukarno was forced to transfer powers to Suharto over the course of the next year. Suharto was named president in March 1967 and he established what came to be known as his "New Order" (Orde Baru) in contrast to the "old order" of Sukarno's presidency. During the first year after the coup attempt, Suharto ordered a massacre of PKI members, their families and suspected members - as many as 1 million or more were killed or jailed by the first months of 1966 (Ricklefs 2001:347). Along with the Armenian genocide, the WWII Holocaust, Rwanda, Cambodia, and others, this was one of the largest mass killings of the twentieth century and it remains largely invisible and forgotten within Indonesia today.

When Suharto came to power in 1968 his government overturned Sukarno's antiimperialist policies and began massive "development" projects across Indonesia. His military regime's New Order sought to depoliticized the people and the military presence at all levels of society ensured compliance (Lee 2011). The New Order government worked to transform the rakyat (the people), the everyday people who had been the base for Indonesian independence from Dutch and Japanese colonialism, into a "docile and manipulated" massa (the Masses) (Lee 2011:934). Opposition politics in the 1980s and 1990s therefore involved mainly political elites and the relatively privileged university students in NGOs and universities (Lee 2011). 
Student demonstrations against Suharto persisted through the New Order and the government fought back by instituting assimilationist policies backed by compulsory indoctrination in the state philosophy. The goal of these programs was "ideological homogeneity" (Ricklefs 2001:373). Through these programs, the New Order regime manipulated the power relations inherited from the Indonesian nationalist struggle for independence and used them to prevent rakyat (the people) from becoming populist figures in the reform movement.

\section{Indonesian "Ruins of Empire"}

Ann Stoler's work on imperial formations as relations of contemporary force is useful in thinking about how remains of the 1945 anti-colonial independence movement shaped conditions for the emergence of the 1965 massacre, Suharto's New Order, the 1998 student movement and later the Occupy movement. Stoler (2008) argues that colonial processes are predicated on claims of protecting natural and cultural inheritances for a population assumed to be in need of guidance in order to value and appreciate their inheritance. Investigating "protracted imperial processes" Stoler looks at "imperial formations" as relations of contemporary force evident in the "ruins of empire" and asks: how does colonial history matter? What do people count as remains? And what do they do with these remains (Stoler 2008:192-6)? By asking how people "live with and in ruins" and turning to ruins as "epicenters of renewed claims, as history in a spirited voice" Stoler hopes that such examinations might uncover "new possibilities, bids for entitlement, and unexpected political projects" (Stoler 2008:196-8).

Turning attention to the ruins of empire in Indonesia helps to uncover the complex relationship between divide and conquer techniques of oppression inherited from the Dutch Colonial government and New Order assimilationist policies of ideological homogeneity. In New 
Order Indonesia the ruins of empire both defined the archipelago as a unified nation-state based on boundaries created by the Dutch, and yet also continued to divide the people through a state ideology and policy that officially recognized only certain identities and people as "Indonesian." This effect was felt strongly by Chinese-Indonesians who were targeted in 1965, throughout the New Order and again in 1998. This dual-sided colonial inheritance made a claim to unity and demanded assimilation and homogeneity, but also only recognized free cultural expression and other human rights for members of officially sanctioned communities.

Under Suharto's New Order, Islamic nationalist and separatist movements grew in Aceh and elsewhere, while Indonesia continued to occupy West Papua and East Timor. After gaining independence from the first and longest enduring European overseas empire, Portugal (Power and Sidaway 2005), East Timor was invaded and subject once again to colonial rule. On December 7, 1975 the Indonesian military took control bringing massive human rights violation to the island (Stahn 2001). From 1975 until the late 1990s, the people of East Timor lived under military occupation. From military occupation and repression in West Papua, at the eastern boundary of Indonesia, to the separatist movements in Aceh province on the western boundary of the nation - the ruins of empire and colonial inheritances continued to shape relations of power in Indonesia.

\section{From Reformasi to Occupy: "I was in Jakarta on May 1998 ..."}

When I reached out to Bu Citra in February of 2013 to ask about her history of activism and her memories of the past, I wrote:

Hope everything is going great with you!

One of the things I'm looking at now is how people have been involved in social movements across generations. I wonder, were you in Indonesia during the late 
90s, when the student demonstrations happened? I would love to hear your perspective about that time!

She replied quickly and said only: "Hi there,I was in jakarta. Had a very sad memories.. Will email you soon." When I heard back from her again, seven days later, it was clear that she had taken a great deal of time to write out her story and to carefully describe her memory of May 1998. This was one of the longest, most detailed, and personal of all the e-mails she had sent me since I began talking with her in 2011. She began by telling the specific story of that time, and her memories of a day which center around her family and her concern for her dual-citizen children (American-Indonesian):

I was in Jakarta on May 1998 where the students started the movement new reformation (reformasi) and the result : President Suharto step down.

I was at the north of Jakarta attended a meeting with a taiwan guest (buyer) . At 2 pm we were informed that there was a riot and several students were killed by the military. I rushed back home ( south jakarta ) and was lucky to be able to arrive home and be with my 3 American citizen chldren.

By midnight - things were so brutal and out of control - all expatriates and chineses Indonesian were rushing to the airport to get out of the country. Every one fled the country left their property. All at the airport were willing to give what ever expensive cars they drove that way as long as they got tickets to fly out of Indonesia. Some hired privates boats and gone as soon as they can.

My condition was not better either. US Embassy sent their representative to take my American kids away from me. By American law they must take all their citizen out of the country a.s.a.p - and too bad - that their mother ( me ) is an Indonesian citizen....

3 days later at $4 \mathrm{a}$ m the US Embassy car picked up the children from the house - $\mathrm{i}$ was allow to go with them to the airport to say good bye. A few US airplanes were park at the military airport in Jakarta. No tickets - only names and numbers all US citizen left the country - including [Jennifer], [Patricia] and [Sharon]..... US School closed for uncertain time. The girls left for 3 destination of choice : Singapore, Hongkong or USA. I requested they be sent to Singapore and my friends will look after them over there.[Sharon] was 7 years old....

As far as ALL American children concern they love it - no school from may until after summer - and many friends in singapore to play with.... 
$\mathrm{Bu}$ Citra then continued by broadening her narrative to Indonesian social movements and the meaning of that moment in the 1990s for her understanding of how she fits into contemporary activism and what role, if any, the next generation ought to play:

About Indonesian - if you read the movement in Indonesia - almost all is started with the university students. They the one that are up front and as history tells itself...they ( the students ) that get killed by our own army - this is a repeated history.

One of the active movement during that time ( 1997 - 1998 ) live here in the USA - we were talking how sad it was for them that time to have their friends killed by the Indonesian Army -

That is why now when I read friends complain about the students of not being active in the movement - I defended the students. - My comment is always : do not repeat history - we ( the working class Indonesian ) have to protect our young generation. Their job is to study. If we ( the working class Indonesian ) are not happy with the social and political of Indonesia - we the one that have to be in the front row - we society that have to be the social control of Indonesia - not them. I think - nothing change - the working class of Indonesian either too coward or too comfortable in their new position to go be the social control of the nation.

Indonesian are ideals when they are in the university - and majority will change their view once they graduated and work. The new students of the universities.... will again.... be the social control...

This is my personal opinion base on my personal experiences. Ask me any questions - I will try to answer

I was also a witness of 1965 movement - it was worse........ scary ---- equal or worse than Hitler!.

When Bu Citra says "social control" here - I understand she means the activists, the people who she hopes will hold the government accountable. The memory of 1998 makes her sad, and she is concerned for young people who get involved in activism because of the memory of those who were killed in 1998, but also because of continuing danger. Bu Citra identifies the 1998 protests, along with all post-independence social movements in Indonesia, as started by students. In her current role as an entrepreneur, her marriage to a U.S. citizen and with her ability to travel 
internationally, she sees herself as a "working-class Indonesian" and relates this identity to a responsibility to "be in the front row" of activism in Indonesia today. She sees it as her duty to engage with social and political issues in Indonesia so that young people can be free to study. This inheritance from her experiences of 1998 are part of what motivated her to reach out to friends in Indonesia, also from her generation, to start the Occupy movement there.

\section{New Order Memory and Inheritance}

I replied to Bu Citra's e-mails about 1998 and told her I was still trying to learn more about what happened in 1965 and in 1998 and how these memories affected her. I wondered if those times were on her mind when she saw Occupy Seattle and when she reached out to her friends in Indonesia. Bu Citra replied with a story about her own daughter's curiosity, and a warning for me as a researcher and as a foreigner:

3 weeks ago my daughter [Sharon] asked me : mommy were you aware of 1965 movement? I said ofcourse - I was 8 years old that time. She said REALLY? HOW COME NO ONE IN YOUR FAMILY EVER TOLD ME? I said : you never asked. She was confused why no one ever talked about that movements and she found it out from a dutch friend that writes about it and being black listed from Indonesia now....

I said : well - the reason is simple : one - we have too many dramas in Indonesia actually not dramas - tragedies, We ran out of energies. two - ANYBODY that has connected with the G30S ( 1965 ) movement will be prosecuted including the intermediate families members. Will have NO futures - will not given i.d, and will never held a position in any jobs. And you see your dutch friend, he mingles too deep about 1965 and he is black listed from Indonesia now, I askyo u [Sharon] ( she is graduated in English Literature - Seattle University ) not to get involved in research of it - it is the past - if you wish to research on Indonesia - do the present - movement to educate women of Indonesia. That is the present and will do good for the country.... If anybody wants to work on 1965 let it be an Indonesian ( [Sharon] holds US citizen ) - ( but $i$ think that person will die in the process....) 
$\mathrm{Bu}$ Citra's warning left me feeling uneasy about my hopes for researching social movement history in Indonesia. Her response arrived just as I was waiting for the Indonesian government to approve my visa application. I worried that in an office somewhere a consular officer might have read my articles in which I critique the Indonesian government's oppression of West Papuans, human rights activists and others who fight for justice in the archipelago. I thought perhaps they would deny my visa, or that they would add me to a list, I wondered if I would be under surveillance while in Indonesia. Like $\mathrm{Bu}$ Citra, I started to become afraid of the Indonesian government.

$\mathrm{Bu}$ Citra is afraid of asking questions about 1965, and also about more recent movements, like the 1998 movement that overthrew Suharto. Even so, she sees some kinds of involvement in activism as a risk she is willing to take but not one that her daughter, or other young people like myself should take. At the same time the 1965 massacres were erased from public memory by the New Order regime, they remained as a measure of the possible - as a warning to those who might try and remember. They are part of an inheritance of whitewashing and of fear. Bu Citra's memories of 1965 are connected to her engagement with Occupy and with her memory of 1998, they persist in her memory, and she chose to bring them up when she wrote "I was also a witness of 1965 movement - it was worse........ scary ---- equal or worse than Hitler!.” Bu Citra closed her retelling of her memory of 1998 with an opening of a new story, with an hesitant offer of opening her memory of 1965 , but only in the most intense and extreme terms; through a comparison to the atrocities of WWII.

The previous sections began to explore generational connections in the context of the ruins of empire - another aspect of those ruins are these memories and inheritances. I use the words memory and inheritance to point to the ways in which history is not only a past for the 
Occupy activists, but a present. The call for change is also a call to remember and remake - a call to make memory contemporary, to make history present again by recognizing the many forms of memory and inheritance. What happens when the past is brought to bear on the present in hopes of asking people to remember? My approach to unpacking memory is inspired here by Stoler and Strassler's writing on memory work in New Order Java in which they consider "what might be gained by making memory-work the subject rather than a given of colonial analysis" (2000:5)

One afternoon in East Java I was talking to fellow students at Universitas Negeri Malang (UM) during our break from class. We were enjoying the coffee and makan kecil (literally: small food) set out for us during the break when Mas Adam, a young man from New York who was also studying Bahasa Indonesia said he had a cerita (a narrative story) to share with me during the next break that he thought I would be interested in. Mas Adam was an undergraduate student at a small liberal arts college back in the United States, and had grown up in urban New York. We returned to our respective classrooms, and during the next break he told me about a police raid at one of the bars frequented by UM students and ex-pats. He said that Houtenhand, a local bar, had attempted to screen a documentary film about the 1965 massacres, "The Act of Killing" (Oppenheimer, et al. 2012) but the police shut down the screening. I e-mailed Mas Adam, who is still studying in East Java, to get his recollection:

I first caught onto it when I saw this tweet from the director, Joshua Oppenheimer: https://twitter.com/JoshuaOppenheim/status/303086803177574401 . I connected the dots when I saw a facebook event for that date at the Houtenhand, and I later got confirmation from who I'm pretty sure was [Riya]. I don't have much more detail than that, but I assume the police came up with a bullshit reason like not having a permit or something. That's what the pemerintah did when they destroyed the synagogue in Surabaya, and the tactic seems to be the broom of choice for sweeping things under the rug.

What I can report is that I've watched the film with some miscellaneous tutors and gurus and they didn't seem to take it with the heaviness you might expect. 
They laughed with the jokes of the killers, and talked through the most sobering scenes. It definitely wouldn't have been socially acceptable to come off looking reflective.

I reached out to our mutual friend Mbak Riya in East Java, also a young university student who had taught herself almost flawless spoken colloquial English, and asked her about the situation with respect to the film, she replied:

Basically, The Act of Killing now can be legally downloaded from its official website, actofkilling.com but as far as I know there are some restrictions in the soil of Indonesia. People can download it but not allowed to show it in groups in public. So if you want to watch it, it is totally ok as long as you do not organize a crowd to watch it in public places. So, if there are people try to organize a screening in Houtenhand, then the police definitely will shut it down.

Oppenheimer's tweet mentioned by Mas Adam was a repost via Facebook of a status update from The Act of Killing Facebook page. ${ }^{38}$ The status reads "A screening of THE ACT OF KILLING in Javanese city of Malang was cancelled by the police. Shame on them." The film has a website in Indonesian, and also a separate Facebook group for the film in Indonesian, and links to the film were shared by users on the Indonesian Occupy Facebook groups and pages.

Field Notes - August 23, 2013 (Malang, East Java):

My host father said UM was becoming what they call a "Green University" meaning that the campus population was becoming more Muslim, and the university administration and academic life was reflecting this change. I was also told by several informants that the mosque on campus was one of the more conservative in the area. An interesting fact considering the way that this mosque occupied an important role in the student's lives whom I was friends with. My tutor Adi would pray five times each day, and this often meant going to the mosque on campus when he was there for school, or to work with me.

For my final project, I presented on the Indonesian Occupy movement specifically on the language they used. My topic was how the indonesian social movement adopted the globalizing Occupy discourse using the word Occupy rather than the Indonesian word Duduki. After the project, I was approached by a student at the university (Ahmed), I believe an S2 (M.A.) student who told me he wanted to know more about my research. He expressed interest in my paper

38 www.facebook.com/actofkilling 
which I sent to him, and also wanted to tell me about his thoughts on the movement. He said that when he had talked about Occupy with colleagues at the university they had called him a "traitor." He agreed to talk to me more about the movement in the future and I look forward to interviewing him.

As I write about Bu Citra's memories of 1965 and 1998, I also try to understand what it means for her to remember, what she has inherited, and how she is bringing memory to her relationship with her daughter. These issues bring me back to the reading and discussions in Koga's seminar about what it means to be a survivor, how victim and survivor narratives are constructed, and what later generations inherit from those experiences. As I consider the release of "The Act of Killing" and how Indonesians are responding to this activist film that aims to work directly in the realm of memory, I wonder about the role that media (film, social media, news media, and others) have in producing survivor and victim narratives. Also coming to mind here are Yoneyama's work on Hiroshima survivor identity in relation to testimonial practices (1999), and Derrida's writing on forgiveness and reconciliation (2001), both of which we read in Koga's seminar.

Field Notes - October 19, 2012 (New York): e-mail sent to Yukiko Koga

I've been reading Stoler's Imperial Debris as you suggested, and it's really useful. A lot of the other work I've been reading seems interested in finding unity across the nation, dealing with an Indonesian subject, where a previous generation had looked at it more ethnolocally, like only Java or only Bali or even smaller. But in that turn toward the unity and in looking for similitude, there seems to be failure to account for what thinking of as a colonial echo (producing both divisions and unity in different ways) - and Stoler's imperial debris lens is helpful in reframing that. Just now getting into the article, and giving it lots of time and a careful reading as you suggested.

$[\ldots]$ 
The Agamben we read in Law was hugely inspiring for me along with your work, which was unlike anything I'd heard about before. Everything around the areas of empire, colonial legacy, state power and its effects on people as well as their collective and personal responses to it - and around questions of human rights, justice, etc. Prior to adding the anthro major, I was focused on looking at social justice through the intersections of religion and technology and this usually meant looking at social movements which were organized around responses to injustice. I wrote about Burma and about Foxcon factory workers in China, etc. - the liberating promise of the technology they are manufacturing in contrast to their experiences as subjects of the factory life, etc. So I think that's these issues are the constant thread through it all.

Koga writes about the "the unfinished project of unmaking the Japanese empire" and how relations and interactions between victims, states, and delayed legal processes produce a complex attempt at accounting for violence (Koga 2013:484). Her analysis of the resulting moral economy and the processes involved inspired me to re-consider the Indonesian memory of and attempts to account for the New Order era violence. Koga looks at how "long-deferred attempts to account for Japanese colonial violence" result in more violence inflicted on the postwar generation (Koga 2013:500). In light of these ideas, I wonder what the consequences will be as Indonesian activists like $\mathrm{Bu}$ Citra continue to defer memory and investigation, and pass these deferrals on to her daughter's generation.

When Bu Citra's daughter asked her about the 1965 massacres and why she had never told them about this history Bu Citra explained that she had never told her because she "never asked." $\mathrm{Bu}$ Citra's daughter instead learned about the massacres from a Dutch friend, a researcher from the former colonizing nation. Bu Citra explains that this Dutch researcher is now blacklisted in Indonesia because of his interest in researching 1965. The colonizer is both rejected by Indonesia at Independence, and again when the colonizer's descendant attempts to study continuing histories of violence. It seems that to accept Indonesian independence as a 
break with the colonial, and the idea of an Indonesian nation is to reject not only the colonial power of the Dutch, Japanese, and others, but to continue to reject all formulations of history which have the potential to frame any occurrence in Indonesia as resulting from colonial power relations or inheritances of those relations. This cycle of forgetting implicates any effort to uncover victim's and survivor's histories of the New Order (and other colonial inheritances that continue to shape power relations in Indonesia) into the same rejected colonial power relations such investigations seek to uncover and expose.

Another of the informants I asked about Occupy and history in Indonesia was my friend Mas Adi, who was finishing a degree in English at UM. Mas Adi was in his mid-twenties and a dedicated student. He had grown up outside of the city in a farming community where his extended family still lived. He was also my language tutor while I was studying in Indonesia and we spent many afternoons together walking across the lush, green campus - or going out into the small alleys of the kampung to run errands while he taught me how to avoid the ever-present danger of motorbike-chaos that defines Southeast Asian streets. I asked him these questions by email, which are reproduced here in bold with his unedited responses:

\section{When did you first hear about the Occupy movement or Occupy Wall Street?}

I didn't about it until you talk to me when you did your research on facebook here, though I heard that Wall Street had several crisis, such as financial issue several years ago, for me, this movement is quite new, maybe this past 2 or 3 months

\section{What do you think of the Occupy movement in Indonesia? Occupy Jakarta, Occupy Freeport, for example?}

I think it is a big thing to do. Jakarta of Freeport is not the only place which has complicated problem. Occupying a place doesn't guarantee that the situation will change to be better. Rather than tooccupy, why don't the activist of the movement try the bigger step, such as infiltrate the government and change everything from the top, OR they can do it to gain sympathy from the public through internet (hacking government's site for example) or people movement, though I feel that it is not enough to change everything. 


\begin{abstract}
What issues do you think are the most important for Indonesia right now? Moral issues of the civilian, because even if we have the best leader in the world, it won't help a lot to make this country to be better. From the grass root to the top, everyone corrupts, in every aspect of bureaucracy.

Second, now Indonesia is wating for its next president, so everyone hopes for the best for this person we are too tired with a weak and bad leader.

Last, is education. Indonesia has lots of potential resources and man power, if we can manage them well through education, we can be a bigger and leading country in the world
\end{abstract}

\title{
Do you think that social movements (protest, activism, groups) can make changes for Indonesia, or is it better to use democracy, or better to have a different system?
}

I don't think it will give a big difference here. Money talks. People do crime even when public and lots of people know it. There is no shame on them, they don't care what people say, and these kind of movements are not really effective against them. Actually democracy is already good, IF it is followed by GOOD moral of the people who use it or are involved in it

\section{What do you think the biggest differences are between these times in Indonesia: Before 1945, Before 1965, Before 1998?}

All are the key moments in Indonesia history, but since I live on 1998 era, so I know the effect well. The regime of Suharto fell down, followed by democratic election where we can choose our own figure to be president, yes indeed it gives a huge shift of politics in Indonesia

Mas Adi, like most Indonesians I spoke with in person had never heard of Occupy Wall Street, or the globalizing Occupy movement. Instead of "occupation" he proposes what he sees as a more effective solution - working from within the system. Yet at the same time he acknowledges that from the grass roots to the top everyone is corrupt. His recognition of the level of corruption in Indonesia extends to his analysis of the usefulness of protest - he does not see it as an effective strategy in a place where financial power and the corruption it fuels are greater than the power of civil society.

Despite our friendship, and his knowledge of the events, he chooses not to discuss or even respond to my mention of 1965 instead focusing on 1998 and later, the post-reformasi period. Even in his description of Indonesia post-1998 he suggests democratic elections followed 
even though they didn't occur until 2004. In most of my conversations with Indonesians from this generation, both those involved with Occupy and those who had never heard of the movement did not say much about 1965. Compared to Bu Citra's memories and stories, Mas Adi's answers struck me as empty and reflective of the New Order whitewashing. In reading his responses I feel as though the danger, fear, and chaos - the personal threat of Bu Citra's historical Indonesia - has been painted over Mas Adi's ideas of history with so many layers that only the dates remain.

I wonder about this insistence not to speak in any detail, either personal or historical about the violence of the 1965 massacres and other events of the New Order era. In my conversations with younger Indonesians, I came to feel that gracefully avoiding questions about topics such as 1965, Papua, and Timor was an art form in East Java. Those few who spoke to me openly about such things were either perceived as traitors or social outcasts, or as in the case of $\mathrm{Bu}$ Citra and others, were an older generation of activists. But as with Bu Citra, that older generation does not want their children to know what happened in 1965, and they respond negatively to attempts to investigate, almost as though even just asking is an act of betrayal.

Koga draws on Derrida to flesh-out and suggest a framework for thinking about how inheritance opens up a possibility of betrayal, writing:

As Jacques Derrida points out, inheritance is more than a simple transfer of capital from one generation to another; secrets inherent in inheritance open up a possibility of betrayal. What one inherits is opaque, with layers of histories written on it, yet one has no choice but to inherit (Derrida 1994). Derrida alludes to a threefold usage of the term betrayal which illuminates the logic of inheritance. One usage is the conventional meaning of betrayal as an act of treason and disloyalty. The second refers to the act of revealing, disclosing, showing or exhibiting. The third refers to the act of disclosing or revealing what should be kept secret. Owing to the multiplicity of the past that inheritance embodies, displaying inheritance could result in an act of disloyalty and denunciation by revealing what is supposed to be unseen. [. . .] Capitalizing on inheritance by exposing what has long been invisible through restoration is 
accompanied by an unexpected excess that disturbs long-held narratives of the past. [Koga 2008:223]

While Koga is writing here about architecture and restoration - the framework for considering inheritance is still useful. Indonesian reluctance to discuss specific areas of the past, and the reactions of Indonesian police and university students to "The Act of Killing" suggest an inheritance involving all three aspects of betrayal that Koga finds in Derrida.

The premise and justification of the massacre in 1965 was betrayal; communists were murdered by Suharto's regime because of perceived disloyalty (and perceived alternate and incompatible loyalties to Communism and/or China). Attempts by the bar in East Java to screen the film was perceived as a threat to disclose, to exhibit and show - and was therefore stopped by the police. The police reaction to the attempted screening shows that 45 years after the massacre and 16 years after the fall of the regime that worked against memory to keep it silent, the perceived necessity of invisibility is a persistent force. Bu Citra fears the consequences for her daughter of discussions and investigations into what is supposed to remain un-discussed. The police fear exhibition and revelation of what is supposed to remain un-shown and un-seen. Attempts to engage with the past, from many angles, are each selectively seen as forms of betrayal and sites of potential danger for the transgressor.

In my conversations with East Javanese students, they seemed to perceive attempts to come to terms with the past as anti-Indonesian. Nationalism in Indonesia is historically based on anti-colonialism, following post-colonial independence from the Dutch and Japanese occupations. The anti-Sukarno, pro-western New Order, however, transformed Independence era anti-colonialism. To question the processes that first made Indonesia an independent nation-state, and then brought development and international relationships, brings to memory the colonial relations that first defined these islands in the Malaysian Archipelago as a region called 
Indonesia - as well as the work of the New Order to maintain the nationalist discourse while stripping it of its anti-colonial rhetoric.

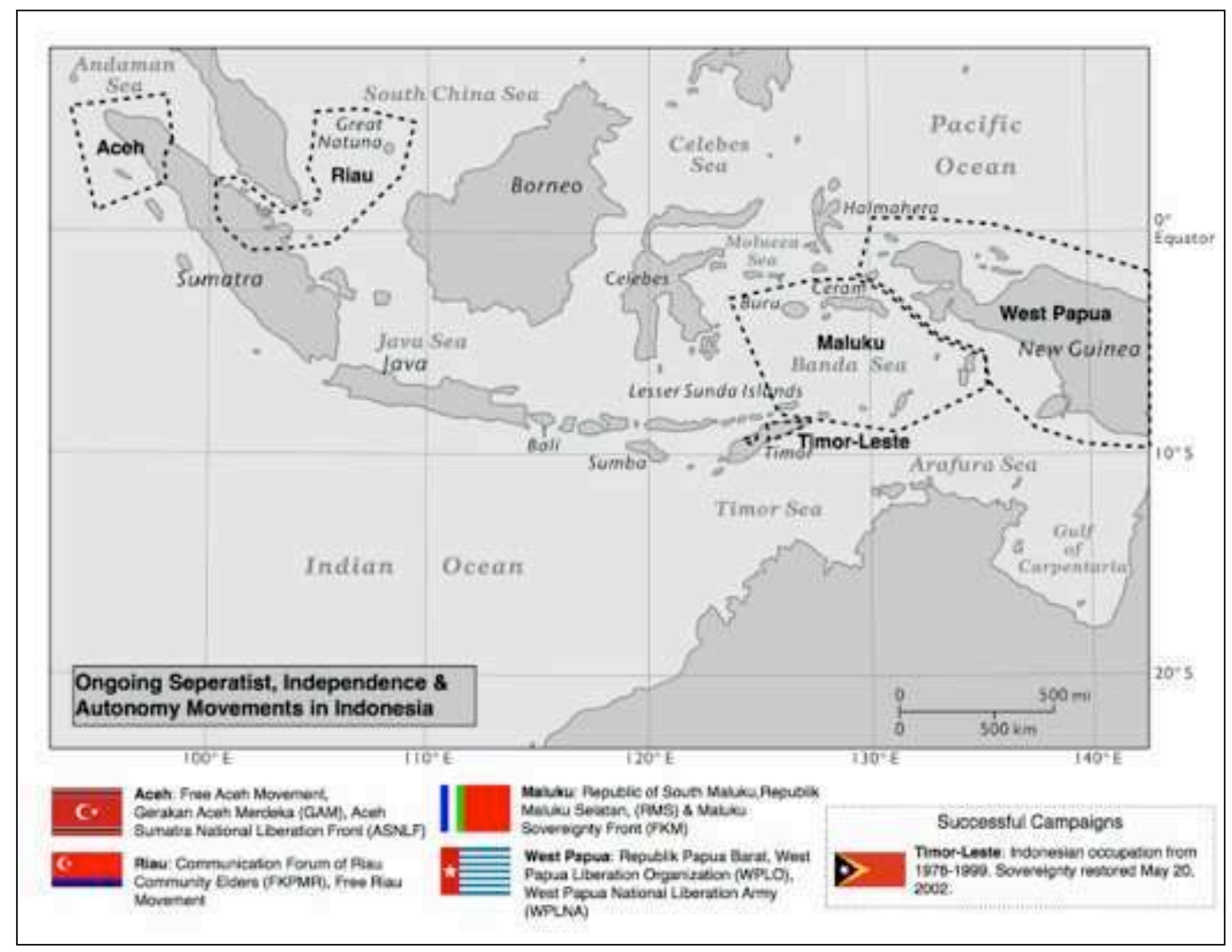

Figure 12: Map of separatist, independence, and autonomy movements.

The declaration of Indonesian independence in 1945 relied on an Indonesian identity created in part by the mutually producing colonial relationships, and in the ruins of the earlier colonial era Sukarno and later Suharto produced dual sides of a discourse of unity that continues to struggle for legitimacy today. This, in part, explains how activists aligned with independence and sovereignty movements have easily found a home under the anti-colonial, anti-imperialist banner of the Occupy movement; such as the Aceh independence movement, the Free Papua movement, and others (Figure 12). Claims to independence, claims for economic freedom, claims for indigenous rights - all have the potential to be perceived in Indonesia as acts of disloyalty because they reaffirm that complex of issues Koga calls debts of inheritance - they remind, 
expose, and ultimately betray the naturalized notion of an Indonesian state free of colonial inheritances and encumbrances. These autonomy and independence movements also echo and bring back Sukarno's anti-imperialist rhetoric, which the New Order first worked to frame as against the best interests of the nation (despite its role in creating an independent Indonesia) and then to erase from memory and make invisible.

In attempting to understand Indonesian Occupy activist relationships with the colonial and New Order past, I looked for answers in memories around national events in 1945, 1965, and 1998. However, as Stoler and Strassler point out:

The assumption is that subaltern narratives contain trenchant political critiques of the colonial order and its postcolonial effects. But this commitment may generate analytic frames less useful for understanding memories that are not about nationally salient events, memories unadorned with adversaries and heroes, compelling plots or violent struggles. Such focus on event-centered memory may, in fact, block precisely those enduring sentiments and sensibilities that cast a much longer shadow over people's lives and what they choose to remember and tell about them. [Stoler and Strassler 2000:8]

Although Stoler and Strassler's interviews and fieldwork took place when the New Order regime was fully entrenched and my interviews and fieldwork took place 15 years after the end of the New Order, I still found no coherent narrative about the colonial in my informant's stories, no subaltern voice reaching back to a dialogue with the New Order and the colonial era. Instead, I too found only an "occasional clarity" from informants who were "keenly aware that telling the past has political stakes" (Stoler and Strassler 2000:12) as well as personal consequences.

Each time Bu Citra told me her stories of activism and memories of history, she chose to focus on her relationship with her family. Of greatest importance in telling these stories was her children's well being in the face of danger. She tells the story of her family being torn apart, temporarily, by the 1998 student movement that brought down Suharto's New Order. She later spoke again about concern for her daughter in light of her daughter's interest in researching 
1965. Bu Citra's memories of the New Order and its end continue to motivate her activism on the one hand with its focus on a return to Sukarno-era politics, and on the other hand demonstrate her desire to protect her family and find safety from the forces that she repeatedly saw working in Indonesia.

Like other Indonesians I came to know, Bu Citra wants both freedom and safety, both revolution and protection - and her life is ongoing within memories of the effects of, but without clear lines separating the colonial and postcolonial, the New Order and Reformasi periods. She does, however, want this line to be drawn for her daughter. As Bu Citra said, clarifying why she had not yet shared memories of 1965 with her daughter:

the reason is simple : one - we have too many dramas in Indonesia - actually not dramas - tragedies, We ran out of energies. two - ANYBODY that has connected with the G30S ( 1965 ) movement will be prosecuted including the intermediate families members.

She bears the weight of remembering and continuing to live with these memories and considers that burden to be her responsibility, not a role she wants to pass down. As she says to her daughter "if you wish to research on Indonesia - do the present." 


\section{Part III. OCCUPYING FREEPORT}

For many oral indigenous peoples, the boundaries enacted by their languages are more like permeable membranes binding the people to their particular terrains, rather than barriers walling them off from the land.

- David Abram ${ }^{39}$

\section{Occupying Occupied Papua}

As I scrolled through the walls of Facebook groups, reading posts and clicking-through to users' profile pages I encountered powerful images posted by activists tying the emerging global Occupy movement to contemporary Indonesian anti-corruption, anti-colonialist, and anticapitalist activism. In one photograph, posted to Facebook on October 20th, a protester sits on the ground and holds up a sign in front of her, obscuring her face from the camera (Figure 13).

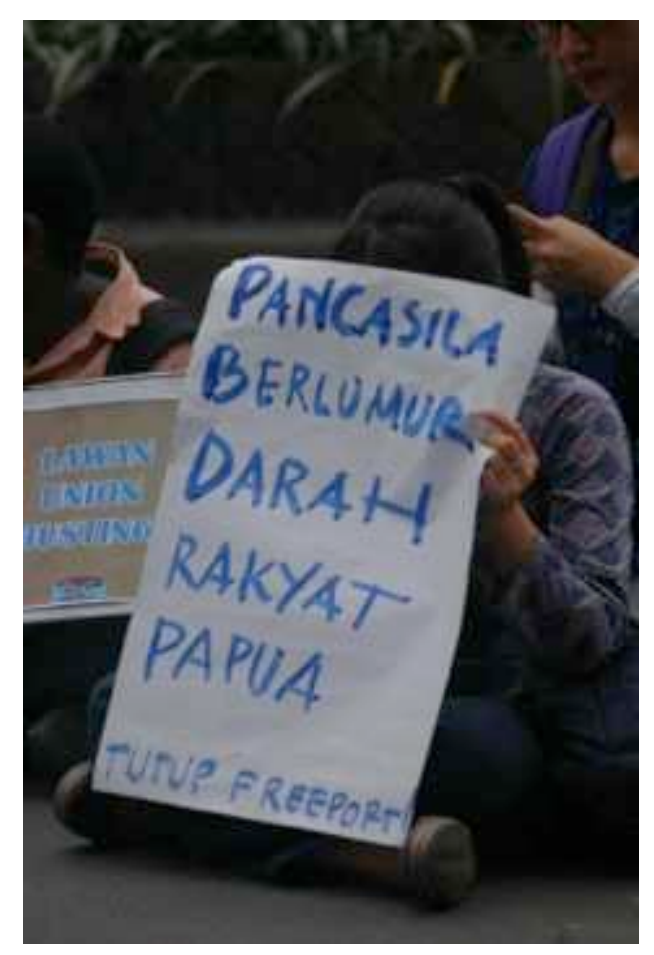

Figure 13: West Papua protest sign and activists.

The sign is filled with hand-written text in large marker-scrawled words:

39 The Spell of the Sensuous (1997:256) 


$\begin{array}{ll}\text { PANCASILA } & \text { [pancasila] }^{40} \\ \text { BERLUMUR } & \text { [smeared] } \\ \text { DARAH } & \text { [blood] } \\ \text { RAKYAT } & \text { [people] } \\ \text { PAPUA } & \text { [papuan] } \\ \text { TUTUP FREEPORT } & \text { [close Freeport] }\end{array}$

The meaning is powerfully clear even in a literal word-for-word translation: "Indonesia's national values are smeared with the blood of the Papuan people. Close Freeport." This was the first reference to "Freeport" that I encountered. I soon learned that Freeport-McMoRan is one of the world's largest producers of gold and the producer of the lowest cost copper. Headquartered in Phoenix, Arizona and traded on Wall Street, this U.S. corporation has also been the largest single tax-payer to the Indonesian government (Tsing 2005:72). Freeport owns Grasberg mine, the world's largest gold mine and the world's third largest copper mine. Located in West Papua, "Freeport," as both the mine and the company are known, is the most profitable mine in the world. This sign was one of many posts, pages, and other acts suggesting connections between local struggles for social justice on the ground in Indonesia and the critique of Wall Street at Zuccotti Park in New York City.

The image also reveals a woman sitting with other protestors, they are occupying in the sense of sitting-in, duduki - but she is also occupying in a new sense of Occupy. She occupies by challenging the silences in permitted street demonstrations, the silences of the Indonesian government, and the silences of the U.S. government around cultural and environmental destruction by resource extraction corporations in West Papua. She is challenging the history of colonialism in the Malaysian Archipelago broadly, and the new colonialism of the independent post-colonial Indonesian state on indigenous and Papuan land. As an Occupier, she makes the Indonesian government's occupation visible.

40 "Pancasila" refers to the philosophical foundations of the Indonesian state set forth in the 1945 constitution. 
By posting an image of this protestor, Indonesian occupiers use Facebook to challenge not only the profiteering of a U.S. mining company, but the Indonesian government's claim on West Papua. The sign draws a direct relationship between the blood of the Papuan people who fight for independence from the Indonesian state, the actions of a Wall Street corporation in Indonesia, and the current governments of Indonesia and the United States. The activist shields herself with the sign, hiding her face from the camera, but her courage to demonstrate in this dangerous situation is recognized by the online Occupy movement. They share the photo in order to say that to Occupy is to bring attention to injustice despite the risks.

Activists calling for Papuan self-determination are seen by the government of Indonesia as threatening both the philosophical and financial legitimacy of the state because the Freeport mine, on occupied Papuan land (occupied in the colonial sense), provides tax revenue that ensures the survival of the Indonesian state. Freeport is also a historical site of conflict around the questions of European and North American colonial activity in Indonesia. One month after the coup that toppled Sukarno, Suharto's New Order began official negotiations with Freeport (Leith 2003:2) for corporate control of the land.

The purported goal of U.S. support for Indonesia's anti-terrorism efforts today is to protect the processes of post-Suharto secularization and democratization, however the "War on Terror" has given political license and material support to the Indonesian governments' efforts to silence dissent, especially around the issue of Papua. West Papua and Freeport have thus become sites where U.S. support for the post-Suharto Indonesian government serves to maintain colonial relations of power. The Indonesian Occupy activists are keenly aware of these connections between U.S. material support of Indonesian security forces and the use of those forces and U.S. technologies to protect Freeport mine as well as other resource extraction sites in the region. 
In his book The Audacity of Hope, Barack Obama writes that "for the past 60 years the fate of [Indonesia] has been directly tied to US foreign policy," including "the tolerance and occasional encouragement of tyranny, corruption, and environmental degradation when it served our interests" (Obama 2006:161). Indonesian activists make a point of drawing attention to this relationship, and of how it continued under Obama's presidency. When the global Occupy movement reached Indonesia, Indonesian Facebook groups immediately brought attention to the environmental and cultural destruction perpetrated by Freeport and the relevance of this issue to the anti-corporate, anti-corruption message of OWS. Although activism around Freeport has a long history in Indonesia, media reports in Indonesia quickly re-contextualized Freeport-related actions as Occupy movement activity. However, in Indonesia, attempts at occupation in physical space can have deadly consequences. On October 26, 2011 globalpost.com described an action by Freeport workers as an "Occupy Wall Street-style" protest. ${ }^{41}$ The Freeport workers had been on strike since September 15 and a clash with security forces near the mine left at least four dead.

\section{Resource Extraction and Indigenous Voice}

On November 2, 2011, a new Facebook group named "Occupy Freeport" emerged. ${ }^{42}$ The first post on the group page was a photograph of Grasberg mine (Freeport mine) - a huge circular pit, carved in steps out of the center of the highest mountains in West Papua. The devastation and environmental destruction caused by Freeport mine becomes visible in an aerial shot (Figure 14). ${ }^{43}$ At first, it is difficult to understand how large the mine really is until one looks carefully at

\footnotetext{
41 www.globalpost.com/dispatch/news/regions/asia-pacific/indonesia/111017/occupy-wall-street-protest-indonesiafreeport-gold-copper-mine

42 www.facebook.com/OCCUPY.FREEPORT

43 Photograph from: dumexpasaribu.wordpress.com/papua-2006/grasberg-mine-area-01/
} 
the scale of the surviving mountains beside it and the small specks on the shelves in the mine, which are actually huge ore mining trucks weighing as much as $1,375,000 \mathrm{lbs}(623,690 \mathrm{~kg})$.

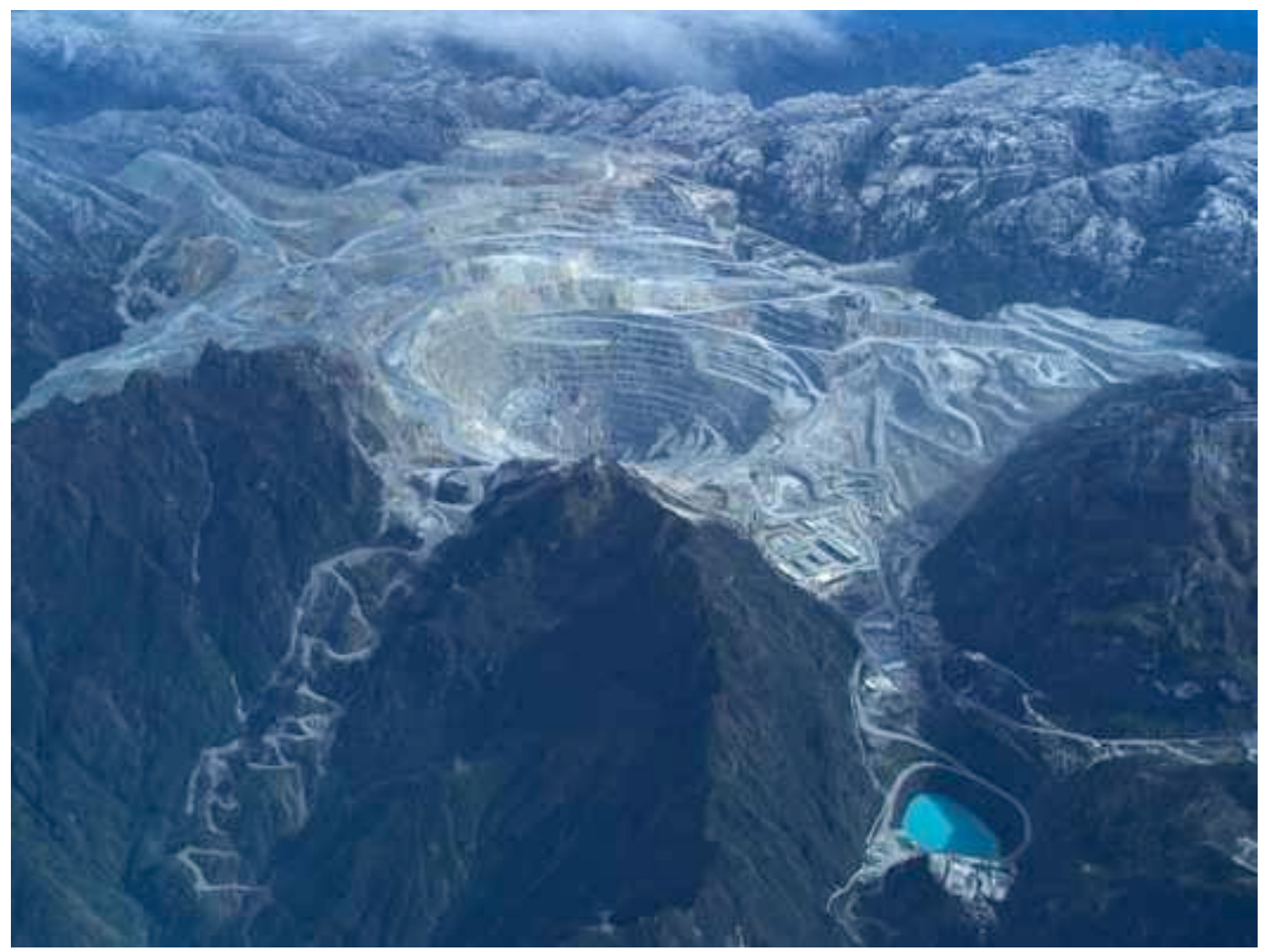

Figure 14: Grasberg mine, West Papua.

The iconic image of this enormous pit, of the gutted mountain, was posted on this page to inaugurate the Occupy Freeport Facebook group and it stands as a testimonial to everything wrong with Freeport. The brutal destruction of the mountain, a scar left by the industrial processes of ore resource extraction, is a compelling image for the cause. By deploying this imagery prominently throughout the Facebook groups, activists show that to Occupy Freeport is to make this destruction visible, and to ensure that the corporations and nations responsible also see that others have seen it. This is also occupation as testimony.

Freeport mine is an industrial strip mining operation on land historically considered the territory of several indigenous communities whose traditional areas overlap. One of these groups, 
the Amungme, consider mountains to be the most sacred part of their mother earth (equivalent to her head) and refer to mountains as the home of their ancestors' spirits (Sarwono 1998:353-54). This holds true even after conversion of many Amungme to Christianity (Sarwono 1998:353-54). In the Amungme worldview, reciprocity in human-nature relationships is necessary for maintaining the well-being of the people and failure to do so threatens prosperity, fertility and happiness (Sarwono 1998:353-54). From this perspective, the destruction of the top of this mountain is the destruction of Mother Earth's head, and therefore also the destruction of Amungme society. From this indigenous perspective, Freeport-McMoRan's resource extraction practices are not merely unjust, or environmentally destructive - they are genocide.

The site of Freeport mine can be imagined from several perspectives. From the current Indonesian government's vantage, the site is a mine located in the Indonesian province of Papua and is a wildly successful joint venture with powerful corporate and state allies. For FreeportMcMoRan, the site is miraculous gift given to the corporation by the government's Contract of Work (the very first permit granted for mineral extraction in Indonesia), which wrote away all local rights to the land with the stroke of a pen (Tsing 2005:69-72). From one indigenous perspective, the land is the site of 45 years of theft by an occupying government working with foreign corporations to slowly and methodically decapitate their sacred mother, to gut and destroy the terrain of her body, to mine and dig up the location where their ancestors' spirits reside.

In 1995, an Amungme community leader was quoted in the Indonesian newspaper, Kompas, speaking about the theft and destruction:

What do they think the Amungme are? Human? Half-human? Or not human at all? If we were seen as human ... they would not take the most valued property of the Amungme, just as we have never wanted to take the property of others.... I sometimes wonder, whose actions are more primitive? [Walton 2004:24-25] 
The indigenous perspective is not, however, a homogeneous view. At Freeport mine, workers descended from the traditional landholders are now employed by Freeport-McMoRan and some support and defend their employer. As a result of the Contract of Work granted to Freeport, the corporation was given the ability to seize indigenous land, relocate people without compensation and use all the natural resources of the area without limit. In this environment, it is no wonder that some indigenous people are left with no choice but employment working in the very mine that threatens their people and culture. ${ }^{44}$ Despite decades of lobbying by human rights organizations and calls from within the Indonesian government to re-negotiate Freeport's contract, as well as calls from Papua's tribal council to close Freeport, the company continues to wield its influence within the new reformed and democratic post-Reformasi Indonesia (RifaiHasan 2009:138). The power of this influence is not surprising when considered in light of the estimated $\$ 4.4$ billion Freeport-McMoRan contributed to the Indonesian government between 1973 and 2005 (Rifai-Hasan 2009:137). In addition, through a campaign to undermine the efforts of environmental, human rights and social justice NGOs working in West Papua, and prevent the NGOs from getting much needed eye-witness testimony, Freeport-McMoRan has established foundations "representing" each tribe living within the Freeport mine area, essentially bribing the people into silence (Hafild 2005).

Online Occupy movement activists adopting the cause of West Papua use a framework in which resistance is framed as a naturalized indigenous activity. As I read their statements about Freeport, I am reminded of Judith Butler's talk at the "Power of Religion in the Public Sphere" symposium at Cooper Union in New York City in which she argued that "[. . .] the public criticism of state violence [. . .] is in some sense a Jewish thing to do" (Habermas, et. al.

44 For more on the transformation of tribal economies into wage labor economies on New Guinea see Imbun (2000). 
2011:73). In these examples of constructing a Papuan "indigenous voice," public criticism and resistance to Indonesian colonial state violence also come to be expected as an indigenous thing to do. This is just one part of what it is to be "indigenous" in Indonesia.

Anna Tsing (2007) looks at claims about the "indigenous" by activists, community leaders, and public intellectuals to follow the discursive frames constructed by those claims. She traces the effect of these frames on the genre conventions which articulate indigenous identity and contribute to the shape of the notion of "indigenous voice." Tsing offers a critique of two common research models used in evaluating indiginiety: case studies and generalizations. Case studies, she argues, string together cases with an assumption of commonality, and analysis looks for universal principles without attention to the specific. Both models, Tsing argues, reduce indigeniety to a "singular set of logics and dilemmas." To counter these models, Tsing seeks a historically situated history of the diversity of the indigenous. This framework for considering indigenous voice is well suited to understanding the intersections of the local and global Occupy movement in Indonesia with indigenous social justice activism.

In Indonesia, the phrase used to refer to "indigenous people" is masyarakat adat (customary society). The official motto of Indonesia, Bhinneka Tunggal Ika, usually translated as "unity in diversity" is a reference to the national identity uniting the Indonesian people despite ethnic, linguistic, and other differences. A related concept, Persatuan Indonesia (Unity of Indonesia) serves as the third principle of Pancasila, the philosophical foundation of the Indonesian state laid out in the 1945 constitution. As reflected in Sukarno's 1961 speech on the issue of West Papua discussed in Chapter 2, this philosophy creates nationalist opposition to distinguishing populations of indigenous people from other Indonesians. Historically, this principle was important to Indonesians as a means of fighting the "divide and conquer" methods 
of imperial and colonial regimes (Tsing 2007). Under Dutch colonial rule, adat (custom/customary/traditional ideology) was elevated to the status of law, and used to frame indigenous cultures and their practices as traditional and natural in opposition to Islam, which was positioned as an invading religion and culture (Tsing 2007).

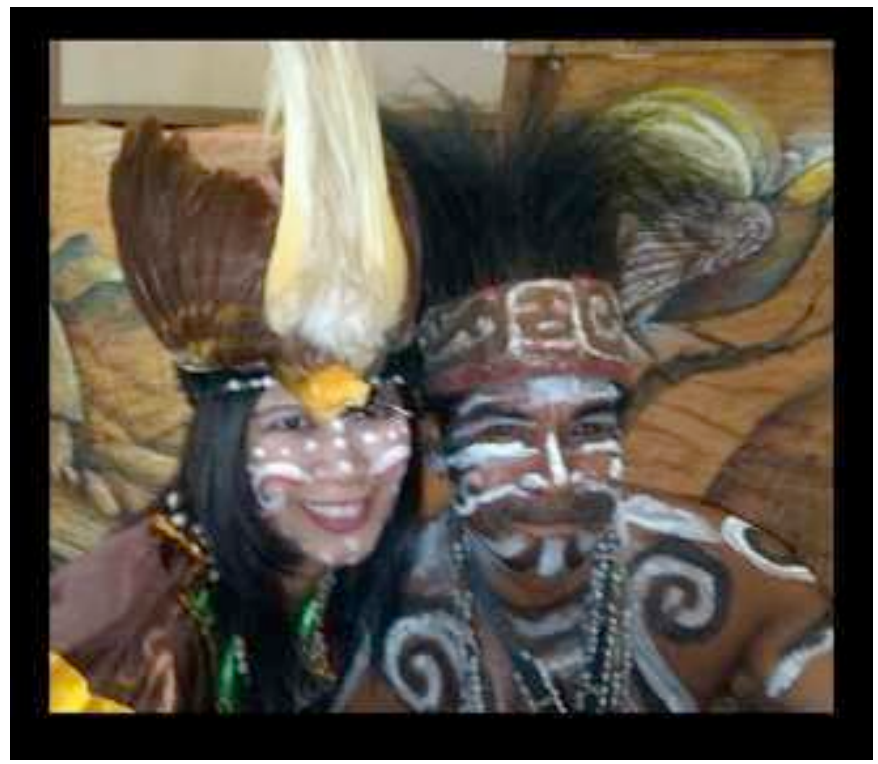

Figure 15: Occupier in Papuan costume (left) with Papuan activist (right).

The first national meeting of Indonesian Indigenous People was held in 1999, when the Aliansi Masyarakat Adat Nusantara ${ }^{45}$ (AMAN) was formed (Tsing 2007). While AMAN works to include indigenous people's of Indonesia in international indigenous movements, some West Papuan activists instead seek independence from Indonesia, rather than rights or sovereignty within the nation state (Tsing 2007). This can lead to tensions between those seeking to "Free Papua" and those interested in reforms within an Indonesian West Papua.

One Indonesian activist explained her definition of masyarakat adat (indigenous people of Indonesia) as: "rural communities fighting resource corporations" (Tsing 2007:37). This broad definition demonstrates the expanded notion of "indigenous" in use by activists in Indonesia.

45 Translation: Alliance of Indigenous Peoples of the Archipelago 
This same meaning is reflected in the use of indigenous identity in Occupy Facebook groups where non-masyarakat adat people take on West Papuan traditional costume in solidarity (Figure 15), demonstrating they too are "masyarakat adat" - they too are part of a community of people fighting colonization, resource extraction, and environmental destruction.

Tsing also addresses the tensions arising when indigenous peoples are themselves resource corporations (those involved in the U.S. Alaska Native Claims Act, for example) and as others mimic nation states (such as the Greenland Home Rule). In light of these tensions, Tsing looks at how global indigeniety is linked to social justice environmentalism, an especially useful framework when considering the globalizing Occupy movement and activism around West Papua. Across Papua, mining companies employ applied anthropologists to collect data on the environmental impact of illegal mining by indigenous people. This data then serves as part of a ploy to shift the blame of environmental destruction away from corporate mining and onto smallscale miners who are also original land-owners. ${ }^{46}$ Transnational engagements among indigenous social movements may put such landholders in a better position to combat these strategies.

Tsing (2007) argues that transnational links between indigenous people on the basis of environmental concerns build indigenous definitional frames. In one example from the $1980 \mathrm{~s}$, Brazilian indigenous environmentalists translated their campaign to save the Amazonian rainforest to Southeast Asia giving rise to a globalized rainforest campaign which afforded indigenous people around the world an opportunity to take on the role of environmental stewards (Tsing 2007:41). This globalizing of definitional frames and resulting relationships between indigenous people across the globe represents one way cyberactivism can serve tribal interests.

46 In one example, at the American Anthropological Association Annual Meeting in 2012, I attended a panel discussion 'Indigenous Peoples' Rights and Natural Resource Extraction in Southeast Asia: An International Live Streaming Discussion" in which a faculty member of Australian National University made this case against small-scale miners on behalf of his employers, resource extraction corporations in Indonesia. 
As Adam Lucas (1996) suggests, new media technologies offer solutions to communication between native peoples spread across the vast continents of North America and Australia. He proposes that this kind of communication networking makes it easier for native peoples to "compare and contrast their respective social, cultural and political situations" (Lucas 1996:104). Indigenous cyberactivists also face internal critiques of activism online. Those who see a conflict between technology and "universal" indigenous values challenge the authenticity of indigenous voice online. In one such critique, Howe has described the Internet as "antithetical to the particular localities, societies, moralities and experiences that constitute tribalism" (1998:27). However, as Lucas argues, "new computing and telecommunications technologies offer exciting possibilities for indigenous people to preserve and develop their own cultures on their own terms" (Lucas 1996:103). Regarding the recording of oral traditions, he writes:

The problem is not therefore one of recording knowledge that was not meant to be recorded, but of the custodians of oral lore being given the opportunity to develop protocols, customs and conventions for recording and disseminating oral knowledge in a way that is consistent with local traditions and community desires. [Lucas 1996:103]

Critiques positioning tribalism or indigenous identity in opposition to new communication technology may be underestimating both. In my fieldwork with indigenous activists and the Occupy movement, I found people in West Papua organizing online, and partnering early with the emerging Occupy movement. They not only engaged in collaboration with civil society organizations such as the East Timor and Indonesia Action Network (ETAN), but also through dozens of West Papuan created and controlled Facebook pages for Papuan activists, media outreach groups, as well as political prisoners. 


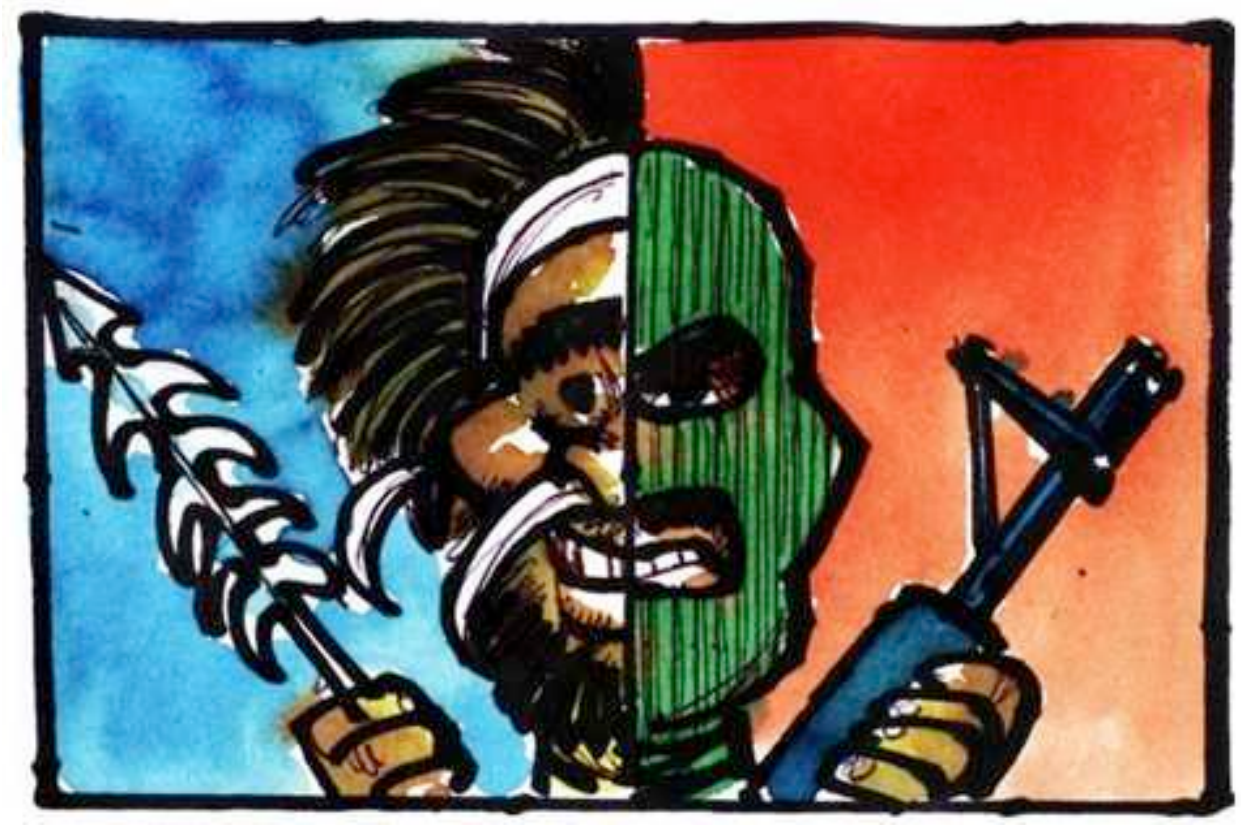

Figure 16: "Savages or Terrorists?"

These engagements online also serve as a means of regaining control over how indigenous activists are imagined. As West Papuan activists share their own images and perspectives for a potentially global audience they work against stereotypes, such as those depicted in this political cartoon (Figure 16). The image reflects the binary perception and depiction of West in Indonesia: are they "tribes of noble savages"? or "guerrilla fighters" and "terrorists"? Whether portrayed as "uncontacted tribes" who might still be cannibals, or depicted as militarized guerrilla fighters - the stereotype of the people of West Papua as violent and dangerous is used to continue colonial oppression under Indonesia's neocolonial occupation. 


\section{CONCLUSION}

In the West, we want answers for everything. Everything is right or wrong, good or bad. In the Wayang no such final conclusion exists.

-Billy Kwan ${ }^{47}$

This ethnography has followed global connections and along the way found sites of connection and disconnection. The more I looked into the online Indonesian activist community the more questions I came away with. As an activist project, it must also remain somewhat unfinished, it must be part of a process; ongoing and productive. At the same time in order to be shared, it must be declared finished; labeled concluded.

As I finish writing, Oxford Dictionaries has declared "selfie" the word of the year; Facebook use among youth is declining in favor of Instagram, Twitter, and chat applications; and while the Indonesian Governor of West Papua declares the area is open, foreign journalists are still unable to get permission to enter and report from the region. Occupy is a memory for some, but an ongoing and productive idea for other activists through projects like Occupy Sandy hurricane recovery in New York; Strike Debt; the Idle No More indigenous movement in Canada; and the vibrant community in Indonesian Occupy Facebook groups where a new group of young activists are continuing the conversations started by older generation activists like $\mathrm{Bu}$ Citra.

I have written here about my first visit to Occupy Wall Street in lower Manhattan; about my search for the globalizing movement online; and about an Indonesian ex-pat discovering Occupy Seattle the day before I found the emerging Indonesian Occupy movement. Through my participation in the U.S. and Indonesian Occupy movements, this research followed connections

${ }^{47}$ The Year of Living Dangerously, Weir (1982) 
to Jakarta, and to a mine in West Papua which led me back to Wall Street as I traced the flows of capital and power through a shared and contentious Indonesian-U.S. history.

I have tried to follow these stories across space and time. This has also lead to an investigation of how the Internet and the ethics of the hackers who built it have shared origins in the U.S. anti-war and counterculture movements of the 1950s and 1960s (see Appendix C) at the same time a horrific massacre was occurring on the other side of the world in Indonesia. Both of these histories are still being erased as whistleblowers today write a new history of the Internet in terms of the end of privacy and while a European filmmaker is encouraging Indonesians to discuss the 1965 massacres with little effect.

Justice remains elusive for Indonesians, in part because International Justice mechanisms are limited by their foundations in European power, and also because international efforts are blocked by powerful nations with vested interests in maintaining political and economic control of Indonesia. Almost 70 years after officially gaining independence from hundreds of years of colonial and imperial domination, the Indonesian state has itself become a colonial power in West Papua, and built intimate relationships with the world's super powers, all while continuing to avoid international accountability for atrocities. Justice is denied for the victims of the 1965 massacre, for the victims of genocide in Timor and Papua, for the ethnic Chinese persecuted in 1965 and again in 1998 and for religious, sexual, intellectual, and cultural minorities across Indonesia.

In all of this injustice however, I found a community of online activists who still imagine the possibility of a different, perhaps even more just world. I found individuals and groups rewriting what it means to engage in political action in the globalizing world, and in the spaces of the Internet. So I close with the suggestion that we listen to them. 
When the online engagements of actors in the globalizing Occupy movement are ignored, dismissed, or assumed to be identical to that of the U.S. Occupy movement, the textured terrain and localism of the transnational social movement is leveled. The privileging of the physical as what "really matters" acts to erase the subaltern and indigenous voices of those who engage in the Occupy movement online in political, legal, and social environments where the stakes of physical occupation are high.

Privileging the physical also erases the voices of those activists whose lives are in some part constituted online and who are therefore necessarily engaging with memory, identity, and culture in those online spaces. Privileging the physical also risks missing the irregularities, and unexpected forms of knowledge production occurring online, such as new meanings of the word occupy; the reconsidered histories and biographies of movements and activists; and the emergence of embodiment and worldness in places like Facebook (see Appendix B), which have not usually been considered virtual worlds.

In anthropology, we are especially well positioned to investigate online activisms and their imaginative universes without neglecting the histories, biographies, inheritances, and political economies of both the technologies and lived experiences implicated in online socialities. To better hear and understand emerging movements, all of their occupations, creativities and practices (whether in physical squares or cyberspatial ones) need to be taken seriously and understood as part of the field of what "really matters." 


\section{APPENDIXES}

\section{A. Notes on Methods and Analysis}

C.J. Pascoe appends her ethnography of masculinity and femininity in an American high school with an appendix titled "What If a Guy Hits on You? Intersections of Gender, Sexuality, and Age in Fieldwork with Adolescents" (2011:175). While Pascoe includes a methods section in her chapters, something I've chosen not to do, it was while reading the appendix that I thought 'oh, this is what she did!' and felt as though I had understood something about her methods I could not get from the rest of the book. Inspired by Pascoe's appendix, I aim to do two things in this section: first, I want to describe in more detail the methods I used during my fieldwork; second, to clear up any 'black box' around my analysis by reflecting on that process. I approach these two tasks at once because the data collection and analysis were an inseparable process in this project. I am including this appendix because when I looked for examples of online methods used by MA candidates in my anthropology program I found none, and even in the published literature there is little in regards to ethnography of Facebook and almost no literature on Facebook and social movements from an engaged perspective.

As I describe earlier, I was working at the Occupy Wall Street Library (The People's Library) when I first discovered an emerging Indonesian Occupy movement online. As soon as I found the first hints of this online movement in October 2011, I began collecting data and organizing it. This early data took many forms including: screenshots of web sites, Meetup groups, Facebook pages and posts; word processing documents where I recorded notes and text; images downloaded from web sites; references for newspaper and blog articles; maps of Indonesia and social networking sites; links to web sites, and more. In this early stage, I was 
working without any research plan or purpose beyond my own curiosity, and so I collected anything and everything I came across.

This early data was organized into a series of nested folders on my computer. I created a folder for each new Facebook group; within that folder I kept screenshots and PDFs of that group's activities. I began creating folders for informants full of images from their Facebook profiles as well as a text document describing when and how I had first found the informant, along with copies of all correspondence with them. I created folders for news, for physical occupations, for material about Southeast Asia, for data about West Papua. These folders came to take up about 200 megabytes of data. To visualize that in physical space, 'Internet wisdom' suggests 200 megabytes is about equivalent to two yards of books on a shelf.

To discover new data I performed Internet searches using Google.com, joined Facebook groups, searched for new groups on Facebook, and posted links to a short survey on Occupy Facebook groups. I created my first survey in order to get in touch with English-speaking informants (as this was prior to my study of Indonesian), and I included a question at the end of the survey through which informants could share contact information if they wanted to talk further. The survey questions were:

\section{How did you first hear about the global Occupy Movement?} (open ended response)

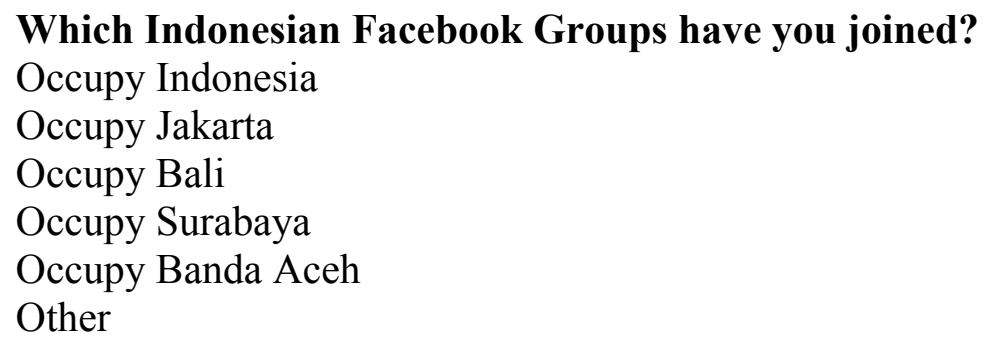


Have you gone to an occupation meeting in person?

Yes

No

I plan to

Other

How would you describe your political views or beliefs?

(open ended response)

How did you first participate in the Occupy movement?

Online

In-Person

What made you decide to join an Occupy group on facebook?

(open ended response)

Do you think of Facebook as:

Public Space

Private Space

Public \& Private Space

Other

How did you first hear about the Occupy Indonesia groups on Facebook?

(open ended response)

If you would like to talk more about Occupy Indonesia and share more thoughts, I would love to hear from you, enter your email and I'll contact you, thanks!

(open ended response)

Posting this survey inspired several informants to contact me and we had fruitful conversations through Facebook messages, email and conversations on the timeline/wall of Facebook groups.

In November 2011, I wrote to Tom Boellstorff for advice on methods to conduct ethnographic research in cyberspace. I wrote:

Forwarded message ----------

From: Michael Oman-Reagan

Date: Thu, Nov 3, 2011 at 2:36 PM

Subject: Indonesia, Cyberspace, and Ethnographic Methods

To: Tom Boellstorff 
$[\ldots]$

I have an online life of my own, but find myself running up against a bit of uncertainty when looking for methods for doing ethnographic fieldwork on Facebook. I wonder if you have a syllabus for a course on methods or any books/articles that you would recommend.

I suppose I'm asking if, when thinking about methods in cyberspace, there was anything in particular that gave you an "ah-ha" moment? I'm collecting 'data' but there's so much of it!

$[\ldots]$

And Boellstorff replied:

--------- Forwarded message ----------

From: Tom Boellstorff

Date: Thu, Nov 3, 2011 at 5:27 PM

Subject: Re: Indonesia, Cyberspace, and Ethnographic Methods

To: Michael Oman-Reagan

$[\ldots]$

Look at Daniel Miller's Tales from Facebook in terms of the Facebook methods stuff. In terms of "a-ha" moments and all that kind of stuff, look at the methods chapter (ch 3) of my book Coming of Age in Second Life. I am right now finishing a new book with 3 colleagues, "Ethnography and Virtual Worlds: a Handbook of Method" - that will be interesting for you I think, though sadly it won't be out until next July or so! Take care - All the best, Tom Boellstorff

I read Boellstorff's methods chapter (2008) and also Daniel Miller's Tales from Facebook (2011) as I began going online and engaging in participant-observation. As I continued developing my methods for this project over a several month period beginning in 2011, Boellstorff et. al.'s (2012) handbook of methods for the ethnography of virtual worlds was not yet published.

After I had developed my methods and had been using them for about one year I was able to read Boellstorff et. al. (2012) and found that my choices matched many of those suggested by the four authors of that volume. Although their collective experience in online work makes that volume a great introduction for those engaging in online fieldwork for the first time, I felt that much of it was rather obvious based on my experience as an 'online native' as well as my 
training in anthropology. Their chapters on ethics and institutional review boards may be especially helpful to those facing review in institutions unfamiliar with online work.

My own experience with the institutional review board was an example of the challenges faced by both researchers and review boards as researchers increasingly do online fieldwork. Review boards seem to have enough of a challenge with open-ended ethnographic methods like participant-observation, and in my case they seemed even more confused when those methods were extended to the online environment. My first application was approved after several revisions, and later my application to continue my research was not approved again but rather exempted from review. I can only assume this confusing outcome meant that in the time between my original application and my application to continue my research, the review board had reconsidered their position on certain types of online research.

In my personal online life, I have 20 years of experience engaging with online communities in IRC, Friendster, Myspace, Second Life, Facebook, Twitter and others. I began this project as a regular heavy user of Facebook. I had also been regularly using Facebook to engage in my work with Occupy Wall Street. To collect data on the Indonesian Occupy movement, I began with the same techniques that I used in my personal online life: I joined Facebook groups, posted links, questions, and comments. I started conversations that sometimes led to friend requests, and later to Facebook friendships with informants. In some cases, I began e-mail exchanges with informants who had long stories they wanted to share that were better suited for the letter-like format of e-mail.

My Indonesian Facebook friends were incorporated into my personal Facebook life. I did not use a new specially created account to engage with them. This was a decision based on two ideas. First, I believed that if I was going to ask them to talk to me about issues that were 
contentious in Indonesia and share personal information, I ought to be willing to do the same. Second, I felt that if my informants 'stalked' my Facebook profile and saw my long history of engaging in online activism, saw the mutual friends and groups, and my activity on Occupy Facebook groups, they would be more likely to trust me. The legitimacy of my Facebook account helped to establish my credibility with my informants as an activist.

In my conversations with informants, I told them about my experiences with OWS in New York and my work with the People's Library while at the same time I asked about their experiences. I explained that I was both an activist and a student, and that I was working on research for a paper I was writing. Early on, I chose to reach out to Indonesian activists in English, and for the most part only engaged with informants in English. In the beginning of my research during my primary data collecting phase this was because I did not speak Indonesian. I now have an intermediate high proficiency in Bahasa Indonesia and have used Indonesian language to discuss activism with some informants since returning from Indonesia.

I also provided informants with my full legal name, which is not the name I use for my personal Facebook account although I also maintain a professional Facebook account under that name. To protect the identities of my informants I turned to baby naming web sites where I could choose an Indonesian name from a list. I used these pseudonyms in all of my writing about the informants that others might read and edited the field notes included in this work to use the pseudonyms. In some cases, my informant's 'true' identity was unknown to me. In Facebook pages, as opposed to groups, a page administrator can post updates, links, and comments using the identity of the group so that the author of the text appears to be the group. Pages may have any number of administrators, so that multiple users may be writing from the same identity with different voices while they all appear to be coming from one user. This activity reflected the 
same situation for OWS in the United States and so I was familiar with it and with the potential for confusion, complexity, and creativity.

Another possible source of complexity came from the terminology used by the Facebook corporation in their software. When I began my research a "group" on Facebook was structured much like a "page" whereby users could "like" the group and the group administrators could speak with a unified voice from the group account. Part way through my research, Facebook changed groups to become spaces where individual's voices were maintained in the conversation, and where only members of the group could participate. Pages remained the same. In addition, when I began my research a user's profile page feed was called a "wall" and users could "post" to this "wall." This language has been replaced with "timeline," and the structure has changed so that the individual user has, at minimum, two feeds; they can look at their own "timeline" as well as an aggregated feed of all their friends' activity. The "posts" are now generally referred to by Facebook as "status updates" although users still often call them posts. A history of these changing terms and landscapes of Facebook would by itself make a rich research topic.

As I began to get a sense of the kind of searches and online investigation that were turning up useful data, I decided on an early protocol for data collection which I described in an early note titled "Methods MASTER":

Facebook Occupy Group Discovery

1. Search Facebook for: Occupy, Indonesia, Duduki

2. Add new groups to the Master List

Facebook Occupy Group Data Collection

1. Create folders for any new groups/pages.

2. Visit the Occupy Facebook Pages on the Master List

3. Scroll down until it stops, print a PDF, add the date to the name.

4. Add Group to Master List 
News \& Media Discovery

1. Search online for: Occupy, Indonesia

2. Print and sort articles by appropriate folder

Informant Discovery

1. Check Survey at QuestionPro for new respondents

2. Add respondents to Master List

3. Fill in fields

4. Create folder for new respondents

5. Create file document for respondents

6. Add PDFs of Facebook profile or other social media profiles

While my folders of data were well organized, they were increasing in number and content daily. I felt as though the data was becoming locked up in the nesting of the folders, which was increasing as the Indonesian Occupy activity increased. I was frustrated that I could not see the data more easily and play with it in the way I wanted to. To understand what I had been collecting and what it meant, I needed to have more control over both searching through and seeing the data. I also wanted to be able to add tags and search those tags. To solve these problems, I began using Evernote. ${ }^{48}$

Evernote is a free software and online service for note taking. The software plugs-in to web browsers to allow "web clipping" a feature that extracts and reproduces web pages in a note which can be preserved for future use. It allows the creation of multiple notebooks and nested notebooks, as well as tagging, searching, and visualization. I found Evernote to be a better solution than software specially designed for qualitative analysis for a few reasons including: it can be installed on multiple operating systems and devices, it synchronizes across those operating systems and devices silently and instantly, and it is free. In my previous work as a technology specialist at the CUNY Graduate Center I had frequently suggested Evernote to anthropology faculty who were collecting qualitative data as a cloud based replacement for

\footnotetext{
48 evernote.com
} 
Filemaker and other database programs. In one case, I worked with Fernando Coronil to teach him how to move his field notes into Evernote. His untimely death brought that project to a close, but I am grateful for the chance to have worked with him and for what I learned about the challenges of digitizing and migrating field notes and images from other systems into cloud based software like Evernote. Despite recommending it frequently, I had avoided using Evernote myself prior to this project.

When I began using Evernote, my first step was to transfer all of my data from the nested folders into the software. I did this by copying notes, text, images and other forms of data into new notes. I replicated the structure of the folders I had been working with in the structure of the new notebooks in Evernote (including nested notebooks in some cases). I also transferred a word processor document in which I had been taking all of my field notes and copied them into a new notebook, with a separate note for each date. This processes of migrating my notes and data from one format to another was also an opportunity to re-familiarize myself with the data I had collected, to sift through it, to let older data come into contact with newer data and to re-read my field notes from the beginning.

Drawing on these data and field notes I wrote 15 papers on the topic of activism in Indonesia from Fall 2011 to Fall 2013. Each paper was an opportunity to work through particular questions and ideas that emerged from the ongoing fieldwork. The papers included: "Bantar Gebang: An Urban-Refuse Waste Picker Community at Indonesia's Largest Landfill" - "Islam and the Right to Expression: The Case of Alexander Aan" - "Occupying Papua: Indonesian Cyberactivism, Sacred Terrain and \#OccupyWallStreet" -

“Archipelagic 'Unity in Diversity': Pancasila, Religion, and Human Rights in Indonesia” “Images and Metaphors of Occupy: One Year On” - “'O Hele Ho' and the Imperial Cartography 
of "The Journey of Sounds" - "Archipelagic Nationalism and Chinese Culture in New Order Indonesia" - "The Indonesian Occupy Movement: Reformasi and Cyberactivism in the Ruins of Empire" and "Bali in Manhattan, Hinduism on the Jersey Shore and Lady Gaga vs. Islam: Gamelan Dharma Swara at Le Poisson Rouge.”

In addition to the papers, I published a paper on my research in the journal Critical Quarterly (Oman-Reagan 2012), wrote several grant proposals using the fieldwork data, and gave three conference presentations (The "How Class Works" conference at Stonybrook University; A departmental presentation at Universitas Negeri Malang, in East Java Indonesia; and a presentation at AAA 2013 mentioned below). I also wrote a paper in 2007 on cyberactivism which I revisited and incorporated into my fieldwork and my ongoing writing. Writing these papers, grant proposals, and giving presentations allowed me to repeatedly engage the historical research and theoretical analysis with my participant-observation data and feedback from professors and peers.

The first draft of this text was produced by merging these 20 or so documents into one word processor file to create the backbone of this ethnography; a starting point for this final document. After merging the documents, I waded through the text to remove repetition and organize the writing into sections derived from those texts. The structure of this ethnography emerged as a dialogue between the documents I had produced over the course of the fieldwork and several lists of potential chapter titles my advisor, Yukiko Koga, requested that I send to her in e-mail correspondence.

Once I had merged the documents together and decided on chapter and sub-section divisions, I began going through my field notes and data and pulling out relevant information to add to the existing text. I did this methodically, beginning from the earliest notes and 
incorporating them as I moved toward the more recent, all the while checking my reflections against the notebooks full of data I collected from 16 Indonesian Occupy Facebook groups and their members over the course of two years. While doing this, I have also been writing two new papers which have been contributing new perspectives to this work: "Justice for '65: A Massacre Forgotten, A History Erased" and "Structural Techniques for Resistance in Documentary Filmmaking: Unmaking Hegemony Through Reflexivity and Participation.“ As I wrote these papers, some of the text produced in them has been incorporated into this ethnography.

These processes of analyzing my data were also influenced by participation in two seminars: "Law and Anthropology" with Yukiko Koga at Hunter College, CUNY; and "Transnational Social Movements" with Marc Edelman at The Graduate Center, CUNY. In both of these seminars vigorous class discussions, paper draft review, and presentations allowed me to test my ideas and get important critiques and feedback.

Finally, in late November 2013 I presented my research at the American Anthropological Association annual meeting in Chicago as part of the panel "Bridging Digital and Physical Publics: Digital Anthropologists' Current Engagements With 21st Century Publics.” In preparing for that session, I had the opportunity to refine some of my arguments especially around offline actions oriented toward online spaces. The extended discussion session in our panel, and the excellent questions and comments from the attendees were also incorporated into this final version of the text.

After the above processes, I still take this document to represent potential rather than finished product. It is my intention to continue the processes of writing, revising, presenting, and to develop each of the topics and sections in this ethnography into three or four papers for 
publication. My methods and my analysis are ongoing, as is the work of writing on and learning about the world.

When I sought out previous theses by students in the Department of Anthropology at Hunter College in course of this project I found several of interest and wanted to reach out to their authors to ask questions. However, I could not find their author's contact information. So I close with the following: If you should happen to be a student or scholar who has found this volume and you would like to correspond, please email me: omanreagan@gmail.com. 


\section{B. Theorizing an Anthropology of Cyberspace}

One day, a trader on the floor of the New York Stock Exchange, Adam Sarzen, a decade or so older than many of the protesters, came to Zuccotti Park seemingly just to shake his head. "Look at these kids, sitting here with their Apple computers," he said. "Apple, one of the biggest monopolies in the world. It trades at \$400 a share. Do they even know that?"

- New York Times ${ }^{49}$

\section{Clicktivism and Self-Immolation}

My work with online activists challenges popular discourses around "clicktivism" a term originally coined to distinguish between online activists who adopt the "logic of the marketplace" and those who reject it. ${ }^{50}$ In light of the complex biographies, histories, and practices of the activists I worked with, I am surprised how often anthropologists still question the legitimacy of studying social movement's online actions as meaningful data.

In part, they do so because the simplification of the "clicktivism" discourse often does precisely what the term was meant to work against: replace complex online lives with userinterface data acts such as "clicks." Instead, when looking at social movements online, I propose turning the ethnographic focus toward the cultural activity those data acts constitute when they are understood as part of a complex, emergent, socially and historically situated engagement in cyberspace. In terms of methods, therefore, I suggest that simply because one can reduce online activity to clicks and bytes for analysis doesn't mean this is always the best way to engage in the anthropology of cyberspace. While Big Data analysis and quantitative approaches to studying online action may suggest areas for further inquiry, these approaches may also mask the unexpected and the irregular in the textured terrains of activism and social life online.

49 September 23, 2011 (Bellafante 2011)

50 For the origins of "clicktivism" see: http://micahmwhite.com/clicktivism-articles/ 
Online social movement activity can also be uncertain in its effectiveness yet still provide insights. It does not need to be homogenized into either a new utopian era of democratized information on the one hand (as some accounts of Occupy do), or the pejorative clicktivism or slacktivism with their connotations of political impotence, laziness and capitulation to a globalizing capitalism.

Instead anthropologists working online can look at engagements in cyberspace with the same techniques used to analyze other practices and those systems of meaning Geertz called imaginative universes. Whether looking at Indonesian shadow puppets in East Java, an Occupy Library meeting conducted on Skype, or images posted in an Indonesian Occupy Facebook group, engagements with technology all have place specific emergent cultural properties that can be understood as more than the sum of individual data acts. ${ }^{51}$

A team of sociologists at UNC-Chapel Hill (Caren and Gaby 2011) looking at the U.S. Occupy movement on Facebook concluded the social media site was used primarily for "recruitment of people and resources to local occupations" and that "the focus of Occupy Wall Street is on mobilizing individuals offline." They also concluded "online activities greatly facilitate these efforts." Despite the creation of more than 400 unique pages and over one million posts and comments on U.S. Occupy movement Facebook groups, online activity is often interpreted this way; as little more than media serving to facilitate the "real" movement, which is perceived to be taking place in physical space.

The first and still most active OWS Facebook page ${ }^{52}$ was created as an "event," rather than a "page" or a "group." Many of the OWS pages created later by supporters or affinity groups on Facebook were also created as a page rather than a group. Groups (as opposed to

51 I first encountered the idea of all technology as techno-cultural hybrids in Davis (2004). More recently it has been framed in terms of ethnographic methods by Boellstorff (2008) and Boellstorff, et. al. (2012).

52 www.facebook.com/events/144937025580428/ 
pages or events) on Facebook afford members greater opportunities to engage in participatory decision making and extensive discussion, whereas pages and events are more hierarchical by design and serve better as tools for more unidirectional broadcast of information from an organization or group of administrators to supporters. In contrast to much of the U.S. Occupy movement's use of Facebook, the most active Indonesian Occupy Facebook sites are groups. Rather than being primarily a forum for announcements and organization of offline activities, Indonesian occupiers use these groups for substantive conversations and platform building.

\section{Occupying Cyberspace}

In Tom Boellstorff's ethnography of Second Life, he chose to study the virtual world of Second Life on its own terms, to take the activities of the inhabitants and users as "legitimate data about culture in a virtual world" (Boellstorff 2008:61). Boellstorff conducted his research entirely within Second Life, making no attempts to visit Linden Lab, the corporation that created and maintains the servers and software on which the virtual world runs, nor any effort to meet Second Life residents in the physical world. I agree with his articulation that demanding ethnographers of virtual worlds always meet their informants in the physical world for context "presumes that virtual worlds are not themselves contexts" (Boellstorff 2008:61).

I take Facebook to be not only a social networking site, but also a virtual world. Facebook users engage in several actions that suggest they are engaging as though Facebook were a virtual world: the production of profile photos (like avatars); augmented profile names such as the middle name "Hussein" during Barack Obama's 2008 presidential campaign, or the middle name "Equality" during the Marriage Equality movement; entirely pseudonymous screen names despite Facebook's attempt to stop this practice; and explicit constructions of more than one distinct online identity. Additionally users on Facebook create pages and groups for their 
workplaces, their organizations, and their life-events. They chat, navigate between cyberspatial territories, and engage in the full range of activities available to users of Second Life or other virtual worlds.

In considering Facebook as a "virtual world" I diverge from Boellstorf et al.'s Ethnography and Virtual Worlds: A Handbook of Method in which the authors note they "do not consider social networks like Facebook [...] in and of themselves to be virtual worlds in our definition" (2012:7). I first read Boellstorff et. al.'s newly published handbook of method (2012) after over one year of fieldwork with the Indonesian Occupy movement and discovered that I had been engaging in the same methods my colleagues suggested as best suited to the study of virtual worlds. In part this is because, as the authors also recognized, the methods of ethnography are easily applied to online environments. In fact, despite disagreeing with their conclusion, I find Boellstorff et. al.'s definition of virtual worlds fits my understanding of Facebook quite well. They define virtual worlds as: places with a sense of worldness, including objects and environments that you can traverse and interact with; places which are multi-user in nature, containing shared social environments with synchronous communication and interaction; places which are persistent, in that they continue to exist when users log off; and which allow participants to embody themselves, usually as avatars (2012:7). Boellstorff et. al. do not consider Facebook a virtual world because of its "lack of worldness and embodiment" (2012:7). However, I take issue with this approach and framing because it relies on the perceived structure of the software on Facebook rather than the activity of users.

While Facebook may not have originally been designed as a virtual world like Second Life, Facebook is being used as such by participants. I recognize the practices I see may also be related to localized forms of Facebook use, as discussed in Miller (2011). I wonder, however, if 
the virtual-ness of an online space might be better examined by looking at how an online space is used rather than only the structure of the software or user-interface. Instead of focusing only on the architecture of the space, or the perceived physicality of that interface, perhaps a better approach can refocus the assessment to look at the social structures emerging in dialogue with that structure (as well as user's location specific practices) to measure virtual world-ness.

In his ethnography of Second Life Boellstorff defines a virtual world as "places of human culture realized by computer programs through the Internet" (2008:17). I propose a reversal of this definition so that it is participant focused to become: networked computer programs running on the Internet where humans realize their cultures. My approach of focusing on user and participant activity opens virtual worlds to multiple, simultaneous, and sometimes contradictory uses. Some users may participate in Facebook as a virtual world by constructing identities and navigating the landscape in an interactive way that realizes culture within the software. Others may not, and may use it more like traditional media for the unidirectional broadcast of information. This brings my analysis of Facebook more in line with understandings of physical space where spaces can be re-purposed - a public square may be occupied, enjoyed, or used as a space of commerce. Instead of the space dominating, the users also bring the meaning to the space in dialogue with the physical structures.

Notes on my own online history and use:

When I first began using Second Life, I thought of its virtual world as a very different place from social networks like Friendster, MySpace, and later Facebook and Twitter. However over several years of use and especially while doing this fieldwork, I began to see myself and my informants using both places in similar ways. For example, I have relationships that are only on Facebook, friends there with whom I interact almost everyday but have not physically seen in years. I also have persistent Facebook friendships that have developed after meeting a person only once, and then never again in the physical world. 
As Boellstorff et. al. point out conducting participant-observation in virtual worlds requires participation in virtual world activities, entailing "intense involvement and engagement, often to the point of mastery" (2012:2). I have been engaged in online environments since my first year of undergraduate education in 1994, which was also the first year of the World Wide Web. I was first active in IRC, and Bulletin Boards, later in Second Life, and now in Facebook among others. The first web site I built in 1994 was built as a navigable spatial environment that I called "The Space." Clicking on navigation spheres brought the visitor to different rooms of the site. From my first online engagements I saw the Internet as a virtual world with spatial components and the user as embodied within those spaces.

In my own Internet use, I have taken approaches from one online space and carried them into another, and I wonder if others may be doing the same. For example, I have two Facebook accounts to use for different purposes, just as many users do in Second Life. The use of Facebook accounts under pseudonyms mirrors the Second Life practice of creating "alts," alternative avatars for navigating the virtual world without being recognized except by those in on the secret. ${ }^{53}$ This technique is also becoming more popular as online surveillance increases and users seek ways to continue using online identities without compromising their privacy.

Previous approaches to studying virtual worlds use theoretical and methodological foundations from game studies, but Boellstorff argues that these approaches rely on the notion of culture as a system of rules which, following Geertz, he sees as confusing a "derived representation with lived social experience" (Boellstorff 2008:68). In contrast to a rules-based approach and “elicitation methods" such as surveys and questionnaires, Boellstorff proposes using participantobservation (Boellstorff 2008:68). This is the approach I have taken in my work online.

Participant-observation, for Boellstorff, offers no illusions of objectivity, because it constantly confronts the differing forms of power and hierarchy produced through fieldwork. He suggests using participant-observation, not to look for the extraordinary in the virtual world, but to look at the mundane, to "find social meanings as they are implicitly forged and sustained in everyday interaction" (Boellstorff 2008:75). This ethnography is written based on two years of situated engagement in the field, and I use key cases, incidents, quotes, and informant stories to

53 Boellstorff discusses alts in Second Life as well (2008:132). 
illustrate patterns and synthesize what I have learned from my fieldwork. As Boellstorff et. al. point out, these examples should not be taken as anecdotal, but rather as a means of setting the stage for analysis, discussions, and posing questions (2012:40).

It is in the everyday interactions on Facebook that I found the Indonesian Occupy community of practice. As Daniel Miller concluded during his research on Trinidadian Facebook use, localized forms of Facebook quickly develop their own "genre and expectations" which set them apart from others (Miller 2011:158). By examining localized Facebook use within the Indonesian Occupy community of practice, I began to see the local manifestation of Facebook use by Indonesian cyberactivists.

\section{Facebook as Virtual World}

The localized forms of Facebook (perhaps more accurately described as the localized social practices of Indonesian Occupy movement users on Facebook) point to the emergence of the two characteristics that Boellstorff et. al. argue characterize a space as a virtual world: "worldness and embodiment" (Boellstorff et. al. 2012:7). Facebook has not previously been understood as a virtual world, however my experiences with the Indonesian Occupy movement suggests that Facebook is being used as a virtual world by at least some users.

Online virtual worlds with embodiment and worldness have been defined in contrast to text based online virtual worlds, (such as IRC, MOOs and MUDs) which have been framed as "places that are not spaces" (Boellstorff 2008:67). In virtual worlds that attempt to replicate or recreate the sensory experiences of physical space (such as Second Life and World of Warcraft) users embodiments in those spaces are often called avatars. In Facebook the role of the avatar is played by a user's profile, or in some cases a group's profile. The experience of embodiment in Second Life is enacted through the construction of the avatar, and then through interactions with 
other users avatars in a simulation of three-dimensional space. But in my fieldwork, I found users on Facebook also building their profiles as avatars, and navigating space by moving between their "home" profile and that of groups or pages. In doing so, they differentiate what and how they post in these different spaces.

Recent changes to Facebook moved the structure of the Facebook experience further toward an embodied environment. The oldest point on a users wall (now called a timeline), is the point of the user's birth. From this point forward, the user's timeline traces the digital life history of the profile until the present day. Boellstorff notes it is not only in virtual worlds that embodiment is negotiated - in the physical world we are also embodied in "a social and cultural sense" (2008:135). This social and cultural embodiment is not simply echoed on Facebook, it is constructed and produced in the interaction between users and the software. Just as they do in online worlds like Second life Facebook creatively play with their profiles to construct multiple and changing identities.

User practices of posting "selfies" on Facebook timelines, updating profile content, "checking in" to locations, and discourses around profile images are all embodied practices through which users test, change, and share their online and offline identities. These online identities, and the meaning produced around them in turn affect embodiment in the physical world. Like the Indonesian Occupiers photographing the protester holding a sign of a protester holding a sign, users today regularly perform physical world actions intended to produce online moments.

In contrast to cyborg embodiment, Boellstorff writes that "virtual embodiment is predicated on a discontinuity, the gap between virtual and actual" (2008:138). Within this gap, between the physical world and the anonymous online world, in the "nonymous [non- 
anonymous] online world [...] emerges as a third type of environment where people may tend to express what has been called the "hoped-for possible selves"” (Zhao et. al. 2008:1819).

In fully embodied virtual worlds like Second Life the user's hoped-for possible self might have wings, be a different species, and be able to teleport. In Facebook, however, the hoped-for self is displayed through editing out unflattering photos, presenting images of the user in distant or exoticized locales, with certain groups of people or in places that have particular significance. These choices and the ability to craft the Facebook profile can help to erase the parts of physical life that the user would not like to bring into their online identity, as Zhao et. al. note:

While explicit identity statements often take the form of autobiographic descriptions given by the users, implicit identity statements can be found in the impressions 'given off' by the users. For example, by selectively listing one's affiliations with certain groups, activities, or hobbies, an individual is implicitly making an identity statement about him or herself. Those online identity production strategies enable people to stage a public display of their hoped-for possible selves that were unknown to others offline. [Zhao et. al. 2008:1820]

In addition to the active projection of the hoped-for self, Zhao et. al. note that users may engage in the opposite action as well - projecting an image online that they hope they can also carry into their offline life:

Facebook users may emphasize or even exaggerate the part of their possible selves that are socially desirable but not readily discernible in brief offline encounters, such as one's character, intelligence, and other important inner qualities. At the same time, they may seek to hide or de-emphasize the part of their selves they regard as socially undesirable, such as shyness, overweight, or stuttering. [Zhao et. al. 2008:1821]

Zhao et. al.'s study also found that users may go further, producing identities that cannot be established in the offline life, bringing Facebook identity creation in line with avatar creation in more embodied online virtual worlds: 
Our findings suggest that Facebook enables the users to present themselves in ways that can reasonably bypass physical "gating obstacles" and create the hoped-for possible selves they are unable to establish in the off-line world. [Zhao et. al. 2008:1831]

Worldness is a more challenging concept to address in Facebook. The first issue I encountered is that the word "worldness" only appears once in Boellstorff et. al. (2012), and so I can not be certain what it means for these authors. However, users have a choice over who sees which posts and what aspects of their profiles - just as they do with their private space in the physical world. Additionally, users post about physical activities, and check-in via status updates that explain what users are doing 'right now.' Users profiles become linked with other profiles through check-ins at locations along with other Facebook users. Each of these suggests qualities that are like the experience of "the world." I wonder, if Alexander Aan can be sentenced to 2.5 years in prison for what he posts on Facebook, doesn't that also speak to the worldness of it? Action on Facebook can be seen as meaningful actions in the real world.

In a study of EverQuest, Klastrup argues that the games "worldness" is a unique characteristic of an online gameworld which emerges:

in the complex interplay between a) the aesthetics of the gameworld as both an actualised explorable and mentally imagined universe; b) the experiences and means of expression the world as a game system and tool allows and affords; c) the social interaction in and about the world. [Klastrup 2009]

Klastrup begins to build the term worldness out of discourse which attempts to define the "literariness" of literature, arguing:

We can speak of worldness on a very abstract level as a number of essential aspects applicable to all worlds and on a specific level as the defining characteristics of an individual world, reflected in the way the general properties are set into motion and transformed by the world once implemented and by its players. [Klastrup 2009] 
In this sense, worldness is mutually produced by both the users and the environment, emerging at the intersection of the two - and always changing. Klastrup also suggests several characteristics that can be used to explain the worldness of a given world immersion, presence and engagement:

The concept of immersion could then be used to describe the initial creation of and then continuous on-off belief in the world [. . .] The concept of presence could additionally describe the feeling of 'being there' [. . .] Engagement in the world is what emerges through the experience of the world in time, the continuous and combined experience of immersion and presence; the experience of living in the world. This engagement not only relates to the actual experience of playing (in) the world, but also to the mental act of interpreting and connecting the events which take place in it. [Klastrup 2009]

Using these characteristics, Facebook worldness can be further understood as the extent to which users or groups of users are immersed, feel the presence of that immersion, and engage in the online world. In an earlier paper, Klastrup creates the following definition for a virtual world:

A virtual world is a persistent online representation, which contains the possibility of synchronous interaction between users and between user and world within the framework of a space designed as a navigable universe.

"Virtual worlds" are worlds you can move in, through persistent representation(s) of the user, in contrast to the represented worlds of traditional fictions, which are worlds presented as inhabited by real people, but not actually inhabitable. [Klastrup 2003:101]

The idea of "fiction" is an important one here. Hayot and Wesp also hint at fiction when they begin to define worldness in terms of narratives:

a bounded physical space dotted by places, organized by a self-sustaining and seemingly coherent set of historical narratives and physical rules - and an idea of what the world might look like if it didn't look the way it does. [Hayot and Wesp 2009] 
This model is entirely different, and is so specific to virtual worlds with fantasy or science fiction premise that it may not even describe places like Second Life. While in Second Life, users can create such worldness inside the world and often do by creating re-creations of popular fictional worlds such as Blade Runner, or Avatar - Second Life itself has no such history or backstory, none beyond that constructed through the history of engagements by its users.

In referencing "an idea of what the world might look like if it didn't look the way it does," it does describe a persistent character of the U.S., global and Indonesian Occupy movements, a dedication to imagining a world unlike the world today and working toward creating that world. One of the regular slogans of the Occupy movement was "We are unstoppable, another world is possible!" Perhaps, in this sense, the embodiment and virtual (other)worldness I find in Indonesian occupiers use of Facebook groups is a characteristic of use that transcends virtual and physical divides and in so doing, they are demonstrating that to Occupy Facebook is to bring embodiment and worldness into that space. 


\section{A Brief History of Occupy and Online Activism}

One of the chants I frequently heard at OWS marches and rallies is "Wall Street is War Street!" The slogan refers to the perceived web of relationships between Wall Street corporations and the U.S. military. Occupiers see this "military-industrial-complex" as a project of U.S. capitalist imperialism, and as a relentless machine influencing government to make war for profit and to use national military power to protect corporate interests. Not surprisingly, Indonesian occupiers also see relationships between multinational corporations, their government and the U.S. government in similar terms and they distrust reporting by "mainstream" media, believing it to be a mouthpiece for those corporate/government interests.

Field Notes - October 13, 2011 (New York):

Occupy Together Meetup comment on the October 19th Meetup, before the date/location had been set and it was just called "Let's meet in Jakarta Indonesia":

"I will be there in spirit.

Power to the people defending all life on Earth!

Down with Allied Military Industrial (fossil fuel/ nuke) Complex Inc.

Good Luck." -Posted by John October 13 at 5:25 PM

Despite the corporate nature of social media companies, and their goals in amassing advertising revenue and making profit through data mining, social media sites like Facebook also offer an alternative to the mainstream media. Social networking sites do this by facilitating links between those sympathetic with a cause while defying the traditional unidirectional nature of mass media, allowing information to flow in both directions as each participating member multiplies the capacity of the movement to expose local abuses (Kreimer 2001). When activists share 
information through social media, their actions in cyberspace challenge the project of global capitalism (Roy 2004). This mode of activism draws on the traditions of ethical hacking which call for helping those who have been left on the margins of survival (Himanen, et al. 2002).

In the Occupy movement this is, in part, represented by the discourse of the $1 \%$ vs. the 99\%. This discourse works to respond to the perceived transnational web of relationships spun by a "global capitalist elite" by shadowing them with networks of globalizing cyberactivists working on behalf of "the people." Cyberspace thus affords Occupy activists a counterhegemonic means to communicate their intersubjective and subjugated knowledges (Warf and Grimes 1997; Foucault 1980), in other words: a means to engage in activism against existing oppressive power structures by telling their own stories about their experiences on their own terms and amplifying/validating the stories of others which would otherwise be marginalized or erased by those in power. The freedom to communicate without censorship is an essential characteristic of the online spaces where cyberactivists engage. As the Internet continues to move from the founding open-systems approach of its early years to an open-markets approach under globalizing capitalism, cyberactivists fight to retain a public commons in cyberspace and do so by employing discourses of freedom, decentralization, democracy and information liberation (Rosenzweig 1998).

The emergence of OWS online was facilitated by Internet activist groups devoted to Internet freedom like Anonymous; a decentralized, leaderless, horizontal association of hackeractivists (hacktivists). In July 2011 the non-profit Adbusters Media Foundation suggested an "occupation" of Wall Street to protest corporate influence on politics in the United States. This call was picked up online and organized via Facebook events, pages and through other social media. 
Occupier participation in social media sites like Facebook and Twitter serves to bypass the mistrusted information channels of mainstream media and government in favor of crowdsourcing. This is not simply alternative news distribution for occupiers, but is also part of the social movement's practice. Social movements in Indonesia rely on social media to share news about topics generally ignored by the mainstream press and censored by the government such as West Papuan organizing against resource extraction corporations, indigenous people's issues, or the struggles of other highly marginalized groups like atheists, Christians, and LGBT communities. As Pellow (2007) argues, when social movements challenge "official discourses, definitions of the situation, and monopolies on information production" they are engaging in "contentious politics," a kind of disruptive action that Tarrow proposes is necessary for social movement success (Pellow 2007:55). Broader struggles to keep the Internet free and open parallel and often overlap with campaigns to reclaim and occupy physical space in public plazas such as Zuccotti Park and Tahrir Square. In the social movement history lexicon, demands for open access to cyberspace are an online equivalent to the protest chant "the whole world is watching!"

In his 2008 ethnography of anti-corporate-globalization movements Jeffrey Juris describes a "wave of protest against corporate globalization" that "achieved widespread visibility in Seattle" and that can be traced to the Zapatista uprising and their use of online activism (Juris 2008:2). Juris sees cyberactivists within this movement as actors "using the networking tools and logics of contemporary global capitalism to challenge global capitalism itself" (2008:2), however online activism has an anti-capitalist history that can be traced back to the emergence of the early Internet. 
Cyberactivist causes and contemporary online movements can be traced back to 1950 s and 1960s movements such as Students for a Democratic Society (SDS) which in turn have their own historical antecedents in previous generations. I propose that rather than being a new social movement, or simply a reversal of "capitalist logic" onto itself - online activism continues fundamental social justice work from previous generations of movements into emergent newertechnology spaces. Throughout this section I will continue to engage with Juris and others from this position, to explore further aspects of online social justice movements.

Juris also draws on Manuel Castells who regards the "new technological conditions emerging" in our time as "a specific form of social organization in which information generation, processing and transmission become the fundamental sources of productivity and power" (Castells 1996:21). Castells calls the organization of these processes around networks the "network society" and argues that in this new network society individuals experience an "increasing distance between globalization and identity, between the Net and the self" (Castells 1996:22).

In response to the emergence of this network society and increasing alienation, "The Hacker Ethic" calls for actively helping "those who have been left on the margins of survival" (Himanen, et al. 2002:141) and challenges the institutional power of capitalist economic systems:

The radical nature of general hackerism consists of its proposing an alternative spirit for the network society - a spirit that finally questions the dominant Protestant ethic. In this context we find the only sense in which all hackers are really crackers: they are trying to crack the locks of the iron cage. [Himanen, et. al. 2002:12]

This hacker ethic is a "general social challenge" with the explicit goal of "getting everybody to participate in the network and to benefit from it, to feel responsible for longer term consequences 
of the network society, and to directly help those who have been left on the margins of survival" (Himanen, et. al. 2002:129,141).

Building on Castells, Juris proposes that activists do not only use new technologies as tools, but that they use them to practice what he calls "informational utopics," in order to “[physically embody] alternative political visions based on a horizontal network ideal” (Juris 2008:38). This echoes what Calhoun calls "self-exemplification" - the idea that "organizational forms and styles" of movement practices exemplify the values that the movement seeks to put forward (1993:404). Through self-exemplification, Calhoun argues, movements become ends in themselves (1993:404).

I find self-exemplification to be a useful framework for answering the frequently offered critique that Occupy is a movement without clear objectives. The clear and central objective of the Occupy movement is to create a space in civil society where discussion and organization can occur with less interference from existing structures of power relations, and to facilitate processes through which mobilization and consensus become possible around any issues participants choose to bring to the table. In this sense, Occupy is a clear example of Calhoun's self-exemplification because the movement ethics of decentralization and practices of consensus are the ends in themselves.

In a recent article on social media, public space and the Occupy movement, Juris (2012) focuses on two dynamics of online space in the movement: aggregation and networking. He characterizes social media as facilitating aggregation, microbroadcasting, and producing crowds but not serving as well as e-mail listserves for interactive discussions (Juris 2012). While it is true that e-mail lists became the primary means of working group discussions at Occupy Wall Street - Facebook pages and groups as well as Twitter posts were and continue to be rich sites for 
producing and negotiating Occupy discourse; especially in the transnational Occupy movement. Juris also makes several technical errors in his paper, some minor and some larger, which lead me to question his reliability as a source on some aspects of social movement use of technology.

In one example, although he includes the hashtag (\#) and describes its function, he repeatedly writes "\#Occupy Boston" when describing its use online, rather than \#OccupyBoston (without a space), which is the correctly formatted tag. Further, he describes the globalizing of the Occupy movement as "viral" which is not an accurate characterization in light of the wellorganized effort around the Global Day of Action (October 15 $5^{\text {th }}$ 2011). The Global Day of Action was coordinated through Meetup.org and other centrally organized sites and encouraged activists around the world to begin local occupations or have Occupy meetings on that day - and it represents one of the least viral and most structured outreach attempts of the early movement.

There is a tendency in writing about Occupy to either celebrate the social movement's online engagements in idealistic terms that echo Juris's "informational utopics" or to dismiss it as meaningless "clicktivism." The goal of using technology to create non-hierarchical organizational structures and processes that reflect the movement's values is a central part of the Occupy movement, however my experience as an activist and organizer in the movement, as well as my fieldwork with Indonesian occupiers, suggests that these narratives were more often ideals than consistent practices. As often turns out to be the case, the truth is between the extremes.

Describing the Occupy movement as leaderless or horizontally organized and claiming that these characteristics are derived from the technology used by the movement serves to misrepresent both the movement and the technology. Such claims erase the complexity of the movement, the history of hacktivism, and the ongoing processes of online privatization (and 
struggles against that privatization), and the histories and biographies of activists. They also ignore the historical origins of hacktivism and the ethics behind the activism.

Rather than a utopian or technological determinist view of online activism, I am more interested in how, by working online, cyberactivists are engaging with a central and often ignored tool in the struggle for social justice - imagination. While widely known as a theorist of education and psychology, John Dewey was also a philosopher and theologian. In A Common Faith, Dewey sought to remove the religious aspect of experience from the "historic encumbrances" of dogma and institutions (1934:6). He saw the religious as a "clear and intense conception of a union of ideal ends with actual conditions," of "ideal possibilities unified through imaginative realization and projection" (Dewey 1934:51-52). What Dewey is describing here is imagination, the ability to imagine something better and then work with others to make it happen, bring about that different reality. ${ }^{54}$ Dewey called on people to work on "behalf of an ideal end against obstacles and in spite of threats of personal loss because of conviction" of the "general and enduring value" of the ideal end (Dewey 1934:27).

The origins of computer culture, online activism and the hacker ethic are imaginative in nature, in the Deweyan sense, and can be traced back to an earlier generation of activists. The creator-hackers who built and fought for the open networks are both biological and cultural products of the 1950-60s social revolution(aries). They participated in the counterculture that was born out of the revolutionary calls of the Students for a Democratic Society, experiments with LSD and other psychoactive consciousness expansion, psychedelic culture, free speech,

54 I first began writing about imagination in online activism while working on activism as religious action via theologians such as Eliade and Tillich. Dewey (1934) addresses similar ideas from a secular perspective via philosophy. I recently also found Boellstorff's discussions on imagination in digital anthropology (Boellstorff 2012). 
civil rights and feminist and queer liberation struggles, among other movements and social changes.

The counterculture manifesto which founded the Students for a Democratic Society, The Port Huron Statement, asks "what is the perimeter of human possibility in this epoch?" and “what role have we ourselves to play as a social force?" (Hayden 2005:151). Perhaps The Port Huron Statement defines their proposed path to social justice best when it suggests undertaking "the search for truly democratic alternatives to the present, and a commitment to social experimentation with them" (Hayden 2005: 48). The manifesto expresses optimism about the potential of humankind, "we regard men as infinitely precious and possessed of unfulfilled capacities for reason, freedom and love" (Hayden 2005:51) and prescribes the specific goal of acting on the moral demand of this optimism:

The goal of man and society should be human independence: a concern not with image of popularity but with finding a meaning in life that is personally authentic; a quality of mind not compulsively driven by a sense of powerlessness, nor one which unthinkingly adopts status values, nor one which represses all threats to its habits, but one which has full, spontaneous access to present and past experiences, one which easily unites the fragmented parts of personal history, one which openly faces problems which are troubling and unresolved; one with an intuitive awareness of possibilities, an active sense of curiosity, an ability and willingness to learn. (Hayden 2005:52)

In specifying the "goal of [. . . ] society," The Port Huron Statement imagines not merely changes in favor of social justice, but the establishment of an entirely new system:

As a social system we seek the establishment of a democracy of individual participation, governed by two central aims: that the individual share in those social decisions determining the quality and direction of his life; that society be organized to encourage independence in men and provide the media for their common participation. [Hayden 2005:53]

Especially relevant here is the "media for their common participation." Perhaps the authors of The Port Huron Statement didn't intend the word to be taken so literally, but in the 40 years 
since, one candidate for that participatory space could be the Internet and the new networked social spaces that have emerged online and offline as a result of the connectivity of the net.

But how do Internet users act in these new social spaces? And what is the value of that "action" in cyberspace? What effect does it have? It is because these network communication technologies have been effectively used as counter-power that hegemonic powers perceive open systems in cyberspace as a threat. Warf and Grimes provide an early example from China:

Some governments have come to fear the Net for its emancipatory capabilities. The Chinese government, for example, was stung by students' use of faxes and email during the 1989 Tienanmen Square massacre. It was especially aggrieved at their use of a network - ChinaNet - based at Stanford University, so it began in early 1996 to limit access to Internet nodes. [Warf and Grimes 1997:262]

In their early work, published just three years after the launch of the World Wide Web, Warf and Grimes go on to assemble a list of documented early instances in which the Internet served as counter-power for the oppressed:

In non-U.S. contexts, Japan's Ainu minority used that nation's emerging Internet system to call attention to threats posed by the construction of Nibutani Dam, as did Okinawans protesting U.S. military bases (Rimmer and Morris-Suzuki 1997). The Web site of the Basque separatist movement ETA [. . . ] was shut down by the Spanish government, ostensibly because of its very effectiveness (Cushman 1997). Shannon O'Lear describes how environmental activists in Estonia and Russia cooperated in using e-mail to combat the degradation of a nearby lake (O’Lear 1996,1997). Dozens of "countrynets" report actions and events in repressive political systems around the world, including China, Burma, Kenya, and East Timor, often providing material that is not available through traditional media (Neumann 1996). In the same vein, the journal Cultural Survival attempts to preserve endangered tribal peoples through its Web site and electronic journal Active Voices [.. .] Similarly, the issue of children's rights, embracing a plethora of matters such as infant mortality, child-labor laws, the effects of divorce on children, and juvenile justice, are discussed. [Warf and Grimes 1997:266]

Delivering the 2007 Nathan W. Levin Lecture at the New School in New York City, Manuel Castells proclaimed "the hackers built the network - and they built it open." 55 Born out of the

55 I attended this lecture and while quote is from my notes during Castells address, the notion is also reflected in 
defense department ARPANET research project, the Internet was a product of "both the "closed world' of the Cold War and the open and decentralized world of the antiwar movement and the counterculture" (Rosenzweig 1998:1531). It takes incredible imagination to begin to understand how a defense department project could have been turned into such a powerful tool for social movements in their struggles for liberation and social justice.

Castells (1996, 1997, 2001). 


\section{Selected Field Notes}

\section{October 13, 2011}

Occupy Together Meetup comment on the October 19th Meetup, before the date/location had been set and it was just called "Let's meet in Jakarta Indonesia":

"I will be there in spirit.

Power to the people defending all life on Earth!

Down with Allied Military Industrial (fossil fuel/ nuke) Complex Inc.

Good Luck." -Posted by John October 13 at 5:25 PM

\section{October 19, 2011}

How does the privitization of public space allow for the public protest of privitization?

How does an anti-corporate group fare in corporate controlled space? (Ads that show up on the group page? Marketing materials?)

What does it mean "to occupy?" Is there an 'invisible' (in that it isn't considered material, but rather just supportive) occupation that actually binds the physical occupation?

What relationship does the online occupation have to the physical for participants?

Looking at the photos posted by Occupy Jakarta, you see images of people holding signs visualization of protest. You see a protest going on on the page.

First the graphic of a man holding a sign, then later a photo of a man holding a sign which is the graphic image of a man holding a sign.

First you have this image as the facebook groups profile picture: (Image of protester holding a sign)

Then you have this image posted later: (Image of protester holding sign depicting protester holding a sign)

While protesting isn't illegal, the police response to a small crown gathering for the first physical occupation was to gather around them and prepare a water canon nearby. The protest was peaceful, lasted for three hours and then disbanded. Did they not "occupy" because they can't? Does the occupation then de facto become one that is online with forays into the physical world-compared to the activity of the occupiers in Liberty Plaza who are primarily engaged in a physical occupation with forays into the online world?

\section{September 25, 2011}

\section{Questions}

How does the public narrative of development and democratization compare with the material support and the on the ground engagements and actions of the U.S. Government and U.S. Military with the Indonesian special forces? How is the "War on Terror" used to set create a zone wherein the competing ideas of oppression and democracy are seen to exist in cooperation? 
How is cyber/digital-space treated as a "frontier" or a "war zone" in which U.S. technology and personnel can act outside the law?

Narratives of Democracy and Cooperation In November, 2009, Barack Obama returned to Indonesia where he had lived as a child and spoke at the University of Indonesia in Jakarta as the U.S. President. He peppered his remarks with words from Bahasa Indonesian, the lingua franca of the archipeligo, and shared memories of his life there as a child in the 1960s. He spoke of flying kites, chasing dragonflies and the mango tree in front of their home. His colorful speech described the transformation of Indonesia in the 40 years since as a progression from "fields with water buffalo and goats" to "cell phones and social networks." The central theme was a new "Comprehensive Partnership between the United States and Indonesia" announced along with President Yudhoyono to promote cooperation on economic, educational and security issues. Obama described Indonesia's process of democratization as "fortified by its checks and balances: a dynamic civil society; political parties and unions; a vibrant media and engaged citizens who have ensured that - in Indonesia — there will be no turning back."

Additional excerpt from Obama's speech "Hand in hand, that is what development and democracy are about - the notion that certain values are universal. Prosperity without freedom is just another form of poverty. Because there are aspirations that human beings share - the liberty of knowing that your leader is accountable to you, and that you won't be locked up for disagreeing with them; the opportunity to get an education and to work with dignity; the freedom to practice your faith without fear or restriction."

Detachment 88 and Cyber/Digital Space Special Detachment 88, a special forces unit of the National Police Force was formed in 2003 following the 2002 Bali bombings. They are funded, equipped and trained by the U.S. and Australia. Human rights lawyer Iwangin Sabar Olif was seized in 2007 by Detachment 88 on the street for sending an SMS message critical of the Indonesian military and president. The SMS message was intercepted by equipment and/or personnel provided by the U.S. And he was charged by the Indonesian government with "incitement and insulting the head of state."

\section{Kopassus}

Allan Nairn, a journalist working in Indonesia, has reported that the Indonesian people refer to the Army Special Forces unit Kopassus as [insert original Indonesian word] which means "sadists." Nairn reports that "it is formal policy of Kopassus to commit terrorism and to kidnap civilians." Human Rights Watch documents how Kopassus soldiers "arrest Papuans without legal authority, and beat and mistreat those they take back to their barracks." In December 2004 human rights advocate Filep Karma was arrested for taking part in a peaceful demonstration during which he raised a Morning Star flag, a symbol of the Papuan independence movement. He was charged with "rebellion" and was convicted of treason for "betraying" Indonesia by raising the flag. He is serving a 15 year sentence in prison.

Assassinations 
Human rights activist and vocal critic of the government and military Munir Said Thalib was poisoned while on a flight from Jakarta to Amsterdam where he was going to study for an M.A. in international law and human rights.

The Zone of Merging Oppression and Democracy

In his book, The Audacity of Hope, Barack Obama (2006) wrote that "for the past 60 years the fate of [Indonesia] has been directly tied to US foreign policy," including "the tolerance and occasional encouragement of tyranny, corruption, and environmental degradation when it served our interests." (How does this acknowledgement translate into Obama becoming president and then continuing to fund that tyranny?)

In July 2010, the U.S. Secretary of Defense, Robert Gates announced that the United States would begin a "gradual, limited program of security cooperation activities with the Indonesian Army Special Forces." Gates continued: "I noted to the president that these initial steps will take place within the limits of U.S. law and do not signal any lessening of the importance we place on human rights and accountability. What's more, our ability to expand upon these initial steps will depend upon continued implementation of reforms within Kopassus and TNI [Indonesian National Armed Forces] as a whole."

In response to requests from the East Timor Action Network that the US Embassy in Jakarta monitor the situation of Iwangin Sabar Olif (arrested for the SMS), the Deputy Office Director from the Bureau Democracy, Human Rights and Labor wrote "According to all available information, the involvement of Detachment-88 in this case was limited and has since ceased because terrorism charges are not being pursued . . . We believe that U.S.-supported training of Detachment-88 . . helps instill professional standards of conduct."

\section{November 27, 2011}

I started this project curious about how Indonesian occupy participants were constructing their movement online, since they didn't have a physical round-the-clock occupation like the one in new york that I had been participating in. Over the course of my research, on November 11, the occupation of Zucotti Park, renamed liberty plaza, was evicted in an early morning raid by the Bloomberg administration. Post eviction, a new landscape presented itself to my research, one in which the tables had been turned and the physical occupation of nyc could no longer be held up as a model for what an occupation ought to look like in the present.

\section{December 5, 2011}

Talking to Bill about research, he's looking at embodiment, and composition in terms of digital interfaces. I describe my project and the image of the protester holding the sign of the protesterhe refers to Derrida's writing on mise en abyme - I think of the Droste effect.

\section{April 28, 2012}

indigineity in indonesia; through the occupy movement; through online activism, narrative, testimonial, text, images; through Facebook 
images, depictions and discussions around indigeniety, freeport, occupy - cyberspace

tensions between Islam and Indigeniety in Indonesia from dutch colonial times to the occupy movement on facebook

indiginiety in indonesia is so easily incorporated into the occupy movement because of the complex definition of masyarakat adat

\section{November 16, 2011}

Doug Rushkoff writes that "while the Occupation of Zuccotti and other places may serve as "reference" points, the real occupation is embodied by those of us in the real world who change our behaviors to reflect our values, and who stand up for what we believe in the conversations occurring all around us."

I began this research wanting to look at whether in places where there wasn't a round-the-clock physical occupation, like Indonesia, if the online occupation was just as "real" and meaningful to participants in the Occupy movement. The Occupation of Zucotti park was held up as the model on which all local occupy groups around the world would judge themselves. With a round-the-clock occupation of Libery Plaza for two months, the physical occupation of OWS was primary. But as of yesterday morning, that occupation, that physical occupation is gone. In its place is a new struggle, or perhaps one that was always there is now moving to the front - the struggle for the mediaspace - the online occupation. The battle for OWS has moved to cyberspace, and the contested spaces are the reports in the press, the responses of the Mayor's office, and how well OWS organizes itself in that space.

A text I received today demonstrates awareness of this: "Meeting at 3 pm today at 60 Wall to discuss: How we take advantage of the raid to become a more dynamic, adaptable, network based, etc. A movement that Goes to different neighborhoods instead of using so much energy to provide services in a park. Please forward this to as many ppl as u can."

How does this shift, wherein the OWS encampment can no longer serve as a living model for Occupy, change the way people engage in the movement in Indonesia?

\section{October 14, 2012}

Sitting at the head of a long table covered in a white paper tablecloth, I listened as Grace taught us the Indonesian words for North, South, West and East. "East," she said - "Timor, we used to call East Timor 'TimTim,' but you definitely can't say that anymore it's not politically correct." She said the words like a conservative evangelical Christian says homosexual.

But she was so sweet, so kind, such a good teacher - they all were. The consulate staff, the viceconsul for economic affairs, the woman in a turtleneck and suit-jacket who spoke to us to open this first Indonesian language class ever taught at the consulate in New York. She was someone important, but I didn't catch who - I came in a little late because my bus was delayed from 
Harlem. When I got out at East 68th and Central Park I jogged over to the consulate to try and make it by 10, the start time of the Saturday class.

The front door of the consulate, a beautiful old building, seemed locked. I went down the steps to the basement entrance. A smiling man behind a sliding glass window greeted me, I said I was there for the language class and he said "upstairs, first floor" - he was so kind. His son was there as well, playing, and his big wide eyes looked me over cautiously. I expected security guards, cameras, state-control - but instead, just kind people.

I signed the log, and headed upstairs. The class was being held in the grand reception room on the main floor of the consulate. Statues from Bali, puppets, paintings, sculptures of Ganesh, artwork everywhere, and chandeliers, crystal chandeliers. There were two long tables set up tea and pastries off to the side, 16 students sitting, all adults of various ages, and a small boy who looked just like the one downstairs. Grace was talking and there was a big screen pulled down with a powerpoint projection on it reading "Beginning Indonesian."

I thought of all this and decided to write it down while was reading an article just now in the Guardian about East Timor and the massacres that took place just after the 1999 referendum on independence:

"The militias had set fire to a small group of macheted victims - men, women and children - in the back of a pickup truck, but the fire had gone out prematurely. There were hundreds of tornup ID cards in a hut nearby, and the bodies of two women who had evidently been violently raped. Aitarak ("Thorn"), the name of one of the most notorious militia groups, was written in bright blood on a wall nearby."

"Selemat pagi!" She said, "Selemat pagi!" the class repeated. Good morning she said.

And later, lessons reflect echoes of colonialism, not Indonesia's colonialism of Timor or Papua this time, but the Dutch colonialism of Indonesia. A Dutch flag is up on the screen-we're learning the names of countries. "Belanda" Grace says - "Netherlands, an important one! Since they colonized us for hundreds of years! And when you're there, they will call you 'londo which comes from the 'Belanda' and means 'white foreigners' - it doesn't matter if you're not dutch, everyone white is 'londo.'

Timor-Leste is not part of this lesson, that bit just slipped in during the discussion of the compass rose. "Utara, Selatan, Barat, Timur" - North, South, West, East, Grace says as she draws a cross and labels the directions, and then another at 45 degree angle for the half-way bearings. Northwest (barat laut) and Northeast (timur laut) both end with the word for "sea" (laut). Grace says that one student of hers suggested this is because Indonesia is so Java centric that if you put the center of the compass rose on Java, the NW and NE are both ocean.

"Ibu-Ibu, Bapak-Bapak” - "Ladies and Gentlemen...” Grace says. I wonder what would happen if you put the center of the compass rose on the Amsterdam? The same thing, North of the Netherlands, it's all sea. 
The class ends with Grace passing out CDs. The CD comes in a beautiful blue envelope with scuba divers on the front and a colorful logo that reads "wonderful indonesia" and advertises “Alor, Belongas Bay \& Weh.” It's apparently a video about underwater tourism. The back says "Directorate General of Tourism Marketing, Ministry of Tourism \& Creative Economy, Republic of Indonesia”

Alor is a one thousand square mile island East of Java and just above Timor - vanilla, tamarind, almonds and sandalwood grow here. The Indonesian government hopes for diving tourism, although the coral reefs have been damaged by over-fishing, the story of resource extraction across Indonesia.

\section{October 19, 2012}

An e-mail sent to Yukiko Koga, my thesis advisor:

I've been reading Stoler's Imperial Debris as you suggested, and it's really useful. A lot of the other work I've been reading seems interested in finding unity across the nation, dealing with an Indonesian subject, where a previous generation had looked at it more ethnolocally, like only Java or only Bali or even smaller. But in that turn toward the unity and in looking for similitude, there seems to be failure to account for what thinking of as a colonial echo (producing both divisions and unity in different ways) - and Stoler's imperial debris lens is helpful in reframing that. Just now getting into the article, and giving it lots of time and a careful reading as you suggested.

The more I work on my project, the more I see that my interest lies in these areas and not in Indonesian studies per se. In other words, it's not Indonesia as a culture/region, but rather that it's a really rich site of the broader things I'm interested in.

The Agamben we read in Law was hugely inspiring for me along with your work, which was unlike anything I'd heard about before. Everything around the areas of empire, colonial legacy, state power and its effects on people as well as their collective and personal responses to it - and around questions of human rights, justice, etc. Prior to adding the anthro major, I was focused on looking at social justice through the intersections of religion and technology and this usually meant looking at social movements which were organized around responses to injustice. I wrote about Burma and about Foxcon factory workers in China, etc. - the liberating promise of the technology they are manufacturing in contrast to their experiences as subjects of the factory life, etc. So I think that's these issues are the constant thread through it all.

\section{October 19, 2012}

I've just discovered the story of Alexander Aan, (born circa 1982) an Indonesian man who was reported to the Indonesian police by the Indonesian Council of Ulema for his posts on a Facebook page where he was an administrator. He wrote "God does not exist." (MacKinnon 2012) 
He was a civil servant from Pulau Punjung, in West Sumatera - an active member of the "Minang" atheist Facebook group. On 18 January 2012, an angry crowd who heard about his posts gathered at his work and threated to beat him. Police intervened and took him to Pulau Punjung Sub-District police station for "his safety."

On 20 January he was charged for "disseminating information aimed at inciting religious hatred or hostility" under Article 28 (2) of the Electronic Information and Transaction (ITE) Law, religious blasphemy under Article 156a(a) of the Indonesian Criminal Code and calling for others to embrace atheism under Article 156a(b) of the same code.

His trial began at the Muaro District Court on 2 April 2012. On 14 June the court sentenced him to two and a half years' imprisonment and a fine of 100 million rupiah (US\$10,600) for violating the Electronic Information and Transaction (ITE) Law.

\section{October 20, 2012}

Watching several films today. The first, Bilabo, a dramatic recreation of the Invasion of Timor by Indonesian forces. The second, The Diplomat, a documentary following Jose Ramos as he works outside of Timor for independence. The third, Forgotten Bird of Paradise, about the Papuan Independence Movement (OPM).

In the film Melinda Janki, human rights lawyer, states that the "act of free choice" mandated by the UN after the Dutch gave Papua independence, was conducted by a Javanese process called $X X X X$, which is based on consensus and does not allow dissent:

"When Indonesia held the act of self-determination, ironically called the act of free choice, perhaps we could just consider what actually happened in the act of free choice: 1,026 people were handpicked by the Indonesian government, less than $0.2 \%$ of the population. There was no vote by the 1,026 people, they had to reach decisions by a Javanese system known as Musyuwara, consensus, which does not allow dissent or opposition. This discussion took place in the presence of the army, the information services, and the government. It was not a valid exercise of self-determination.

It's an established principle of international law that a colonial people have a right to independence, they have a right to the restoration of their inherent sovereignty that was illegitimately taken by a colonial power. And as you know, colonialism is contrary to the charter of the united nations and it is therefore illegal."

\section{February 2, 2013}

Reading Marc's review article on Social Movements today. Full of useful theory and frameworks for understanding social movements.

Questions that I need to be asking and answering in my research:

Is Occupy a transnational social movement, or something else? A network, a coalition? 
What is the history here? Is it the Occupy movement or just the Occupy discourse being applied to local, pre-existing movements, networks or causes?

What kind of continuities exist in the membership with previous movements in Indonesia? There must be a history to the people involved-for example some of them might have been involved in the student protests that unseated Suharto, some were already involved in the Papuan independence movement, the anti-corruption movement, LGBT groups, etc. Anonymous, etc? What brought them together, what brought them to Occupy? Is it about identity, about resource mobilization, about a social cleavage, about way of life, about economic change in Indonesia, about development?

\section{February 7, 2013}

Through the readings and discussions for the first week of the transnational social movements seminar, I'm starting to see Occupy in Indonesia and my investigation of it differently.

I'd like to try and answer the following questions:

Why do existing, local causes in or around Indonesia (ex. Papuan independence) operate under the Occupy banner - for example, Eben's talk at Occupy on Papau. Was that a coalition with the transnational Occupy movement, or?

Do members, and founders of Occupy Indonesia have a history of activism? Were they involved in the student uprisings that led to the democratization? (Article about protest traditions in Indonesia that I saw somewhere)

Does Occupy function as a transnational social movement, or is it more like a template or discourse or label that lends transnational legitimacy to other movements who take it on? If so, what are the characteristics? It seems that there are no requirements or tests or engagement with power structures needed to claim Occupy membership - therefore it's a way of transnationalizing your existing movement - but why would you want to do that, what are the benefits?

\section{February 22, 2013}

"110 million people in Indonesia who live on less than $\$ 2$ a day."

-Jacqui de Lacey - Head of AusAid, Indonesia in Pulse Lab Jakarta video

"Use of mobile devices growing significantly. Today we have 180 million mobile users in Indonesia and close to 50 million Internet users. That shows that IT technology is being used by almost everybody."

Betty Alisjahbana, Ambassador for Open Source, Indonesia

\section{March 10, 2013}

I realize that I need to focus in and get some research questions written down. 
How does the Indonesian Occupy movement fit into the history of activism and social movements in Indonesia?

How does occupy fit into the remains of empire, how does colonial history inform engagements with Occupy and social movement work on issues of current colonial occupation, like in Papau? What can be learned from looking at the biographies of social movement activists in Indonesia? Do they show connections between Occupy and previous movements, like the student protests of the 1990s?

Why was the Occupy discourse adopted, what was it that made sense about Occupy to the people in Indonesia who became interested in it?

What place does online activism have in Indonesian political activity? In light of situations like Alex Aan, arrested for writing about Atheism on Facebook.

\section{March 12, 2013}

What about looking at the Indonesian Occupy Movement from the perspective of an unsuccesful mobilization? If I look at it from that angle, what do I discover about it?

The answer about Occupy online is somewhere between the technological "solutionism" that claims twitter and facebook will bring social justice to the world (actually a strawman) and the belief that social media engagements by social movements don't mean anything (an argument I actually hear in response to the strawman).

Additionally - simply because you look at a thing doesn't mean you are endorsing it as the most important thing to look at, the most influential thing, the most powerful factor, the most essential characteristic, etc.

\section{April 11, 2013}

From A.E. van Vogt's "World of Null-A”:

"Because of the limitations of his nervous system, Man can only see part of truth, never the whole of it. In describing the limitation, Korzybski coined the term "ladder of abstraction." Abstraction, as he used it, did not have a lofty or symbolical thought connotation. It meant, "to abstract from", that is, to take from something a part of the whole. His assumption: in observing a process of nature, one can only abstract-i. e. perceive-a portion of it.

Now, if I were a writer who merely presented another man's ideas, then I doubt if I'd have had problems with my readers. I think I presented the facts of General Semantics so well, and so skilfully, in World of Null-A and its sequel that the readers thought that that was all I should be doing. But the truth is that I, the author, saw a deeper paradox.

Ever since Einstein's theory of relativity, we have had the concept of the observer who-it was stated - must be taken into account. Whenever I discussed this with people, I observed they were not capable of appreciating the height of that concept. They seemed to think of the observer as, essentially, an algebraic unit. Who he was didn't matter. 
In such sciences as chemistry and physics, so precise were the methods that, apparently, it did not matter who the observer was. Japanese, Germans, Russians, Catholics, Protestants, Hindus, and Englishmen all arrived at the same impeccable conclusions, apparently bypassing their personal, racial, and religious prejudices. However, everyone I talked to was aware that, as soon as members of these various nationalities or religious groups wrote history-ah, now, we had a different story (and of course a different history) from each individual.

When I say above that "apparently" it didn't matter in the physical sciences, or the "exact sciences" as they are so often called, the truth is that it does matter there also. Every individual scientist is limited in his ability to abstract data from Nature by the brainwashing he has received from his parents and in school. As the General Semanticist would say, each scientific researcher "trails his history" into every research project. Thus, a physicist with less educational or personal rigidity can solve a problem that was beyond the ability (to abstract) of another physicist.

In short, the observer always is, and always has to be a "me” . . a specific person."

\section{July 18, 2013 (East Java)}

Fasting

Walking in the evening, I see Indonesians preparing to break the fast (berbuka puasa). The day is divided into sections and the language both reflects an interest in these periods and provides further re-enforcement of their existence.

Pagi: very early morning, until 10 or 11

Siang: from 10 or 11 until 3pm, when the sun feels high and is clearly up

Sore: from 3pm until the sun begins to set, or until sunset

Petang: the time of sunset, but rarely used in Malang, East Java

Malam: after the sun has set, during the darkness until early morning

During Ramadhan, the Muslims here in East Java fast from sun-up to sun-down. Getting up early at 2:30 or 3 am for breakfast and then sleeping again. The calls to prayer are louder, more frequent, and earlier - I feel. But I don't know if that's only my perception. Also, there appears to be a 'sermon' that some mosques broadcast throughout the day and night, which is more than the call to prayer, longer.

In response to my frustrated post on Facebook about the noise keeping me up all night, one Indonesian friend replied: "hahha. sabar mas. All night means "Tadarus". mereka membaca Al Quran sepanjang malam." (Hakim)

\section{Technology}

Kepanjen, East Java

In a village full of small homes, surrounded by rice fields, cassava and corn fields and tree plantations - an hour outside of Malang by train - a village full of homes seemingly in disrepair, but with beautiful collections of houseplants and birds in cages - I found at Adi's house a desktop computer, a wireless modem, and a laptop. Adi brought his own laptop and so there were three computers in the home all online. His aunt, who runs the household cooked us a meal 
of traditional foods to break the fast, fried tempe (goring tempe), fried tofu (goring tabu) and vegetables, peanut sauce (samba pecel), and white rice. She has a water reservoir on the roof that is fed from a well which sometimes overflows and floods down the walls of her kitchen. And yet, she also has a cell phone and a laptop and a desktop. She showed me all of her friends on Skype who she talks to regularly - all over the world, India, Japan, Europe... And while we were sitting and talking after dinner, as the mosque in the village began to beat the drum calling everyone to the special 6th prayer for Ramadhan (tarawih), she and I became Facebook friends she added me from her laptop and I accepted the request from my Indonesian mobile phone (HP: handphone) sitting next to her. Boys from the village were playing in the room with her sons, Adi's cousins - one of them in the traditional shirt and hat of a muslim man - holding RL Stine's goosebumps book.

There is an often repeated perception of a significant digital divide in Indonesia, and in places that are developing like Indonesia. But what I found is that everywhere, no matter how small the village, how remote the homes - from a family of banana pickers living in a Village, to the tea plantation workers at Wonosari tea factory, to Adi's relatives in Kepanjen - Indonesians all have mobile phones (HP: handphones) and they all have access to the internet. They use them to read news, to use GPS maps, to go on twitter and Facebook, but especially to SMS.

\section{Code Switching}

During Ramadhan, television is full of advertisements for special SMS packages. SMS is the preferred method of communicating, not calling, but SMS - with teachers, with parents, administrators and friends. One student's thesis that I helped to edit at Universitas Negeri Malang, was on code switching in text messages between students and faculty at the university. She found that students switched into the language used by the person with the most power in the relationship. If they wrote to the lecturer in english and she replied in BI, they would continue in $B I$ - and visa versa.

\section{Ghosts}

While in Kepanjen I heard bamboo squeak for the first time. I asked Adi's two friends about it they said that the ghosts (hantu) do live in the bamboo (pohon bambu). They also said that I couldn't pee (buang air kecil) on the trees because the myth was that that would make them angry and they might take revenge.

\section{August 23, 2013}

Technology in an Indonesian Village (Java)

Small farming communities surrounded by rice fields where residents grow cassava in their yards, keep birds in cages. Adi's aunt grew turmeric and several other spices that she used to make sauce pecel, in her garden. These houses are rough looking, in need of paint, often lit with single bulbs hanging from the ceiling - are home to several family members, across generations. They're often nearby other family. Adi's family home was just around the corner from his uncle's house, and he said he had many cousins there in the village. His friends parents made snacks in their home (home industry, an English phrase often used in Indonesian). 
And yet inside Adi's home, there were two-three laptops, one desktop computer, a high speed internet connection, wireless, satellite TV, and a printer. His cousin was deep into video game play for most of the time that I was there. His Aunt, after dinner, showed me her laptop, and how on Skype she had friends from all over the world, who live all over the world. While in her apartment, she showed me her Facebook account and we became friends right then and there.

In addition to these direct and obvious internet connectivity and computer technology, she had a mobile phone that was capable of using many of the same apps, of going online to use Facebook, Skype, etc. I didn't meet anyone in Indonesia who didn't have a phone with internet access.

In part, getting mobile phones and then getting them online is a much easier and cheaper endeavor than it is in the United States. One a phone is purchased, rather than signing up for a contract, users can simply add "Pulsa" (points, minutes, credits) to the phone. These credits can be purchased in small shops that sell snacks, food and other things (what in NYC is called a "bogeda" or "corner store"), or in dedicated "Pulsa" shops that sell points for mobile phones (all providers use different points) or for USB modems. Once purchased Pulsa can be used to purchase internet plans that allow unlimited or quota based browsing of the internet, chat, or SMS. This pay-as-you go structure allows access to the internet without the investment or financial commitment of a plan or contract. It also means that internet activity can more easily 'wax' and 'wane' with the user's needs, buying Pulsa and plans when needed and keeping the number and access available when not needed.

\section{An Academic Alone in a Green University}

My host father said Universitas Negeri Malang was becoming what they call a "Green University" meaning that the campus population was becoming more Muslim, and the university administration and academic life was reflecting this change. I was also told by several informants that the mosque on campus was one of the more conservative in the area. And interesting fact considering the way that this mosque occupied an important role in the student's lives whom I was friends with. My tutor Adi would pray five times each day, and this often meant going to the mosque on campus when he was there for school, or to work with me.

For my final project, I presented on the Indonesian Occupy movement-specifically on the language they used. My topic was how the indonesian social movement adopted the globalizing Occupy discourse using the word Occupy rather than the Indonesian word Duduki. After the project, I was approached by a student at the university (Ahmed), I believe an S2 (MA) student who told me he wanted to know more about my research. He expressed interest in my paper which I sent to him, and also wanted to tell me about his thoughts on the movement. He said that when he had talked about Occupy with colleagues at the university they had called him a "traitor." He agreed to talk to me more about the movement in the future and I look forward to interviewing him.

\section{Indonesian/Javanese Facebook Etiquette}

I noted early on that when I became friends with people in Indonesia that Javanese rules of politeness seemed to apply. After accepting their requests, they would often respond by posting on my wall "Terimah kasih Mas!" Literally meaning "Thank You Mister!” but really in that context more like "Thanks, man!" This tradition of thanking users for being friends on Facebook makes public each act of friending, each new friend becomes not only an announcement on the timeline by Facebook, but a proclamation by the involved party, and a thanks for the acceptance. 
We were repeatedly told in Indonesia that Indonesian culture is focused on community, on the group, rather than the individual. One way this was expressed is in the use of the word "sendiri" as a question - asking "alone?". This question came with the connotation that one is better of not being alone, and probably wouldn't prefer it - something along the lines of "what's wrong?" or "you OK?" in American English. The question suggests that the person being asked has been abandoned by the normal social environment and probably feels slighted by it. This occurred even though the Indonesian people asking (often tutors or teachers) were trained in advance to know that we might enjoy having time alone.

"Hello Mister!" \& "Photo, Photo!"

Walking down the sidewalk or street in East Javanese town, even one with 3 million people like Malang meant frequently being addressed by Indonesians as "Mister" and asked to take a photo along with people. It was hard to figure out what was going on with this. It struck me that this was both because non-Indonesians were a relatively rare sight, but also because we simply looked so strange and different. Tall, paler skin, different clothing, different ways of walking (techniques of the body seems to apply here)... I couldn't help but see my fellow "bule" as big puppets, like the characters who walk around in theme parks, we were mascots for "The West" and for "America."

\section{September 9, 2013}

Incorporate Appadurai's 'scapes - chap 10, towards a transnational anthropology.

How does this map onto the changing landscapes of indigenous people? Space becomes cyberspace, and a sacred mountain becomes a mine - then that is "occupied" through action in cyberspace - my question - what's going on there, and what does it mean.

Look at article from Greider \& Garkovich "Landscapes: The Social Construction of Nature and the Environment"

Something is happening with the transitions from physical to cyber, from sacred to resource extraction, from activist occupation of space to activist occupation (as in residence) on Facebook. Maybe Facebook is actually serving as a kind of distraction here - but isn't everything? And can't the workers organize while they're at the mine, can't the activists organize while they're in cyberspace - regardless of the complications with the space or structure they're in?

\section{October 13, 2013}

Cyberspace becomes the perfect environment for working out gaps in collective memory, for reworking existing memory, and for constructing new histories.

It's a great terrain for people to come together share what they know, find the gaps, fill them in build new stories.

Thus the occupation of cyberspace is a means by which activists can occupy memory. 
This is the connection between the cyberactivism, the occupation of cyberspace and memory.

Like wikipedia, the collaborative, open sourced building of knowledge, what tool is there for memory to be built this way? The small bites of experience, of proclamation, the small things said by activists together in groups and on walls/timelines of pages - they come together to create a narrative that is shared.

\section{November 1, 2013}

Reading the forward and preface to LOTR, Tolkien explains that his novel is not allegorical, but rather historical and applicable:

"But I cordially dislike allegory in all its manifestations, and always have done so since I grew old and wary enough to detect its presence. I much prefer history, true or feigned, with its varied applicability to the thought and experience of readers. I think that many confuse 'applicability' with 'allegory'; but the one resides in the freedom of the reader, and the other in the purposed domination of the author." 


\section{BIBLIOGRAPHY}

Abram, David

1997 The Spell of the Sensuous: Perception and Language in a More-than-human World. Vintage.

Amnesty International

2011 "Indonesia: Release participants of peaceful gathering in Papua" Amnesty International Index Number: ASA 21/033/2011, 20 October 2011

(http://www.amnesty.org/en/library/info/ASA21/033/2011/en)

Ananta, Aris, Evi Nurvidya Arifin, Leo Suryadinata, and Institute of Southeast Asian Studies 2005 Emerging Democracy in Indonesia. Institute of Southeast Asian Studies.

Bakht, Maryam M.

2010 "Lexical Variation and the Negotiation of Linguistic Style in a Long Island Middle

School". New York University.

Bellafante, Ginia

2011 Protesters Are Gunning for Wall Street, With Faulty Aim. The New York Times, September 23. http://www.nytimes.com/2011/09/25/nyregion/protesters-are-gunning-forwall-street-with-faulty-aim.html, accessed October 11, 2013.

Barendregt, Bart

2006 Between M-governance and mobile anarchies: Pornoaksi and the fear of new media in present day Indonesia. In EASA Media Anthropology Network e-Seminar. Vol. 28.

Barker, Joshua

N.d. "Engineers and Political Dreams: Indonesia's Internet in Cultural Perspective." Faculty Profile, Research Project Description. http://www.anthropology.utoronto.ca/people/ faculty-1/faculty-profiles/joshua-barker, accessed November 30, 2013.

Biehl, João

2013 Ethnography in the Way of Theory. Cultural Anthropology 28(4): 573-597.

Boellstorff, Tom

2005 The Gay Archipelago: Sexuality and Nation in Indonesia. Princeton Univ Pr.

2008 Coming of age in Second Life: An anthropologist explores the virtually human.

Princeton Univ Pr.

Boellstorff, Tom, George E. (FRW) Marcus, Bonnie Nardi, Celia Pearce, and T. L. L. Taylor. 2012 Ethnography and Virtual Worlds: A Handbook of Method. Princeton University Press.

Brosius, Peter J., Anna Lowenhaupt Tsing, and Charles Zerner, eds. 
2005 Communities and Conservation: Histories and Politics of Community-Based Natural Resource Management. Altamira Press.

Budianggoro, Nugroho

2011 "Occupy Jakarta begins in Indonesia." Demotix.

http://www.demotix.com/news/885461/occupy-jakarta-begins-indonesia, accessed

September 16, 2012

Calhoun, Craig

1993 "New Social Movements" of the Early Nineteenth Century. Social Science History 17(3): 385-427.

Caren, Neal and Sarah Gaby

2011 Occupy Online: Facebook and the Spread of Occupy Wall Street.

http://ssrn.com/abstract=1943168, accessed October 24, 2011

Castells, Manuel

1996 The Rise of the Network Society. Cambridge, MA; Oxford: Blackwell Publishers.

1997 The Power of Identity. Cambridge, Mass ; Oxford: Blackwell.

2001 The Internet Galaxy : Reflections on the Internet, Business, and Society. Oxford ; New

York: Oxford University Press.

Clifford, James

1988 The Predicament of Culture: Twentieth-century Ethnography, Literature, and Art.

Harvard Univ Pr.

Chaturvedi, Vinayak

2000 Mapping Subaltern Studies and the Postcolonial. Verso Books.

Coll, Steve

2012 Private Empire: ExxonMobil and American Power. Penguin.

Cutler, Kim-Mai

2010 "Indonesia Eclipses the UK as Facebook's Second Largest Market"

http://www.insidefacebook.com/2010/11/02/indonesia-facebook/, accessed September 16, 2012

Cybriwsky, Roman and Ford, Larry R.

2001 City profile: Jakarta. Cities 18(3): 199-210

Dabashi, Hamid

2013 Can non-Europeans Think?

http://www.aljazeera.com/indepth/opinion/2013/01/2013114142638797542.html, accessed November 5, 2013.

Davis, Erik 
2004 TechGnosis : Myth, Magic + Mysticism in the Age of Information. Vol. Updated. London: Serpent's Tail.

Derrida, Jacques

2001 "On Forgiveness," in On Cosmopolitanism and Forgiveness, trans. Mark Dooley and Michael Hughes. London and New York: Routledge, 25-60.

2006 Specters of Marx: The State of the Debt, the Work of Mourning and the New

International. Routledge.

Dewey, John

1934 A Common Faith. New Haven: Yale University Press.

Eckert, Penelope, and Sally McConnell-Ginet

1992 "Think Practically and Look Locally: Language and Gender as Community-based

Practice.” Annual Review of Anthropology 21: 461-490.

Edelman, Marc

2001 Social Movements: Changing Paradigms and Forms of Politics. Annual Review of

Anthropology 30: 285-317.

2005 The Anthropology of Development and Globalization: From Classical Political

Economy to Contemporary Neoliberalism. Wiley-Blackwell.

Firman, Tommy

2004 New town development in Jakarta Metropolitan Region: A perspective of spatial segregation. Habitat International 28(3): 349-368.

1998 The restructuring of Jakarta Metropolitan Area: A "global city" in Asia. Cities 15(4): 229-243.

Foucault, Michel, and Colin Gordon

1980 Power/knowledge: Selected interviews and other writings, 1972-1977. Vintage.

Goodman, Amy, and Alan Nairn

2007 "US Intelligence Tapping Phones of Indonesian Civilians." Democracy Now!

http://www.democracynow.org/2007/12/13/us_intelligence_tapping_phones_of_indonesian

, accessed September 16, 2012

Grazella, Mariel

2012 Billionaires Club Grows Fastest in Indonesia. The Jakarta Post, September 28. http://www.thejakartapost.com/news/2012/09/28/billionaires-club-grows-fastestindonesia.html, accessed May 10, 2013.

Habermas, Jürgen, Judith Butler, Charles Taylor, and Cornel West

2011 The Power of Religion in the Public Sphere. Columbia University Press.

Hafild, Emmy 
2005 "Social Movements, Community-based Natural Resource Management, and the Struggle for Democracy; Experiences from Indonesia." in Brosius, J. Peter, Anna Lowenhaupt Tsing and Charles Zerner. Communities and Conservation. Histories and Politics of Community-Based Natural Resource Management: 257-268.

Haggard, Stephan, and Sylvia Maxfield 1996 The Political Economy of Financial Internationalization in the Developing World. International Organization 50(01): 35-68.

Han, Sun Sheng and Basuki, Ann 2001 The spatial pattern of land values in Jakarta. Urban Studies 38(10): 1841-1857

Harvey, David

1973 Social Justice and the City. Johns Hopkins Studies in Urban Affairs. [Baltimore]: Johns Hopkins University Press. 2011 "The Party of Wall Street Meets its Nemesis." Versobooks.com.

http://www.versobooks.com/blogs/777-david-harvey-the-party-of-wall-street-meets-itsnemesis, accessed September 16, 2012

Hayden, Tom, and Students for a Democratic Society (U.S.) 2005 The Port Huron Statement : the Visionary Call of the 1960s Revolution. New York [Berkeley, Calif.]: Thunder's Mouth Press ; Distributed by Publishers Group West.

Hayot, Eric, and Edward Wesp 2009 Towards a Critical Aesthetic of Virtual-world Geographies. Game Studies 9(1).

http://gamestudies.org/0901/articles/hayot_wesp_space, accessed November 12, 2013.

Himanen, Pekka, Linus Torvalds, and Manuell Castells

2002 The Hacker Ethic. Random House Trade Paperbacks.

Holmes, Janet and Miriam Meyerhoff

1999 "The Community of Practice: Theories and Methodologies in Language and Gender Research." Language in Society 28 (2): 173-183.

Howe, Craig

1998 “Cyberspace Is No Place for Tribalism.” Wicazo Sa Review 13 (2): 19-28.

Imbun, B.Y.

2000 "Mining Workers or 'Opportunist' Tribesmen?: A Tribal Workforce in a Papua New Guinea Mine.” Oceania: 129-149.

Juris, Jeffrey S.

2008 Networking Futures: The Movements Against Corporate Globalization. Duke University Press Books.

2012 Reflections on \#Occupy Everywhere: Social Media, Public Space, and Emerging Logics of Aggregation. American Ethnologist 39(2): 259-279. 
Klastrup, Lisbeth

2003 A Poetics of Virtual Worlds. Proceedings of MelbourneDAC2003.

http://www.hypertext.rmit.edu.au/dac/papers/Klastrup.pdf, accessed November 12, 2013. 2009 The Worldness of EverQuest: Exploring a 21st Century Fiction. Game Studies 9(1).

http://gamestudies.org/0802/articles/klastrup, accessed November 12, 2013

Koch, Christopher J.

1978 The year of living dangerously. Grafton. London.

Koga, Yukiko

2008 The Atmosphere of a Foreign Country': Harbin's Architectural Inheritance. Consuming the Entrepreneurial City: Image, Memory, Spectacle. Anne M. Cronin and Kevin Hetherington, Eds: 221-253.

2013 Accounting for Silence: Inheritance, Debt, and the Moral Economy of Legal Redress in China and Japan. American Ethnologist 40(3): 494-507.

Kreimer, Seth F.

2001 "Technologies of Protest: Insurgent Social Movements and the First Amendment in the Era of the Internet." University of Pennsylvania Law Review 150 (1): 119-171.

Lave, Jean and Etienne Wenger

1991 Situated Learning: Legitimate Peripheral Participation. Cambridge Univ Pr.

Leaf, Michael

1994 The suburbanization of Jakarta: A concurrence of economics and ideology. Third World

Planning Review 16(4): 341-356.

Lee, Doreen

2011 Styling the Revolution Masculinities, Youth, and Street Politics in Jakarta, Indonesia. Journal of Urban History 37(6): 933-951.

Leith, Denise

2003 The Politics of Power: Freeport in Suharto's Indonesia. University of Hawaii Press.

Lucas, Adam

1996 “Indigenous People in Cyberspace.” Leonardo 29 (2): 101-108.

Marcus, George E.

1999 Critical Anthropology Now: Unexpected Contexts, Shifting Constituencies, Changing

Agendas. School of American Research Press Santa Fe, NM.

Miller, Daniel

2011 Tales from Facebook. Polity.

Muradi, N. 
2009 "The 88th Densus AT: The Role and the Problem of Coordination on Counter-

Terrorism in Indonesia." Journal of Politics and Law 2 (3): P85.

Obama, Barack

2006. The audacity of hope: thoughts on reclaiming the American dream. Random House Digital, Inc.

2010 Remarks by the President at the University of Indonesia in Jakarta, Indonesia. The White House. http://www.whitehouse.gov/the-press-office/2010/11/10/remarks-presidentuniversity-indonesia-jakarta-indonesia, accessed September 16, 2012

Oman-Reagan, Michael P.

2012 "Occupying cyberspace: Indonesian cyberactivists and Occupy Wall Street." Critical Quarterly 54(2):39-45.

Oppenheimer, Joshua, Christine Sine, and Anonymous

2012 The Act of Killing. (Film)

Osterweil, Michal

2013 Rethinking Public Anthropology Through Epistemic Politics and Theoretical Practice. Cultural Anthropology 28(4): 598-620.

Pascoe, Cheri J.

2011 Dude, You're a Fag: Masculinity and Sexuality in High School, With a New Preface. Univ of California Press.

Pellow, David N.

2007 Resisting Global Toxics: Transnational Movements for Environmental Justice. The MIT Press.

Pemberton, John 1987 "Musical Politics in Central Java (or How Not to Listen to a Javanese Gamelan)." Indonesia (44): 17-29.

Power, M., and J. D. Sidaway

2005 Deconstructing Twinned Towers: Lisbon's Expo'98 and the Occluded Geographies of Discovery. Social \& Cultural Geography 6(6): 865-883.

Rachman, Anita

2011 “Occupy Jakarta? We Might if We Knew We Were Being Invited.” Jakarta Globe, October 17. http://www.thejakartaglobe.com/home/occupy-jakarta-we-might-if-we-knewwe-were-being-invited/472078, accessed November 6, 2011

Ricklefs, M. C.

2001 A History of Modern Indonesia since c. 1200. Stanford Univ Pr.

Rifai-Hasan, PA. 
2009 "Development, Power, and the Mining Industry in Papua: A Study of Freeport Indonesia." Journal of Business Ethics 89: 129-143.

Rosenzweig, Roy

1998 "Wizards, Bureaucrats, Warriors, and Hackers: Writing the History of the Internet." The American Historical Review 103 (5): 1530-1552.

Roy, Arundhati

2004 An Ordinary Person's Guide to Empire. Cambridge, Mass.: South End Press.

Sarwono, S.W.

1998 "The Amungme and the Kamoro in Mimika Timur." In Perspectives on the Bird's Head of Irian, Jaya, Indonesia: Proceedings of the Conference, Leiden, 13-17 October 1997, 351.

Spivak, Gayatri Chakravorty

1988 "Can the Subaltern Speak?" in Marxism and the Interpretation of Culture. Eds. Cary

Nelson and Lawrence Grossberg. Urbana, IL: University of Illinois Press, 271-313.

Stahn, Carsten

2001 Accommodating Individual Criminal Responsibility and National Reconciliation: The

UN Truth Commission for East Timor. American Journal of International Law: 952-966.

Stoler, Ann L.

2008 "Imperial debris: reflections on ruins and ruination." Cultural Anthropology 23(2):191219.

2010 Along the archival grain: epistemic anxieties and colonial common sense. Princeton

Univ Pr.

Stoler, Ann L., and Karen Strassler

2000 "Castings for the Colonial: Memory Work in' New Order' Java." Comparative Studies in Society and History 42(1):4-48.

Tsing, Anna L.

2007 "Indigenous Voice." Indigenous Experience Today: 35-68.

2005 Friction: An Ethnography of Global Connection. Princeton Univ Pr.

Tolkien, John Ronald Reuel

2004 Lord Of The Rings. Houghton Mifflin.

US Department of Commerce

2011 National Income and Product Accounts, Gross Domestic Product: Fourth Quarter and Annual 2010 (Third Estimate), Corporate Profits: Fourth Quarter and Annual 2010, Bureau of Economic Analysis.

http://www.bea.gov/newsreleases/national/gdp/2011/gdp4q10_3rd.htm, accessed

November 15, 2013. 
Von Bülow, Marisa

2010 Building Transnational Networks: Civil Society and the Politics of Trade in the Americas. Cambridge University Press.

Walton, A.A.

2004 "Mining a Sacred Land." Human Rights Dialogue 2 (11): 24-25.

http://www.carnegiecouncil.org/resources/publications/dialogue/2_11/section_3/4459.html/

:pf_printable, accessed November 6, 2011

Warf, Barney, and John Grimes

1997 "Counterhegemonic Discourses and the Internet." Geographical Review 87 (2): 259274.

Weir, Peter

1982 The Year of Living Dangerously. (Film)

Wenger, Etienne

1998. Communities of Practice. Cambridge University Press: New York

Yoneyama, Lisa

1999 Hiroshima Traces: Time, Space, and the Dialectics of Memory. Berkeley and Los

Angeles: University of California Press.

Zhao, Shanyang, Sherri Grasmuck, and Jason Martin

2008 Identity Construction on Facebook: Digital Empowerment in Anchored Relationships.

Computers in Human Behavior 24(5): 1816-1836. 